\title{
Sacred Matter: Reflections on the Relationship of Karmic and Natural Causality in Jaina Philosophy
}

\author{
Peter Flügel
}

(SOAS)

\begin{abstract}
The article examines a fundamental problem in classical Jaina philosophy, namely, the ontological status of dead matter in the hylozoistic and at the same time dualistic Jaina worldview. This question is of particular interest in view of the widespread contemporary Jaina practice of venerating bone relics and stūpas of prominent saints. The main argument proposed in this article is, that, from a classical doctrinal point of view, bone relics of renowned ascetics are valuable for Jainas, if at all, because of their unique physical attributes, rather than the presumed presence of the deceased in the remains as posited in much of the extant literature on relic worship across cultures. The specific focus of the article are Jaina and nonJaina explanations of the qualities of special matter in terms of karmic and natural processes of transformation.
\end{abstract}

Keywords Ascetic body $\cdot$ Power $\cdot$ Sacred matter $\cdot$ Relics $\cdot$ Stūpas $\cdot$ Jaina karman theory $\cdot$ Theory of parin a ama . Theory of multiple causation · Principle of the excluded third $\cdot$ do-kiriyā $-v \bar{a} y a \cdot$ terāsiyā-vāya $\cdot$ cattara-bham.gā

This article is dedicated to Karel Werner. The research was in part funded by Arts and Humanities Research Council (AHRC) Fellowship AH/I002405/1. I am indebted to Ācārya Śubhacandra, and Muni Padmacandra (Jaymalgacch), and Ācārya Sun̄̄lsāgara, Muni Amodhakīrti, and Muni Amarakīrti (Digambara Ācārya Ādisāgara An̉kalīkara Paramparā) for their explanations of details of Jaina karman theory; and to Lance Cousins, Padmanabh S. Jaini, Kristi Wiley and J. Clifford Wright for their insightful comments on earlier versions of the text. 
This article is about heresy (mithyātva). ${ }^{1}$ It examines a fundamental problem in classical Jaina philosophy, namely, the ontological status of dead matter in the hylozoistic and at the same time dualistic Jaina worldview. This question is of particular interest in view of the widespread contemporary Jaina practice of venerating bone relics (asthi) and stūpas of prominent saints. ${ }^{2}$ Of the eight early doctrinal schisms (pravacana-nihnava) ${ }^{3}$ in the Niggantha (Jaina/Jain) tradition, mentioned in the Śvetāmbara texts Ṭhāṇa $17.140-142^{4}$ and Uvavāiya $\left(\mathrm{Uv}_{1}\right)$ 160, and described in Āvassayanijjutti ${ }^{5}\left(\bar{A} v N_{1}\right) 778-788$ and its commentaries, ${ }^{6}$ two will be of significance for the main argument proposed in this article, that, from a classical doctrinal point of view, bone relics of renowned ascetics are valuable for Jainas, if at all, because of their unique physical attributes, rather than the presumed presence of the deceased in the remains as posited in much of the extant literature on relic

\footnotetext{
${ }^{1}$ Prakrit (Pk.) micchatta. In the Prakrit texts, the short form ditthi is often used, from micchā-ditthi, (someone who holds a) wrong-view. Sometimes also micchä is used (Jaini 2007, p. 165). In the canon, non-Jaina heresies are discussed in particular in the Sūyagaḍa (Sūy.), in the Viyāhapannatti (Bhagavaī) (Viy.) and in form of a list of Brāhmanical texts, in the Namdī $\left(\mathrm{NS}_{1,2}\right) 67=\mathrm{NS}_{3}$ 77. See Schrader (1902), Folkert (1993), Ohira (1994, pp. 162-164), and Bollée (1999, 2006). Folkert (1993, p. 296f.), compiled a comprehensive list of terms for heretics in the Suyyagada, labelled "non-Jainas", and pointed out that "[t]wo sorts of mithyādarśana are postulated, one that is inborn and one that comes from others" teachings" (ib., p. 295).

${ }^{2}$ Pk. pavayana-ninhava. For details, see Flügel (2008, 2010b). "Sacred matter" is in the following used as an observer's gloss for "dead-" or "insentient matter" associated with the bodies of Jaina ascetics. See Jaini (1985, p. 90): "Only ascetics ... are truly auspicious".

3 Also Pk. ninhaga, ninhaya. Sk. nihnava.

${ }^{4}$ The Thāna is a quasi-encyclopaedic canonical (siddhānta) Śvetāmbara text.

${ }^{5}$ On the composite structure and history of the ĀvN, an important Śvetāmbara text going back to the 1st century C.E., traditionally attributed to Bhādrabahu II, whose canonical status is disputed because it was compiled much later, see Leumann (1934, p. 28). The present article focuses mainly on Śvetāmbara sources. However, a brief survey of Digambara texts points to evidence for similar conceptions. See infra the discussion of $\mathrm{SaSi}_{1} 357$ for example.

${ }^{6}$ Leumann $(1885,91 \mathrm{ff} ., 1934$, p. 46$)$ refers to the following early Prakrit sources: Thāna ${ }_{1} 7.140-142$ (list of names of the officially seven schisms, founders, places) and in prose Viy. 9.33 (the first schism of Jamāli; a text dated by Ohira $(1994$, p. 148) to the fifth century); Non-canonical: in verse Āvaśyaka 8.56-100 (additional dates of origin, narration of reasons, and final observations) $=\overline{\mathrm{A}} v \mathrm{~N}_{1} 778-788$ and anonymous Mūlabhāṣya 126-148; Jinabhadra's sixth to seventh century Visesāvassayabhāsa (ViĀvB) III \& IV and in Jaina Māhārāșțī Prakrit and Sanskrit prose Haribhadra's eighth century Āvaśyakavṛtti (or tịkā) (ĀV) in $\bar{A} v N_{1}$ II, pp. 312-328. Leumann's (1885, p. 97) review of the sources does not refer to the $\bar{A}$ vassayacunni $(\bar{A} v C)$ which has been attributed to Ācārya Jinadāsagani Mahattara (593-693 C.E.) and Uttarajjhāyananijjutti (UttN) 165-178. See Balbir (1993, pp. 67, 146) on parallels in Hemacandra's twelfth century Trișaștiśalākāpurușacaritra (TŚPC) 10.8.28-108 (Johnson 1931-1962 VI, pp. 193-198). The ĀvN mentions not only the seven heresies but also (according to Leumann 1885, p. 92 with help of interpolations) the more recent heresy of the Botikas (Digambaras) which alone led to a sectarian schism persisting until today. Only the first and the eighth schism in particular attracted further attention in the academic literature. On the heresy of Jamāli, see Deleu (1970), Bronkhorst (2003), Dundas (2006). The rebirth prospects of the seven nihnava-käriyas, who are after all reborn in heaven, are outlined in $\mathrm{Uv}_{1}$ 160. Leumann's 1885 German rendition of the ĀvN passage relies on the text transmitted in the commentary of Śāntisūri.
} 
worship across cultures. ${ }^{7}$ The two early schisms are the fifth and the sixth, which, according to the ĀvN, took place 228 and 544 years after Vaddhamāna "Mahāvīra's" death. According to S. Ohira's (1994, p. 227f.) reconstruction of the history of ideas in early Jainism, the debated philosophical questions emerged in the middle and late-canonical periods, sometime between the first century B.C.E. and the fourth century C.E. Her account broadly matches the traditional dates if the nirvāna date of Vaddhamāna is brought forward to 395 B.C.E., as proposed by K.R. Norman (1991/1993, p. 201). ${ }^{8}$

The heretical ideology attributed to Ajja ${ }^{9}$ Ganga, who is said to have caused the fifth schism, is known as the "doctrine of two actions" (do-kiriyā-vāya).${ }^{10}$ In the Āvaśyakavrttti, a commentary on the Āvassayanijjutti composed by Ācārya Haribhadra in the eighth century in mixed Prakrit and Sanskrit prose, the following information is given. ${ }^{11}$ Ajja Ganga lived in the town Ullagătîra at the river Ullagā. His guru Dhanagutta lived on the other side of the river. To venerate his teacher, Ajja Ganga once waded in the autumn midday heat through the cool waters to reach the other side of the river. Because of the simultaneous sensation of the cold water and of the hot sun, he remembered the teaching of the scriptures, that "only one sensation can be experienced at the same time, either a cold or a hot sensation", ${ }^{12}$ which seemed to contradict his experience. He discussed the matter with Dhanagutta, who simply dismissed his doubts, and was subsequently forced to leave the order, because was not prepared to change his mind. Sometime after his expulsion, Ganga was however reconverted by the polite snake god Nāga of Rāyagiha, who angrily threatened him with death, because of his deviation from Vaddhamāna's beloved teaching. No explanation of the reasons for the reconversion is given.

\footnotetext{
${ }^{7}$ See Oldenberg (1894/1917: 586, n. 1) for the Vedic conception "daß in den Gebeinen der Tote gegenwärtig ist [that the deceased is present in the bones]", and attempts to protect the bones from the cremation fire by covering the corpse with body-parts of a cow (ib., p. 577). For a review, see Flügel (2010b, pp. 468-482). The fact that in practice many Jains have different attitudes (see for instance the ceremonial 'eye-opening' on Jina statues in the image-worshipping traditions) is not a philosophical but an anthropological issue.

${ }^{8}$ According to the Śvetāmbara tradition, Vaddhamāna lived 599-527 B.C.E. The Digambars settled for 587-510 B.C.E.

${ }^{9}$ S. $\bar{a} r y a$, venerable. In the following the original Prakrit is used.

${ }^{10}$ Sk. dvi-kriyā-vāda, but in the literature since Haribhadra's ĀvN 780 ("gaingāt dvaikriyāh") generally: dvaikriya-vāda.

${ }^{11}$ Supplementary to $\overline{\mathrm{A}} v \mathrm{~N}_{1} 780$, Mūlabhāsya $133-134$, p. 317. The do-kiriya doctrine is also discussed in the universally accepted parts of the canon (without mentioning the name Ganga), in Viy ${ }_{1}$ 1.9.3 (98a), 1.10.2 (106a), 2.5.1 (131a), 5.3.1 (214a), 6.10.3 (285b). Bhatt (1983, pp. 113, 111) placed it in the second of three main textual layers and Ohira (1994, p. 227) located the underlying "kriyā-vedanā problem" (experience of the fruition of karman) of the first three texts in the third to fourth of her scheme of canonical stages (1st century B.C.E.-4th century C.E.) and the last three texts in the fourth to fifth (4th century C.E.).

${ }^{12}$ sutte bhaniyam jahā egā kiriyā vedijjai - sìtā usiṇā vā (ĀvV 134).
} 
Maybe Ganga realised, after all, that feelings of love and hate cannot coexist at the same time. ${ }^{13}$

The sixth schism, the heresy of Chalu(g)a, is briefly listed in Țhāna ${ }_{1} 7.141$ and in $\bar{A} v N_{1}$ 780. According to Haribhadra's commentary on Mūlabhāṣya 140, he was the author of the Vaisesiyasutta (Vaiśeșikasūtra) (elsewhere know as Kanāda) ${ }^{14}$ and the first to propose the "doctrine of the triad" (terāsiyā-vāya). ${ }^{15}$ In contrast to the other

13 The Digambara mystic Kundakunda, who has been placed by most scholars in the second century C.E., refuted the dokiriyā doctrine in chapter three of his Samayasāra vv. 85-86:

jadi poggalakammaminam kuvvadi tạ̣ ceva vedayadi ādā |

dokiriyāvāadittam pasajadi so jiṇ̄vamadam \|85||

jahā du attabhāvam poggalabhāvam ca dovi kuvvaṃti |

tena du micchādițthī dokiriyāvādino hoṃti $\|86\|$

85. If the $\bar{A} t m \bar{a}$ or Self produces these Karmic materials (operating as upadānā kartā or substantive cause) and enjoys the consequences thereof in the same manner, it will lead to the doctrine of a single cause producing two different effects, which will be in conflict with the Jaina faith.

86. Because they make the modifications of Self as well as modifications of matter to be effects of the same identical $\bar{A} t m \bar{a}$ or the Self (operating as upādāna cause) the believers in that doctrine of causation (which derives the conflicting effects from the same source), are said to be of erroneous faith" (English rendition by Chakravarti, in SS, p. 73f.).

On this passage, and others, see Upadhye (1935, p. xlviii), who restated that both the Śvetāmbara and the Digambara traditions reject "the tenent that the soul can be the agent of its psychic states and also of karmic modifications". Chakravarti (1950/1989), in SS: 73f., pointed out that Kundakunda invoked the two-truth theory for making the point that from the conventional point of view the soul is the cause of its own karmas, but not from the transcendental point of view, because of the strict Jaina dualism. Cf. Johnson (1995, p. 260f).

Mālvaniyā (1971, p. 418) summarised Malayagiri's commentary on the question of the possibility of simultaneous hot-cold feeling which is also mentioned in the canonical P 36, saying that "though the concerened cognitions take place alternately, their alternation being quick and speedy is not noticed by us; and from this standpoint only the Sūtra considers the cognitions of hotness and coldness to be simultaneous".

14 Jacobi (1895, pp. xxxvii-xxxviii) argued that "Rôhagupta did not invent, but only adopted the Vaisêshika philosophy to support his schismatic views". He etymologically linked Kanāda, "crow-eater, owl", whose system was nicknamed "Aulûkya Darsana", with "Rôhagupta's second name, Khuluya", which seems to allude to ulūka," owl", hence (implausibly) furnishing Sk. Saḍulukka, "six owl", for Chalu(g)a, as suggested already by Haribhadra (ĀvN 780) and echoed by all Prakrit dictionaries.

15 Sk. trirāśs-vāda, but in the literature since Haribhadra's ĀvN 780 ("șadulūkāt trairāsikā-nāmutpattih") generally: trairāsika-vāda, "doctrine of the three heaps or categories". A school of this name is also mentioned in the Namdī $\left(\mathrm{NS}_{4}\right) 77$ (No.12) \& 104 (No. 7), but without reference to Rohagutta. The equivalent passages of $\mathrm{NS}_{4} 77, \mathrm{NS}_{1} 72$ and $\mathrm{NS}_{2,3}$ 67, refer to vesiyam instead of tesiyam and terāsiam, and the equivalent passages of $\mathrm{NS}_{4}$ 104-NS $106 \mathrm{f}$., $\mathrm{NS}_{2,3}$ 101f., refer to tigunam as "terāsiyāim" rather than to keubhūaṃ. Punyavijaya, Mālvaniyā and Bhojak (1968, pp. 107-109) have discussed the textual history of the "corrupt reading tesiyam" and rarely (apparently following the edition of Sāgarānandasūri) terāsiyam instead of vesiyam, which they interpret as "vaiśeșikam". They come to the conclusion that the Sthānakavāsī editions by Hastīmal and by Ghāsīāl are responsible for the view that both passages (not just the second) refer to the $\bar{A} j \overline{1} v i k a s$ :

The term vesiya was turned into tesiya by the copyist reading ta instead of va; then tesiyam became terāsiyam; afterwards this terāsiyam got equated with trairāśika; and at last on the basis of the commentary on sūtra 107 it was written that by this term (sūtra 72 [1]) the commentator [Malayagiri] means [the] Ājīvika school founded by Gośālaka [rather than the Terāsiya school] (ib., p. 108f.). 
Nigganthas, who favoured the ontological dyad of life (jīva) and non-life (ajīva), he posited three rather than two fundamental categories of reality: life (jīva), non-life $(a j \bar{\imath} v a)$, and quasi-life (nojīva). ${ }^{16}$ The third category designates either an intermediary or mixed state of entities that appear to be temporarily both alive and notalive, or an ontological entity that is neither jivva nor ajiv $a .{ }^{17}$ While the first interpretation was favoured by Leumann (1885, p. 123) and Mehta and Chandra (1970 II, p. 646), the second interpretation is chosen here. ${ }^{18}$ In the more detailed accounts in Mūlabhāṣya $135-140^{19}$ and Haribhadra's commentary, the schism is labelled "heresy of Rohagutta", a monk who in later Jaina literature is identified with Chaluga. ${ }^{20}$ Rohagutta once felt the need to challenge a knowledgeable wandering ascetic commonly known as Pottasāla ("Belly-Tree" ${ }^{21}$ or "Drum-Stick"), who was so full of himself that he girded himself with a copper wire, lest his dress would burst because of the abundance of his knowledge, and carried a branch of the Jambu tree (jambu-dālam) to indicate that on this Jambu island, at the centre of the middle world, no-one could match his scholarship. The debate was held at the court of king

\footnotetext{
${ }^{16}$ Leumann $(1885$, p. 118, n. 8) translated nojī $\bar{a}$ ambiguously as "halblebende" or "half-living" beings: "no hat im Gegensatz zu $a$ in Composition nicht privativen, sondern prohibitiven Sinn, und so bezeichnet nojivâ Wesen, die obwohl eigentlich jîva, nicht dazu gerechnet werden dürfen, sei es nun wegen Verstümmelung oder anderer Ursachen". In modern Jaina commentaries no- is usually translated as "quasi-", which is somewhat equivocal. Monier-Williams (1899/1986, p. 571) states that Sanskrit no stands "in later language" for $n a$, "not". Pischel (1900/1999, § 170, p. 151) points to cases where Prakrit no is the result of na undergoing sandhi with the initial vowel of the next word, which could lend support to the interpretation no-ajīva, "not-non-life", or rather no-jī $\bar{j} \bar{j} \bar{i} v a$, "not-life-non-life", that is "neither life nor non-life", as the intended meaning. Seth (1928/1986, p. 422) explains nojiv $a$ in general terms as either an "insubstantial" third category that is different from jiv $a$ and $a j \bar{i} v a$, or as a synonym of ajiv $a$ or of nirjīva. In his commentary, Haribhadra ( $\overline{\mathrm{AvN}} \mathrm{N}_{1}$ II: 320) refers to the the "four points of view" of Jaina logic, the cattara-bhamga a , which Leumann $(1885$, p. 123 n. 1) interprets as a "later phase of the doctrine of the triad": "in der eigentlichen Erzählung vom Schism war ... noch keine Hindeutung darauf vorhanden, dass auch den nojîvâ eine Negation gegenübergestellt werden sollte". Hence, according to Leumann, Rohagutta must have favoured the third perspective of the tetras-doctrine ("both-and") rather than the fourth ("neither-nor"). In favour of his interpretation speaks that, even in early texts, the fourth alternative is generally acceptable in Jaina logic and should not have caused a controversy on logical grounds (see Flügel 2010a, pp. 155-180). Yet, it would certainly have been controversial if interpreted ontologically as a third fundamental substance. Notably, apart from jiva all other astikâyas are treated as sub-categories of ajīva. See footnote 18.
}

${ }^{17}$ Mehta and Chandra (1970 I, p. 347) mention a doctrine, also labelled terāsiya, which was in the Jaina commentaries attributed to the Ājīiviya (Sk. Ājīivika) Gosāla, who apparently believed "that there are three states of souls, viz., bound, liberated and redefiled (after liberation)" (citing Nandisūtracūrṇi p. 73; Nandisūtravṛtti of Haribhadra, p. 87; Nandisūtravrttti of Malayagiri, p. 239; Samavāyāngavritti of Abhayadeva, pp. 42, 130; Sūtrakrtāngavrtti of Śīānika, p. 393). See footnote 15.

In a different context, Jaini (1979, p. 97) identifies another "third category": Sk. arūpi-ajīva, referring to the substances (dravya) space, time, movement, rest which have neither form nor life. Technically, however, it is a sub-category of ajivia and not a third category. See Glasenapp (1925, p. 152). See infra. For the same see also P. S. Jain (1999, p. 31)

${ }^{18} \mathrm{I}$ am grateful to J. C. Wright for convincing me of the plausibility of the no'jīv $\bar{a}=n o-j \bar{j} \bar{a} j \bar{j} \bar{v} \bar{a}$, "neither jīva nor ajīva”, interpretation. For the same see also P.S. Jain (1999: 31).

19 ĀvN $N_{1}$ Mūlabhāsya 135-140, pp. 317-322. For further textual sources, see Mehta and Chandra (1970 II, p. 481).

${ }^{20}$ For instance by Muni Nathmal (= Ācārya Mahāprajña) in his Hindī commentary on Ṭhāṇa ${ }_{1} 7.140-142$ (p. 781).

${ }^{21}$ Leumann (1885, p. 117): "Kleid-Ast". 
Balasiri of Aṃtaramjiyā. Because Potțasāla anticipated Rohagutta's arguments in favour of the Jaina dyad of jīva and $a j \bar{\imath} v a$, he argued the Jaina case himself, and thereby forced Rohagutta to defend the triad of jivva, ajīva and nojivva. ${ }^{22}$ The contest was finally won by Rohagutta, not through argument, but through the magical power of his rayaharana, the whisk brush used by the itinerant monk or nun to gently remove small living beings away from their path, which is the main insignium of the Jaina ascetics. Prior to the contest, the rayaharana had been charged with mantras by his preceptor Sirigutta, who was aware of the seven magical powers which Potṭasāla was known to employ in debates whose argument he had lost. Sirigutta therefore gave Rohagutta seven forms of counter magic. When Potțasāla's seventh form of magic, the mockingbird magic, was defeated with the "ulāva" counter magic, Pottasāla, in desperation, sent a she-ass. But he was beaten back with the rayaharana. After his victory Rohagutta continued to favour the terāsiya doctrine. According to Haribhadra, he even composed the Vaiśesikasūtra, a text whose decisive influence on the formation of classical Jaina atomism was explained in this way as a Jaina creation. Finally, he was defeated in a public debate in the royal court by his old teacher Sirigutta, who finally simply asked him to go to the market (which Jaina monks should not do) and to bring him living, dead and quasi-living things. When Rohagutta requested for quasi-living things he was only presented with dead objects. $^{23}$

The morale of both stories is of course that Vaddhamāna was right. There should be no conceptual confusion of the fundamental ontological dualism informing his teachings, especially not in the context of epistemology and logic. ${ }^{24}$ Although at first sight the heresies of Ganga and Rohagutta appear to be entirely different (associated with $\overline{\mathrm{A}} \mathrm{j} \overline{\mathrm{v}} \mathrm{ika} \mathrm{C}^{25}$ and Vaiśeșika philosophies), both featured "category mistakes" and by elevating ambiguity from a vice to a virtue threatened the very

\footnotetext{
22 ĀvN $\mathrm{N}_{1}$ II: 319f. (Commentary to Mūlabhāșya 138): “do rāsī, tam jahā - jīvā ya ajīvā ya, ... tinni rāsī

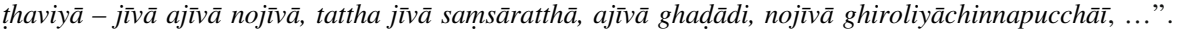
Following this passage, the classical example of "neither life nor non-life" in Jaina texts is the tail of a lizard which still moves for a while even after having been severed from the body.

23 ĀvN $\mathrm{N}_{1}$ II: 319: "āneha jīve ajūve nojīve ya, tāhe devayāe jivā ajīvā ya dinnnā, nojīvā natthi, evam-ādicoyālasaenạm pucchānạ̣ niggahio.

${ }^{24}$ See Flügel (2010, p. 155-162) on the Jaina critique of "partially true speech" (sacca-mosā-bhāsā), including category mistakes.

${ }^{25}$ See Viy. V.3 and ViyBh 5.57-58. Basham (1951, pp. 175-181, 274f.) cites the relevant Śvetāmbara

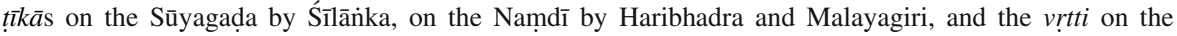
Samavāya by Abhayadeva which either identify the Ājīvikas with the Jaina trirâsívāadins (like Hoernle 1908, p. 262) or describe them as another example of a sect propagating this doctrine. A similar position, held by the Buddhist Rājagiriyas and Siddhatthikas who in contrast to the Theravādins argued that an act such as a gift can have an effect here and elsewhere, is documented in the Kathāvatthu (KV) VII.6. McDermott (1975, p. 431) noted that the argument was used to bolster the disputed doctrine of "merit transfer".
} 
foundation of the teachings attributed to Mahāvīra in the classical canonical texts. ${ }^{26}$ Another inference the reader/hearer is invited to draw is that dialectics and magical power may win arguments in scholastic debates, but will not buy real things in the markets.

\section{Ascetic Power and Karman}

The extraordinary powers of Jaina ascetics, and of their relics, are attested by numerous Jaina sources. Particular prominence was given to them in texts from the middle and late canonical periods onwards, at a time when the Jaina mendicants faced strong competition from Buddhist and Brāhmanical opponents and classical Jaina doctrine was systematised. ${ }^{27}$ The following investigation draws mainly on the Viyāhapannatti (Viy.), the "Exposition of Explanations", the largest and most unsystematic text of the Śvetāmbara canon, compiled over a period of about six hundred years, in which "Jaina theoreticians" seemed to have "freely experimented to formulate novel ideas" (Ohira 1994, p. 232). Many of these ideas are labelled "heretical" (annautthiya) ${ }^{28}$ in the text and the commentaries, and demonstrated to be incompatible with Mahāvīra's teaching. Others were assimilated by Jaina philosophy at a later stage. In Deleu's (1987-1988, p. 178) analysis, the annautthiya-texts "form the backbone of the Viy." Most of the heresies are not named. An exception is the heresy of Jamāli, the first of the seven early schisms. Variants of the dokiriya $\bar{a}$ doctrine are also discussed, but Ârya Ganga is nowhere mentioned.

According to classical Jaina ontology and mythology, formulated in the later accretions of the Viyāhapannatti, and in the secondary pannatti texts as well as other late- or post-canonical scriptures, ${ }^{29}$ ascetic powers, iddhi, ${ }^{30}$ laddhi, siddhi, and

\footnotetext{
${ }^{26}$ Ohira (1994, p. 237) argued that the main thrust of this period of theorisation (middle and late canonical period, especially third Vallabhī council) was "was to proclaim and authorize that the doctrine of jīva-ajīva constitutes the cardinal doctrinal system for all the Jainas". However, she emphasized that ideas of many "heresies" were later incorporated and distinguishes between two types of ninhavas: those who present a clear cut Jaina position and those (like the fifth and the sixth) which do not (ib., p. 164). ${ }^{27}$ Ohira (1994, pp. 98, 161f.) places all classical texts detailing the miraculous power of ascetics in the 4th-5th century C.E. See supra.

${ }^{28}$ Sk. anyatīrthika.

${ }^{29}$ On seconday pannatti-texts, see Schubring (1926, p. 10) and Deleu (1970, p. 31). The main systematic text of classical Jainism is Umāsvāti's Sanskrit Tattvārthasūtra (TS), usually dated fourth century C.E. In parts it builds on earlier segments of the Viy.

${ }^{30}$ Deleu (1987-1988, p. 173f.) argued that there is "a studied logical sequence" connecting the dispersed iddhi texts associated with gods Viy. II.8 (Camara), X.6 (Sakka), XVI.9 (Bali), XVII.5 (İsāṇa), and associated with the logapālas of Sakka and İsana III.7-8, IV.1-8, and on the wives and abodes of different types of gods X.5, XIX.7. According to him (and Bhatt and Ohira), the key ontological sections (uddesa), which will be discussed in this article, are also late accretions: II.10, XIII.4, XI.10 (atthikāya, $\log a$, etc.), VIII.1 (poggala-parināma), VIII.9 (bandha).
} 
physical strength (bala), ${ }^{31}$ are generated by sustained austerities (tava), whose positive effects ${ }^{32}$ are encoded and stored in distinct sets (pagadi) of karmic particles (kamma-poggala) of varying subtleness (suhuma). ${ }^{33}$ The atomistic notion of karmic matter was an innnovation at the time. ${ }^{34}$ It differentiates classical from early voluntaristic Jaina karman theories. ${ }^{35}$ Like the seeds of a plant, a karman-particle embodies action in potentia $(s a t t \bar{a}){ }^{36}$ This potential comes to fruition either naturally (udaya) ${ }^{37}$ under specific conditions and within a karmically determined time frame, ${ }^{38}$ or by being ripened prematurely (udīraña $)$ through deliberate

31 See Flügel (Forthcoming a) on Jaina concepts of power. The cited terms are the labels used by the lists
of ascetic powers in the texts themselves. More terms for power, such as pabhāva (S. prabhāva), will be
introduced at specific junctures of the following discussion. Frauwallner (1953/1997 I: 138f., 142f., II:
$255 \mathrm{n} .346$ ) points to the resemblance with "the wonder-powers (rddhiprabhedāh) which are enumerated
by older Buddhism" and Yoga literature; stressing that in "Jain understanding, the individual steps of
meditation are connected with the attainment of the different wonder-powers (riddhih, P. iddhi)" as in
Buddhist (ib. I, p. 142) and possibly older Brahmanical views (ib. I, p. 204), including the theory of
ascetically produced secondary spirit bodies (ib. I, p. 142).

32 In later Jaina literature, asceticism is said to have two effects: it destroys accumulated karman (nirjarā) and it reduces demerit ( refined karmic particles, through a variety of karmic processes.

$33 \mathrm{Viy}_{3} 1.19$, cf. Viy 1.4 (24b uses the opposition fine (anu) and gross (bāyara).

34 However, there are precursors and parallel developments in Brāhmanical philosophy (Potter 1980, 2001, p. 235 on karmāśaya) and literature (Dundas 2002, p. 290, n. 25) and parallels in contemporary (Tamil) folklore (Daniel 1987, p. 212). Cf. Flügel (Forthcoming b).

35 On voluntaristic or teleological karman theories, see Bronkhorst (2000). On the contrast between voluntaristic and system-theories of karman, see Flügel (2008) on L.C. Jain's work.

36 See Schubring $(1935 / 2000 \S 85$, p. 176) on the earlier term $\bar{a} b \bar{a} h \bar{a}$ (Sk. $\bar{a} b \bar{a} d h \bar{a})$, literally pain or oppressive trouble.

37 Cf. Potter's (1964, p. 44) analogy between the principle of karman and quasi naturalistic habits. Cf. also Bourdieu (1980/1992), who did not cross-reference the concept karman to his theory of habitus.

38 Classical (Śvetāmbara) Jaina karman theory distinguishes four basic attributes of karman:

1. effect (prakrti),

2. duration (sthiti),

3. intensity (rasa or anubhāva), and

4. quantity (of space units) (pradeśa).

Modes of prakrti are:

(a) bondage (of certain types of karman) (bandha),

(b) latent / potential (existence of karman) (sattā), and

(c) realisation (udaya):

(i) premature fruition (udīrañā), and

(ii) transformation of one type of karman into another (samkrama).

The principal modes of sthiti and rasa are:

(a) quantitative enlargement (apavartanā), and

(b) reduction (udvartanā).

These processes are largely depending on the intensity of the passions (kașāya). Determinism is prevented by positing mechanisms of qualitative transformation of the effects of karman, such as the transformation of one type of karman into another (samkrama), and automatic (self) transformation (parināma) through asceticism. See Glasenapp (1915/1942, pp. 28-39). 
ascetic exertions, ${ }^{39}$ in mind, speech and body. ${ }^{40}$ The doctrine of karman can thus be interpreted as a theory of power. Karmic particles encode specific qualities and potentialities of action (karman). Yet, they are not the source of karmic power. The specific potential stored in karmic particles is said to be predicated on the innate infinite energy (vīriya) of the soul $(j \bar{\imath} v a),{ }^{41}$ which the karmic process (particleaction) channels into specific forms and hence limits and perverts at the same time. ${ }^{42}$

In Viy $1.3 .5(56 \mathrm{~b})=\mathrm{Viy}_{3,4,8}$ 1.3.144 energy is said to be produced by the body which in turn is produced by the soul (the sequence of causality is: jīva> sarīra $>$ vīriya $>$ joa $>$ pamāda $>$ kam $k$ ha $\bar{a}$-mohanijja-kamma; soul>body $>$ energy $>$ activ-

\footnotetext{
39 On karana, the instrumental forces of the embodied soul, mind, speech, body and karman (manakarane, vai-karane, kāya-karane, kamma-karane), see $\mathrm{Viy}_{3} 6.1 .5$, cf. $\mathrm{Viy}_{1} 6.1 .2$ (251b).

40 The process, here starting with the transformation of already attracted and bound matter, has been summarised already in one of the oldest mnemonic verses of the Viy. following $\mathrm{Viy}_{3} 1_{1} 18$ :

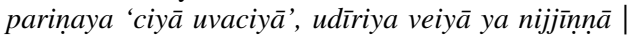

ekkekkammi padammi, cauvvihā poggalā homti $\|$

There are four queries concerning each of the following expressions related to matter: transformed [parinamai], stored up [cinai], profusely stored up [uvacinai], prematurely brought to rise [udīrei], experienced [veei], and worn off [nijjarei]

(Viy $_{8} 1.18$ Samgahan̄i Gāhā 1, cf. Viy 1 1.1.3 [23a]).
}

See Glasenapp (1915/1942, pp. 19, 28-39) and Schubring (1935/2000, §§ 84-86) on the difference between udaya (not mentioned in the gāthā) und udīraña, with added historical notes.

Discussions on similar concepts in Buddhism are recorded in the Kathāvatthu (KV). See McDermott (1975, p. 430, etc.) In the Brāhmanical tradition, the Pūrvamīmāmsāa concept of apūrva, impersonal "potency", and the Vaiśeșika concept of adrșța, the "invisible" cosmic force relating to karman, were somewhat similarly proposed to explain storable causal potencies which attach to the agent of an (sacrificial) action $(k r i y \bar{a})$, and hence account for the efficacy and power of sacrifices, as Halbfass (1992, p. 298ff). showed. He emphasized that "adrsțta seems to function primarily as a principle of physicalistic, naturalistic explanation, and its ethical and soteriological implications remain at least very obscure" (ib., p. 315). On the influence of the concept of adrșța on the Jaina concepts of dharma and adharma, condition of movement and rest, see Ohira (1994, p. 105f.).

41 See Glasenapp (1915/1942, p. 45) on vīrya (Pk. vīriya) as an "innate" quality of the soul:

The soul has vīrya 'energy' 'infinite capacities of activity'. This innate quality manifests itself only if the jīva is free from all karman-matter. As long as the virya-antarāya- $k$ is operating, the virrya is, although not completely eliminated, nevertheless exceedingly restricted. It does not manifest itself spontaneously, as is the case with released souls, but it is bound to matter. It needs an organ as 'accompanying cause' (sahakārikārana), in order to be able to act; it needs the medium of the body, the organ of speech and manas, in order to manifest itself. This form of virrya, bound to matter, is called yoga (activity) (ib.).

Glasenapp (1915/1942, p. 19), Schubring (1935/2000, § 83, p. 172) and Deleu (1970, p. 84) (on Viy 1.8 [94a-b]) interpreted viriya predominately as 'will' or 'will-power'. Attributes of the innate will-power (purușārtha) of the soul are detailed in $\mathrm{Viy}_{1} 1.3 .5(56 \mathrm{~b})=\mathrm{Viy}_{3,4,8}$ 1.3.146 in form of a list of terms designating kindred qualities, "synonyms" according to Schubring, which in Țhāna 11.44 are said to become manifest only one at a time: uț̣hāna, kamma, bāla, vīriya, purisakkāra-parakkama (impetus, action, physical strength, mental energy, self-exertion, capacity of accomplishment). According to the Namdīcunni 104, the power (vīriya) of inanimate entities was apparently a topic of the "lost" third Pūrva (Tulsī \& Mahāprajña 2009, p. 316). Viy 1.4 .2 (63b) distinguishes the wise and foolish use of power. See also $\mathrm{Utt}_{1}$ 28.11. See further Frauwallner (1953/1997 I: 200, 209f.) on the peculiar active nature of souls in Jainism.

42 On the process of channelling infinite into limited power, see Tatia's (1994, p. 151) summary of Umāsvātī's autocommentary and Pūjyapāda's commentary on $\mathrm{TS}_{1}$ 6.1.-2. 
ity $>$ carelessness $>$ karman of view-deluding inclination). Yet, in the commentaries such as ViyVṛ 1.3.146 and in Thānana 1.44 it is interpreted as an attribute of the soul. In order to solve the conundrum, inactive (akarana) and active (sakarana) forms of energy, associated with soul and body respectively, were distinguished (ViyVr1.3.143f., cf. ViyBh 1.3.140-146). Hence, vitriya is not merely conceived as presupposition of a particular action, but as a homogenous meta-quality, ${ }^{43}$ presupposed by all actions. ${ }^{44}$ Not only does it energise, but also transforms, suppresses and destroys all forms of karman that inhibit the soul's path towards self-liberation (mokkha-magga). The efficacy of the path of purification through processes of refinement and depletion of karman depends on the degree to which the powerobstructing karman (vîriya-amtarāya-kamma) is suppressed and removed. Suppression (uvasama), destruction (khava), and transformation of one karman into another (samkama) are the elementary purging mechanisms that can be wilfully activated by the soul ${ }^{45}$ through ascetic practice, ${ }^{46}$ including meditation. Together with consciousness (uvaoga), the main quality of the soul, virya represents the quality of free will ${ }^{47}$ which distinguishes Jaina karman theory from deterministic interpretations of karman, such as the Ājīivika doctrine or Śankara's insistence on God as the latent source of karmic power. ${ }^{48}$ Virya is therefore often translated as "will-power". It is only because of will-power that the ascetic is able to perform austerities to eliminate karman (path of liberation) and to transforms gross into subtle karman (path of purification). ${ }^{49}$ A peculiar aspect of the Jaina (and Buddhist) theory of karmic power is that power and purity of an individual are not opposites, as in comparable Hindu conceptions, but two sides of the same coin, as indicated by Dumont (1980, pp. 215f., 300) and Tambiah (1977, p. 43). Through asceticism,

\footnotetext{
43 Jaini (1979, p. 105f.).

44 The compound vīriya-laddhi, for instance, designates embodied power, not vīriya as such. Cf. Viy 5 3.6.

45 The soul itself is seen as active in Jaina philosophy. See for instance Glasenapp (1915/1942, p. 45). In contrast to Sāmkhya philosophy, for instance, Jaina teaching is therefore referred to as kriyāvāda in the canon:
}

Of one's own accord one makes [karman] effective (udīrei) and one repents (garahai), checks (samvarai), suppresses (uvasāmei), experiences (veei) an annihilates (nijjarei) it by an effort of one's own will (vīriya) (Viy 1 1.3.6 [56b], rendered into English by Deleu 1970, p. 78).

However, Viy 14.10 (657a) and P 22 explicitly state that, in contrast to the still embodied kevalin, the siddha, or liberated soul, does not act, it is anutthāna (S. anusthāna or anutthāna), because it has no will or energy. See Deleu (1970, p. 213).

46 This does not mean that an exact prediction of the result of an act of asceticism can be given by a nonomniscient being: "It may well be said that the connections between action and result which Jainas set forth often have a rather arbitrary feelingabout them" (Jaini 1979, p. 116).

47 See Viy ${ }_{1}$ 2.10.c (149a).

48 On Śankara's interpretation in his Śan்karabhāṣya, on Brahmasūtra 3.2.38-41, see Sikdar (1987, p. 97).

49 Tabulations of on-to-one correlations between ascetic actions and karmic consequences (which would be hard to justify) do not exist. It is thought that both consequences are produced at the same time by asceticism. 
karmic potential is purified and strengthened at the same time. These processes of transformation work both on the physical and mental plane and also at the level of unconscious or automatic actions. The texts explain, for instance, that the natural fruition (udaya) of karman manifests itself in painful physical as well as mental experiences (veyanāa) of karman. According to Ohira (1994, p. 195), referring to Viy. 1.2 and 16.2, this shows that "[u]daya and vedana express the same phenomenon by the different agents, i.e. karma and the [embodied] soul".50

Power as a generalised potential to act is thus conceptualised as a combination of universal and specific qualities, of free will or raw energy of the embodied soul conditioned by karmic constraints. 'Raw power' is, as it were, domesticated by the two-tiered symbolism of this model, which constitutes karman as a system. In system-theoretical terms it is stabilised by a 'double-coding' of the concept of potentiality as virrya and as latent karman, that is, as the potential to act in general and in particular form. ${ }^{51}$ If one of the two components of karmically encoded power is removed, the potential to act disappears. The pure or liberated soul, thought to be active in itself, cannot act in the material world, ${ }^{52}$ because it is disembodied and without a specific intentional object outside itself, and karmic particles disconnected

\footnotetext{
${ }^{50}$ Compare the Buddhist debates on kamma-vipāka, in KV VIII.9 for instance; and Halbfass (1991/1992, p. 299) on Śankkara's Advaita Vedānta, where "duhkha and sukha themselves have objective as well as subjective implications".

${ }^{51}$ Cf. Luhmann (1975/1979, pp. 34-36/129f). On the method and social function of double-coded binary oppositions as generalised symbolical media, see Luhmann (1975/1979, pp. 31ff./27ff.), and infra. Notably, vīrya and karman do not represent 'two ideals' of power in Jainism (cf. Cort 1991a). An interesting question for future research is the investigation of different forms of secondary or tertiary coding in Jaina sectarian traditions.

52 This applies already to the last stage of embodied existence before the liberation of an omniscient being: "The holy man has then become an a-yogi-kevalin, and possesses henceforth, into all eternity, the infinite vīrya, bound to no organ, completely withdrawn from the influence of matter" (Glasenapp 1915/ 1942, p. 46). The "undifferentiated cognition and the [material] power of the jīva has disappeared" (ib., p. 90).
} 
from an external source of energy cannot perpetuate themselves and disintegrate into particles of inanimate matter. ${ }^{53}$

\section{Objectified Ascetic Power}

The special status of Jaina ascetics, explained by classical karman theory, is highlighted in Jaina narrative literature by the fact that in their case alone even body parts that are "out of place", 54 and usually create aversion, ${ }^{55}$ are praised for their attractive properties. The late- and post-canonical scriptures abound in lists and stories praising the astonishing qualities not only of living Jaina ascetics, but also of their body secretions and mortal remains, especially their hair, nails and bones, which do not quickly decompose, and of their objects of use. ${ }^{56}$ Benefitting others are the eight powers of healing (osahi-laddhi/iddhi), through ascetic touch, phlegm, secretions such as mucus and sweat, waste matter from the tongue, lip, teeth, nose and ear, urine and excrement, and everything that was in contact with the body of

\footnotetext{
53 There are subtle variations of the Jaina causal theory of power/action. Note the interpretation of "dual causality" in Digambara mysticism: Ācārya Kundakunda's SS 69-84, especially vv. 83-84 (only from the conventional point of view does it appear as if the soul causes transformations in poggala-kamma; tr. Schubring (1957, pp. 356-358); and the Laghutattvasphoța (LTS) of the tenth century Ācārya Amrtacandra, which builds on the work of Kundakunda (generally dated second century C.E.). In the words of the editor and translator Jaini (1978/2000):

Cause' is the designation for a complex situation; it involves self and other, i.e. of both material (upādāna) and efficient (nimitta) causes, which operate in mutual dependence (ib., p. 64).

Being a 'material' cause is the prerogative of the substance alone; that is, the substance (dravya) in one mode (paryāya) is the material 'cause' of the substance in its subsequent mode, which is thus the 'effect'. There can be neither an addition to nor a subtraction from this innate power of the substance, the power to modify itself in accordance with its potential or 'upādāna', regardless of the presence or absence of instrumental (nimitta) causes. The Jaina therefore maintains that when the material cause (upādāna-kärana) is present, instrumental causes (nimitta-kāranas) will automatically appear; in other words, whatever conditions are present will function as nimitta-kāraṇa at the appropriate time. ...

Thus it appears that statements such as 'bondage of the soul is caused by (dravya-) karma', or 'the formation of the dravya-karma is brought about by the kașāyas (passions) of the soul' are purely conventional (vyavahāra) ones (ib., p. 48f.).
}

In a personal communication of 12.11.2011, P. S. Jaini added: "Karma is insentient and has no control over nimitta-kärana: the latter is subject to the conditions of dravya, kṣetra, kāla and bhāva, in contrast to the conception of the theists who consider Him to be able to kartum, akartum, anyatha kartum, etc."

54 Douglas (1966/1970, pp. 12, 53, cf. 148f).

55 Pk. viigimuchā/vitigicchā, Sk. vicikitsā.

56 Strong (2004, p. 72, n. 1) cites an unpublished paper of Swearer reporting on "the Buddha's excrement and his snot, enshrined in different sanctuaries in Northern Thailand". In his own analysis, he shows that excretions and hair and nails were treated as ambiguous objects in the Buddhist tradition, sometimes classified as contact relics and sometimes as body relics. However, $\mathrm{KV}_{1,2}$ XVIII.4 states the contrary Theravāda view vis-à-vis Buddhist heretics. See footnote 73. See Granoff (2008, p. 65, etc.) on similar examples from Vedic and Hindu literature. 
Jaina ascetics (water, wind, hair, nails), as well as their poison-removing words and sight. ${ }^{57}$ To this category also belongs speech, whose sound waves are in P $260 \mathrm{~b}$ ff. said to be formed by material atoms ejected in form of a thunderbolt (vajjasamthiya). These atoms are "unconscious (acitta) and inanimate (ajīva), but yet are inherent in souls" (Schubring 1935/2000, § 61, p. 137). ${ }^{58}$ The utterances of the saint can be either poison-removing (vayana-ṇivvisa) or poisonous (āsit-visa) if indeed used as a curse. ${ }^{59}$ With the exception of the power of touch (amosa), the powers of healing are not associated with living ascetics ${ }^{60}$ but with their secretions and excretions and with the objects touched by them, that is, with physical matter which is technically dead, though as it were containing the "congealed labour" of the samana. ${ }^{61}$ Current religious practice also shows that the body parts and the paraphernalia used exclusively by Jaina ascetics are treated as embodiments of ascetic energy. These objects are categorised as not just any form of matter, but as matter of a particularly pure and hence powerful ${ }^{62}$ and desirable nature. It is believed that their innate energy can be transferred by mere touch.

\footnotetext{
${ }^{57}$ In the Śvetāmbara canon, Uvavāiya $\left(\mathrm{Uv}_{1}\right)$ 24, Panhā $\overline{1}_{1} 6.1 .6$ and ĀvN 68-70 list five powers (Pk. laddhi, Sk. labdhi) of healing: 1. khela (Sk. kapha), 2. jalla (Sk. mala), 3. vippusa (S. viprușa), drop of urine (and faeces), 4. āmosa (Sk. āmrŕa), 5. savva (S. sarva) (Panhā has No. 4 as No. 1). The Śvetāmbara Ācārya Hemacandra, in his twelfth century Yogaśāstra (YŚ) 1.8, mentions seven powers of healing: kapha, viprușa, jalla, mala, viștā, ämrśa and sarva (he additionally distinguishes jalla and mala and adds viștā).

The corresponding Digambara list does not use the term laddhi but the term iddhi (Sk. r. $d d h i$ ). The list of eight osahi-iddhis (Sk. aușadhi-ṛddhi) is given in Ācārya Yativrsabha's c. 5th century Tiloyapannattī $\left(\mathrm{TP}_{1}\right)$ II.4.1078-1087:
}

1. touch (Pk. āmosa, Sk. āmarśa/āmrísa),

2. phlegm (Pk. khela, Sk. kapha or "kșela" = śleșma),

3. secretions such as sweat and mucus (jalla),

4. waste matter (from the tongue, lip, teeth, nose and ear) (mala),

5. excreta (urine and excrement) (vișa),

6. everything (that was in contact with the ascetic body) (Pk. savva, Sk. sarva),

7. poison-removing words (Pk. vayana-ṇivvisa, Sk. vacana-nirvișa),

8. poison-removing sight (Pk. dițthi-ṇivvisa, Sk. dṛsți-nirvișa).

In this list, no further differentiation of vișa is offered. Instead two somewhat different items (no. 7-8) are added. For a discussion of a similar list in Virasena's ninth century commentary on the Șaṭkhaṇ̂̄āgama of Puṣpadanta and Bhūtabali, see Wiley (2012, pp. 156-8). Patañjali, in his Yogasūtra (YS) III, lists many superhuman powers acquired through yoga, but not the power of healing.

58 See P 260b ff. summarised by Schubring (1935/2000, p. $\S$ 61, 68f.). For a discussion of Schubring's implicit theory of the Jaina doctrine of influence qua karmic binding, see Flügel (2010a, p. 130f.).

${ }^{59}$ See $\mathrm{TP}_{1}$ II.4.1088-1098 for instance.

${ }^{60}$ In the same way as the auto-commentary on $\mathrm{TS}_{1} 10.7$, which also mentions the healing powers of the body secretions of the most advanced Jaina ascetics, Āryikā Viśuddhamatī emphasized in her commentary on $\mathrm{TP}_{1}$ II.4.1086, that this power results from tapas which is difficult to accomplish. It is associated in particular with tapasvin/īs, monks and nuns specialised in long fasts: jis r duṣkar tap se yukta muniyom dvārā sparśa kiyā huā jal evam vāyu tathā rom aur nack ādi vyādhi ke haranevāle hī jāte haim, vah sarvaușadhi nāmak ṛddhi hai.

${ }^{61}$ Jain (1947, p. 227) in his discussion of passages mentioning curing by touch, however, points to the role of spells and charms and the help of gods (rather than powerful matter) in the ascetics' exercise of magical powers.

62 The constitutive opposition of purity and power, posited by Dumont (1966/1980) for Hinduism, has been transcended by Jaina and Buddhist systems. 
The belief in the power (here: labdhi) of dissociated body particles of Jaina ascetics is unmistakable in the following passage of Hemacandra's twelfth century Jaina universal history, the Triṣaștíśalākapuruṣacaritra (TŚPC) translated by H. Johnson (1931-1962) as "The Lives of the 63 Illustrious Persons":

By the power of their yoga all the magic powers [labdhi], phlegm, etc., became apparent like mountain herbs by moonlight. The body of a leper, if rubbed with just a particle of their phlegm, became golden like a heap of copper from kotivedha juice. The impurities from their eyes, ears, etc., and from their limbs, having the fragrance of musk, were a medicine for all sick people. Merely from touching their bodies, sick people became well, as if from a bath of nectar. Water, both rain-water and running water of rivers, etc., that had been in contact with their bodies, removed all diseases, as the light of the sun destroys darkness. The bad effects of poison, etc., disappeared from wind that touches their bodies, just as other elephants disappear because of the scent of the ichor of a rutting elephant. Food, etc., infected with poison that was placed in their dishes or mouths, became free from poison like pieces of nectar. By hearing their speech, pain left any one afflicted with a very poisonous disease, as poison disappears by a syllable of a charm. The nails, hair, teeth, and every thing else produced by their bodies became medicines, just as water in pearl-oysters becomes pearls (TŚPC 1. 843-855, translated by Johnson 1931 I, pp. 75-77). ${ }^{63}$

The contemporary Sthānakavāsī monk Amar Muni pointed to divergent opinions between those who believe that the body parts of Jaina ascetics are themselves powerful, and others who assert that the will of the ascetic alone endows them with energy. ${ }^{64}$ The question is pertinent in the context of the assessment of the powers of healing (ausadhi-ṛddhi). In his explanation of the canonical text Uvavāiya $\left(\mathrm{Uv}_{2}\right)$ 24b-c, Amar Muni refers to a passage in Jinadāsagaṇi Mahattara's seventh century $\bar{A}$ vaśyakacūrni $(\overline{\mathrm{A} v C})^{65}$ which insists that the auṣadhi-ṛdhis "are effective only when the ascetic wishes and resolves to use them for the benefit of others" (p. 64). ${ }^{66}$ A different view is expressed, for instance, in Siddhasenasūri ${ }^{67}$ twelfth century

\footnotetext{
63 Similar potencies are evident in the Hindu traditions. On the "impersonal potency" of healing attributed to the touch of "royal sages" (rājarși), see Gonda (1956, p. 45); and Parry (1982, p. 96) on the "miraculous medicinal potencies" of the bodily emissions of Aghorī ascetics, for instance.

${ }^{64}$ In line with the second interpretation, $\mathrm{Uv}_{3} 24 \mathrm{~b}-\mathrm{c}$ defines the powers of Jaina ascetics not as iddhis but as laddhis, or attainments, that is, not as intrinsic qualities or properties of a living being, but as consequences of specific austerities, some of which are detailed in $\mathrm{Uv}_{3} 24 \mathrm{c}$. These powers can apparently be conveyed at will upon material atoms disregarding their locating inside or outside the body.

65 On dates and author, see Balbir (1993, p. 81).

66 The untraced text in "ĀvC I" is cited in Amar Muni's Hindī commentary, also referred to by Wiley (2012, p. 154): āmosahipattānam rogābhibhūtam attānam param vā javevi tigicchāmī| ti samcitteūṇa āsurati te takkhaṇā ceva vavagayarogātamkạ̣ karoti \|| (cited in $\mathrm{Uv}_{2}$, p. 64).

67 There are three Siddhasenas mentioned in this article: Siddhasenadivākara (c. 7th century), Siddhasenaganin (c. 9th Century) and Siddhasenasūri (12th century) who belonged to the succession of Abhayadevasūri of the Candragaccha/Rājagaccha. The last two are Śvetāmbara. The first is claimed to be Yāpanīya by Upadhye (1974/1983, p. 200) and Jaini (1978/2000, p. 59).
} 
Tattvabodhavikāśinī (TJV) 270-271, a commentary (vrtti) on Nemicandrasūri's eleventh century Pravacanasāroddhāra (PS) 270-271, which stresses the intrinsic healing powers of detached body parts of Jaina ascetics. ${ }^{68}$

In part six of the TŚPC, bone relics (asthi) of the Jinas are also described as having "power" (prabhāva) ( $\mathrm{TŚ}^{\mathrm{P}} \mathrm{C}_{1}$ 6.565) and conveying "good fortune" (kalyāna) (TŚPC ${ }_{1}$ 13.269). The conundrum, how this can be understood in the context of Jaina teachings will be addressed in the remainder of this text.

\section{The Question of the Power of Relics}

In which ways can material objects such as bone relics be conceptualised in Jaina philosophical terms as repositories of transmittable living energy of a deceased living being? The standard approach, both scholastic and academic, is to simply dismiss relic practices as delusional forms of 'popular religion' or 'magical thinking' that deviate from the true teaching of the Jina. Another approach is to accept 'folk theories' on the metaphysical presence of the powers of the deceased in the relics at face value without seeking an explanation. By contrast, the main argument of the present article, that in the Jaina doctrinal context bone relics are treated as sacred objects because of their specific material rather than metaphysical qualities, is based on the assumption that relics are conceptualised by participants in the same way as other dissociated body parts of Jaina ascetics, despite the fact that they are not included in the standard auṣadhi- or other r rddhi/labdhi lists. The ritual treatment of the dead body of an ascetic, or of parts thereof, as powerful sacred matter, described in the narrative portions of the canon ${ }^{69}$ and in recent ethnography ${ }^{70}$, is also predicated, one would assume, on the implicit presupposition that it is composed of particularly refined karmically produced particles which turn from animated into inanimated matter after being disconnected from the soul, and that the energy stored in these unique particles can somehow be transmitted by physical contiguity, even after death and cremation. Yet, this is rarely, if ever, explicitly

68 "As is stated in Avashyaka Churni 1 - A shraman endowed with Amarshaushadi labdhi can cure a person or himself by his touch only when he resolved - 'I wish to cure him.' As long as he does not resolve thus this power does not become effective as a cure. However, in many scriptures there are mentions of instances where the smell or touch of the excreta of such accomplished ascetics naturally cure many diseases. More details on this subject are available in the commentaries (Tika and Vyakhya) of Dvar 271 of Pravacanasaroddhar (Amar Muni in $\mathrm{Uv}_{3}$, p. 64, translated by S. Bothara)".

69 Jaini $(1985$, p. 89).

${ }^{70}$ Flügel $(2008,2010 b, 2011)$. 
discussed in the texts, certainly not in karman theoretical terms ${ }^{71}$, nor is relic worship a highly rationalised Jaina religious practice, for instance in terms of quasicontractual forms of merit transfer. The question, how disembodied ascetic power is (or could be) conceptualised in Jaina philosophy is thus, to some extent, an exercise in philosophical speculation, although it will in the following be investigated with reference to relevant Jaina philosophical debates and contemporary Jaina practices.

The question, how the power attributed to relics and other detached body parts of Jaina ascetics can be understood from the point of view of Jaina doctrine has never been raised in the academic literature. ${ }^{72}$ Significant is what Jaina scholasticism has to say about this issue. ${ }^{73} \mathrm{We}$ will find that late canonical Jaina scriptures such as the Viyāhapannatti and its commentaries, maybe only these texts, offer ways of understanding materially embodied ascetic power in Jaina doctrinal terms. By contrast, philosophical rationalisations of the process of transmission of ascetic energy via disembodied material objects are very rarely encountered, if at all. These are considered to be heretical, since the existence of ascetic energy is predicated on a connection of karmic matter with the soul. Apocryphal beliefs in the

\footnotetext{
71 In this respect only, the dominant strictly dualist Jaina position corresponds to the Theravāda Buddhist view. Cf. $\mathrm{KV}_{1,2}$ (XVI.8 for the controversy concerning the "heretical" views of the Sammitiya Buddhists that "material qualities are results [of karmas]" (rüpam [kamma-] vipāko) and $\mathrm{KV}_{1,2}$ (VII.7 for the view of the Andhaka Buddhists that "land is the result of action" pațavi kammavipāko), that for instance "the earth is a result of the action of a being who is a world-monarch" (pathavi cakkavattisattassa kammavipāko). Halbfass (1991/1992, p. 343, n. 125) also points to the last passage. On the difference between kamma and kammavipāko see also the Buddhist controversy described in KV VIII.9. In classical Jaina doctrine, one of the terms specifying the results (phala) of automatically maturing experienced karman is also vivāga (Sk. vipāka), not to be confused with karmic particles (karma-pudgala) attracted by the resulting action. The dualist position of classical Jainism, mediated by the concept of the karmic particle, contrasts with the later Theravāda position documented in the KV, "that the result of (vipāka) of kamma is a matter of subjective experience, that material effects per se do not arise directly because of human action" (McDermott 1975, p. 433).

72 Brown (1998, p. 33) asked a similar question with regard to Buddha images: "If the Buddha produced miracles through his power of iddhi, for example, is this also what allows an image to produce a miracle?" His answer, like the argument proposed in this article for the case of bone relics, points to the materiality of the sacred object. Granoff (1998a, p. 58), by contrast, pointed out that for the Jaina monk "in many cases an image, particularly a miracle-working image, is not an image but the Jina himself", although "the modern scholar knows of course that it is the image of the Jina the monk/author of these hymns is seeing".

73 According to the canonical Paṇnavanā (P) 1.84, excreta and body secretions are said to populated by uncountable sammucchima-manussa, tiny short-lived human beings invisible to the human eye, and should therefore not be touched at all. Buddhist texts report the existence of similar views amongst at least some Buddhist monks. Jaina mendicants are not allowed to study at a site where body parts such as excrement, bones, blood, etc. are close (Thaṇa 475b according to Schubring 1935/2000, § 150, p. 267, cf. Balbir 1990a). At the Spalding symposium, held in Oxford in honour of Professor Karel Werner's 85th birthday, Lance Cousins kindly pointed me to the late text Kathāvatthu, or Points of Controversy, of the Abhidhammapitaka for Buddhist debates on the excrement of the Buddha. Some Buddhist monks, according to the commentary (KVA) to KV $\mathrm{K}_{1,2}$ XVIII.4 some of the Andhakas and Uttarāpathakas, held the view that "the excreta [uccāra-passāvo] of the Exalted Buddha excelled all other odorous things". The refutation of this view points to the "fact" that secretions of the Buddha were not collected by anyone to make cosmetics, etc.
} 
transferability of karman from one living being to another can occasionally be encountered $^{74}$, but are a minority view in Jaina discourse. Everyone knows that karman accrues only to the living body of the agent, that is, the embodied soul, and travels with the soul of the deceased to the place of its next incarnation. This leaves only the physical attributes of the detached body parts of the ascetics as the potentially transmittable source of the power of relics.

How then, if at all, can the often reported quasi 'alchemical' ${ }^{75}$ processes of crystallisation of ascetic energy in bone relics and other body parts be cogitated in Jaina doctrinal terms? It seems, this is only possible if a concept of dead matter is posited that remains charged with the results of karmically generated energy, for some time, even after its dissociation from the embodied soul.

\section{Formation of the Body}

Jaina interpretations of the qualities of disembodied material particles presuppose the classical Jaina concept of embodied matter and theoretical analysis of the process of embodiment. ${ }^{76}$ The basic components of body formation are the processes of attraction, bondage, and ejection of inanimate material particles by the embodied soul (Viy 1 18.3.5 [743b]), that is, the interaction between soul and matter through the inflow and outflow of material particles. ${ }^{77}$ Two types of material particles are strictly distinguished in the texts: matter that constitutes the five bodies (sarīra) of the living being, that is, the embodied soul ${ }^{78}$, in accordance with its karmic $\operatorname{code}^{79}$, and matter that is drawn from exterior (bāhira-poggala) for short moments only without being incorporated. From the point of view of their status in the karmic cycle, the texts further differentiate three modes of material particles:

\footnotetext{
74 See Cort (2003, p. 133ff.), Laughlin (2003, pp. 41, 47f.). Cf. Halbfass (1991/1992, p. 321) on Nyāya conceptions of sharers of karman (karmabhāgin) or the obstruction of the ripening of karman through interference of karman of other living beings who are bound to have a shared experience (samānopabhoga).

75 See Balbir (1990b, 1992), White (1996), and Sikdar (1980). For recent discussions of the lists of the powers of the body of a yogin, though not body relics, which influenced the Jaina conceptions as well, see the articles in Jacobsen (2012).

76 For details of the classical Jaina theory of the formation of the body, see Wiley (2000, Ch, p. 3).

77 See Schubring $(1935 / 2000, \S 60$, p. 134) on the process of amalgamating (sāhanana), retaining (ähāra or āgarisa) (cf. P 6.683ff., in Mālvaniyā 1971, p. 303), and secreting (bheya) atoms in Viy ${ }_{1}$ 12.4.b-c $(567 \mathrm{a}-569 \mathrm{a})$.

78 Viy. 8.1 refers to living beings only, which have a minimum of three bodies: gross, fiery, and karman and a maximum of four at any specific moment of time.

For the various permutations of body types and classes of beings, see the summary table by Wiley (2000, p. 151). She points to the specifically Digambara distinction between separable (prthaka-vaikriyaśarìra) and non-separable (prthaka-v.-ś.) transformation bodies (ib., pp. 147-150).

79 First matter constituting the karmic body is attracted by the karmic body itself, and then suitable matter for constituting the other bodies which are pruced by different forms of näma-karman.
} 
(1) "attractable particles" (gahana-poggala/davva) ${ }^{80}$, (2) "attracted particles" (āhārap.), that is, particles by means of which the organic body of a living being is gradually built up, and (3) "ejected particles" (nijjarā-p.), which were discarded by acts of self-purification or final liberation of the soul. Attractable and unattractable forms of insentient matter are further sub-divided in accordance with the theoretical quantity of their elementary atoms (paramānu-p.) forming aggregates (skandha) of classes (vaggan $\bar{a}$ ) of equal numerical value. The qualities of such aggregates are also distinguished by their basic physical attributes such as shape, colour, smell, etc. ${ }^{81}$

The locus classicus for the Jaina doctrine of the five bodies is $\mathrm{P}_{2} 12.5^{82}$ The manifest body of a living being is a composite of a minimum of two ${ }^{83}$ and a maximum of four different types of bodies (sarīra) since the vaikriya and āhäraka bodies cannot co-exist. These are graded in terms of the increasing fineness and density of their elementary material atoms (poggala) and molecules (khamdha):

(1) gross body (urāliya-s./orāliya-s., Sk. audārika-ś.),

(2) transformation body (veuvviya-s., Sk. vaikriya-ś.),

(3) translocation body (āhāraga-s., Sk. āhāraka-ś.),

(4) fiery body (teyaga-s., Sk. taijasa-ś.), and

(5) karman body (kammaga-s., Sk. kārmaṇa-ś.).

${ }^{80} \mathrm{Cf}$. the interpretations of $\mathrm{TS}_{1} 8.2$ (sakașāyatvāj jīvah karmano yogyān pudgalān ādatte) by the translator N. Tatia: "Because of its passions, the soul attracts and assimilates the material particles of karmic bondage"; which should better be translated: "... material particles capable of turning into karmic bondage". Cf. TS $_{1}$ 8.24-25. Schubring $(1935 / 2000, \S 84$, p. 173) emphasized that "matter attracted by soul is not yet Karman, but it comes to be so"). It is not exactly stated in TS 18.2 that "Karmic matter is said to be found 'floating free' in every part of occupied space" (Jaini 1979, p. 112). What is meant is that fine matter capable of being transformed into karmic matter (karmano yogyān-pudgalān) is everywhere (personal communication Jaini, March 2008). See $\mathrm{TS}_{1-2} 8.3$ \& 8.25, SAS 8.2, and Sikdar (1987, pp. 42, 80f.). Cf. Wiley (2000, pp. 408-410 on types of "graspable" matter. The texts distinguish between attractable/non-attractable matter in terms of degrees of subtlety. Matter capable of being transformed into a karmic body is so refined that it is invisible to the eye.

81 Sikdar (1987, p. 223-253). Frauwallner (1953/1997 II: 188) finds it "remarkable" that in the Jaina theory of matter the qualities of the elements "occur to all the atoms equally", while the distinct qualities of aggregates are caused by parināma.-See also Schubring (1935/2000, § 60, p. 134), who points to the vocabulary of the self-referential processes of attracting (sāhanana)—elsewhere called āgarisa-and secreting (bheya) material atoms in $\mathrm{Viy}_{1}$ 12.4.b-c (567a-569a), where seven kinds of atomic regroupment (poggala-pariyatta) are distinguished in the context of the theoretical analysis of the mechanisms responsible for building up and transforming the body by changing (parināma) and extracting (nijjarā) karmic particles.

82 pamca sarīrayā paṇnattā, tam jahā - orālie veuvvie āhārae teyae kammae $\left(\mathrm{P}_{2} 12.5\right)$. See in Sanskrit $\mathrm{TS}_{1-2} 2.37-49$.

83 Karman and fiery body, the "bearer of potential energies" (Schubring 1935/2000, § 62, p. 139): "All bodies except the earthly one are closely linked with the soul" (ib.). 
The maximal five bodies of a living being ${ }^{84}$ are generated by the kārmana-śarīra which is itself composed of invisible subtle particles that attract gross material particles from the exterior and form them into atomic compounds of different quality. According to classical Jaina karman theory, the presence or absence of the capacity (labdhi) for the complete development of the personal body, the paryāptanäma-karman (Pk. pajjatta-nāma-kamma) ${ }^{85}$, which is a subtle form of karmic matter attached to the unliberated soul from the very beginning, determines the ability to attract from outside and further transform inanimate matter into animate matter and to build up and maintain the maximal five types of bodies that are attached to and obstructing the soul. ${ }^{86}$ It is the quality and quantity of this and other näma-karman which constitutes individual living beings of differential structure and ability. ${ }^{87}$ The soul with the help of its paryāpta-näma-karman has the power to attract suitable types of matter from outside the body which were already transformed naturally. The material particles are then further modified within the body by karmic processes. ${ }^{88}$ First, elementary forms of body matter are created which are differentiated into a liquid part (rasa-bhāga) and a solid part (khala-bhāga). From the two basic varieties seven primary forms of organic matter (dhātu) are produced, of which flesh (mämsa) and bones (asthi or sthira) are the most significant solid varieties. The physical strength of the body is dependent on the quality of the joints connecting the bones, which are determined by the solid joint making karman (samhanana-näma-karman), which is considered as a type of physical power (śakti) producing karman. ${ }^{89}$ Even the physical attractiveness or repulsiveness, produced by śubha- and aśubha-nāma-karman, is a product of body forming karman.

Karman (here: action, that is, karman that comes to fruition) attracts matter in a selective way: good karman (punya-karman) attracts more subtle matter than bad karman (pāpa-karman). By means of ascetic practices, including non-action (ayoga), the influx of matter from the outside can be stopped (samvara), gross forms of matter can be transformed (parināma) into subtle forms of matter, and matter can be discharged entirely from the body (nirjara $\bar{a}$ ). The processes of selective attraction and of karmic transformation and dissociation of matter from the body of the ascetic thus lead to the autocatalytic production of compounds of matter of very subtle and pure quality, and finally to the liberation of the soul from embodiment. When they are removed from the body, dissociated material particles return to their original

\footnotetext{
${ }^{84} \mathrm{Viy}_{1}$ 13.7.1c (622b) distinguishes further two further bodies for beings who have not yet been fully embodied in them: transitional transformation body (veuvviya-mīsaya-kāya) and transitional transposition body (āhāraya-mīsaya-kāya). See Deleu (1970, p. 200), and Schubring (1935/2000, § 62, pp. 137-139) who suggested that instead of "āhāraka 'attracting' its name should be ädhäraka in that the body represents a 'vessel'". On the Jain theory of five bodies see Frauwallner (1953/1997 I: 142). Notably, the heavenly or vaimānika gods do not possess a gross body according to classical Jainism. On contrasting Sāṃkhya views compare for instance Oberlies (2006).

${ }^{85}$ Its opposite is called apajjatta-nāma-kamma (Sk. aparyāpta-nāma-karman).

${ }^{86}$ For details on näma-karman, see $\operatorname{TS}_{1-2} 8.12$, SAS 8.11, Glasenapp (1915/1942, pp. 11-18) and Wiley (2000, pp. 117-231).

${ }^{87}$ The body of a Tîrthankara is made of the purest gross-body (parama-audārika) atoms.

${ }^{88}$ For details, see Wiley (2000).

${ }^{89}$ See Glasenapp (1915/1942, p. 14f.), Wiley (2000, pp. 164, 170, 173f., 186, 220).
} 
inanimate state and can then be attracted by another embodied soul. The same applies to aggregates (skandha) of material atoms that had been attracted, transformed by their association with the soul, and finally dissociated (Viy $\left.{ }_{1} 14.4\right) .{ }^{90}$ The question is whether matter that was transformed and refined through karmic processes retains its unique qualities and can be selectively reappropriated again by another living being.

\section{Embodied Pure and Auspicious Matter}

Matter (pudgala) that is auspicious (śubha) and pure (śuddha) is occasionally referred to in late canonical and post-canonical texts to explain special ascetic powers $^{91}$ believed to be crystallised in the aggregates of particularly refined matter that constitute the living ascetic body. Most prominent is the following passage in the Śvetāmbara version of Umāsvāti's fourth century Sanskrit Tattvārthasūtra (TS $\left.{ }_{1}\right)$ 2.49, the principal text of classical Jaina doctrine accepted by both Digambaras and Śvetāmbaras, which explains the features of the conveyance body (āhāraka-śarīra), known to be effective only for very short time ${ }^{92}$, that allows the ascetic to travel to distant places for a short period of time while remaining connected with his physical body (audāika-śarīra). The conveyance body is made of a subtle form of matter that is very auspicious and pure (śubha-viśuddha) and invisible to the eye: ${ }^{93}$

The conveyance body is made of auspicious, pure, non-obstructive and nonobstructed matter. It can be created only by a learned ascetic conversant with the fourteen books of the early literature $\left(\mathrm{TS}_{1} 2.49\right.$, translated by $\mathrm{N}$. Tatia).

The Digambara version of the TS that was preserved in the fifth century commentary of Ācārya Pūjyapāda, the Sarvārthasiddhi (SaSi), gives a different ending to the same verse: ${ }^{94}$

The conveyance body is made of auspicious, pure, non-obstructive and nonobstructed matter. Only an ascetic who is self-restrained but prone to laxity uses this body $\left(\mathrm{TS}_{2} 2.49\right.$, in $\mathrm{SaSi}_{3}$, translated by Jain).

In his commentary, Pūjyapāda focuses not on the creation but on the use of these extraordinary bodies and stresses that it is slightly incorrect to strive for the

\footnotetext{
90 See infra.

91 For two types of matter used in the magical constitution of temporary bodies, see Schubring (1935/ 2000, § 181, p. 318).

92 The "heretical" view of the Buddhist Mahimsāsakas and Sammitiyas reported in the commentary KVA to $\mathrm{KV}_{1,2}$ VIII.9 and XVI.7, that because "action of body and speech [are] either good or bad" the "material qualities (engaged therein) are also either good or bad"] (rūpam kusalam pi akusalam pīti) [is slightly different. What is meant is not a material karmic result (unthinkable for a Buddhist), but "the physical motions engaged therein" (gesticulation, etc.) (KVA XVI.7).]

93 śubham viśuddham avyāghāti cāhārakam caturdaśa-pūrvadhara-eva $\left(\mathrm{TS}_{1-2} 2.49\right)$.

94 śubham viśuddham avyāghāti cāhārakam pramatta-samyatasya-eva (TS 2.49, in $\mathrm{SaSi}_{3}$ ).
} 
accomplishment of a pure and hence powerful body such as this and that one should make use of it if one is not self-restrained. However, the existence of "auspicious" and "pure" matter which creates "merit" (punya-karma) is not disputed by Pūjyapāda, as his commentary shows: ${ }^{95}$

The expression 'auspicious matter' in the sutra means that the clusters of matter that constitute the conveyance body are pleasant in colour, odour, touch and taste and that they produce merit. 'Pure matter' implies that the clusters are transparent, shiny and conducive to harmless conduct. 'Unobstructive and unobstructed matter' [avyāghāti] signifies that these clusters have free unimpeded movement to the destination $\left(\mathrm{SaSi}_{3} 2.49\right.$, summary by Tatia 1994 , p. 60). ${ }^{96}$

Since the terms śubha and viśuddha can equally refer to "wholesome" and to "shining" forms of matter, the passage is somewhat ambiguous. Important for the discussion of sacred matter is that in this context it has been understood to be a merit-producing subtle form of matter. However, it is not explained how this subtle form of matter produces merit. ${ }^{97}$ This form of matter exists only in connection with the body of a living being.

\section{Disembodied Pure and Auspicious Matter}

Concepts of disembodied 'pure-' and 'auspicious matter', contrasted with 'impure-' or 'inauspicious matter', appear, in different contexts, already in the Prakrit Śvetāmbara Āgamas, especially in the Viyāhapannatti, most prominently in Viy. 5.9 and 14.9; the first being an early passage and the second a late passage representing the most advanced theory of matter in the canon. These passages reflect different stages of the new Jaina conception of matter which co-evolved together with the transition from voluntaristic to systemic conceptions of karman in the middle and late canonical periods. The model of karman as a system works with a concept of action without an agent. It represents action as an objective auto-poietic process, analogous to the agricultural seed-plant cycle, with karmic matter functioning as a

\footnotetext{
95 śubhakāraṇatvācchubhavyapadeśah I śubhakarmaṇa āhārakakāyayogasya kāranatvācchubhamityucyate annasya prānavyapadeśavat | viśuddhakāryatvādviśsddhavyapadeśah | viśuddhasya punyakarmanah aśabalasya niravadyasya kāryatvādviśuddhamityucyate tantūnām kāryāsavyapadeśavat | ... I ( $\left.\mathrm{SaSi}_{1} 357\right)$.
}

96 Jain (1960/1992, p. 81), in his even less literal translation, renders the meaning as follows: "Sometimes the cause is identified with the effect. ... Since it (the projectable body) brings about spotless and pure result, it is called pure". The text explains, however, that a monk who uses these powers comes down to the sixth of the fourteen qualitative stages (gunasthāna) of the path of salvation. On $\mathrm{TS}_{1-2} 2.9$, see also Jacobi (1906, p. 308).

97 See also Wiley (2000, p. 144) on TS 2.49; and Wiley (2012, p. 185f.) 
seed-like particle. ${ }^{98}$ In Jaina philosophy of nature, matter, like the soul, is also conceived as an 'active' or 'moving' (kriya) substance, unlike the other three of altogether five substances (pañcāstikāya). It undergoes somewhat similar systemic processes of self-transformation (parināma), of aggregation and disaggregation, as does the karman of the embodied soul that automatically come to fruition. Classical Jaina cosmology describes the parallel mechanisms of self-transformation of the embodied soul and of inanimate matter and the results of their interaction. ${ }^{99}$

A few examples illustrate the range of application of the Prakrit terms suddha and subha as attributes of disembodied matter: Viy 14.2 (634a-636a), a text which Ohira (1994, p. 64) locates in the fourth-fifth canonical stage (4th-5th century C.E.), analyses spirit possession (ummāya) as an effect of the penetration of one living body by "inauspicious particles" (asubha-poggala) sent off by another; in this case a demon or god. This passage can be interpreted in two ways: Either it suggests that the transmitted particles have moral characteristics, though there is no explict reference to a 'transfer of demerit' ( $p \bar{a} p \bar{a})$, or, more likely, that the transmitted matter itself has qualities which induces negative or "unpleasant" states. From the point of view of karman doctrine, of course, possession, though experienced as real, is a form of delusion, which can be cured by the application of discriminative knowledge resulting in the ejection of the troublesome particles. ${ }^{100}$

A similar example is the brightness of the day, believed to be caused by the rays of light sent out by the sun (which is conceived as a living god in classical Jaina cosmology). In Viy 1 5.9.2 (246b) and 14.9.4 (656a), two passages which Ohira (1994, p. 64) located both in the "third canonical stage" (1st century B.C.E.-3rd century C.E.), light is explained in terms of the concept of 'pure' or 'shining' matter (the same principle is applied to darkness of the night which is interpreted to be the effect of dark matter, tamas-kāya). Here, the transmitted energy is not inducing moral states in a living being, but is simply described as a natural phenomenon. ${ }^{101}$ According to Ohira (1994, p. 97), the ancient view "that light, darkness and sound are independent entities", is invoked here, "which seems to have been prevalent in the olden days when these were not yet considered as properties of substance".

\footnotetext{
98 Bhatt (1983, p. 111) located the first appearance of the theory of matter in the second layer and the advanced theory in the last of three "textual layers" of the Viy. The fully developed "system theory" of karman developed from c. the first to fifth centuries C.E. It culminated in the Śvetāmbara tradition on the focus on the distinction between jīva and ajīva and "the usage of ajīva in the sense of the astikayas minus jīva and addhāsamaya" (Ohira 1994, p. 113). Cf. Werner (1996, p. 76) on Vedic concepts of "individual organisms" as "self-regulatory systems", as "structural-functional units".

99 See infra on the theory of transformation.

${ }^{100}$ Cf. Kapferer (1997) for similar methods employed in Sinhalese Buddhist anti-sorcery rites.

101 The words subha- and asubha-poggala mentioned in Viy ${ }_{1}$ 5.9.2 (246b), 14.8, etc., are ambiguous, and can alternatively be translated as in/auspicious or not/shining, but in this context were rendered by Schubring (1935/2000, § 69, p. 151) and Deleu (1970, p. 204) as "pure" and "impure". See Sikdar (1987, p. 235 and Tatia 1994, p. 60) who prefer "inauspicious/auspicious".
} 


\section{Temporary Bodies Created by Ascetics}

The clearest and maybe only unequivocal exposition of the material qualities and powers of ejected particles, their purity or impurity, and of their effects offered by the Jaina scriptures is the analysis of the concepts of teya-less $\bar{a}$ (Sk. tejo-leśy $\bar{a}$ ) and kamma-les(s)ā (Sk. karma-leśy $\bar{a}$ ) in the Viy. ${ }^{102}$ Both terms refer to forms of radiating energy generated by the fiery body of advanced Jaina ascetics. According to P 17.1188-1198, the kamma-lessa, or karmically produced radiance or personal aura of the ascetic, ${ }^{103}$ is intrinsically connected with the quality and quantity of his (her) iddhis. ${ }^{104}$ In Viy 14.9 .1 (655a) it is compared with material objects such as the radiance of the sun and moon gods. The commentator Abhayadeva (ViyVr 14.9.1) noted that the term sakarma-leśy $\bar{a}$ could be interpreted by imperfect monks (chadmastha) in the sense that leśya atself is karman. ${ }^{105}$ But this is not the case, despite the ambiguous compound. ${ }^{106}$ Both Schubring (1935/2000, § 89, p. 185), Deleu (1970, p. 212) ${ }^{107}$ and Ohira (1994, p. 126) emphasize that the "colouration of the soul", (bhāva-) leśyā, "is not karma", but is only carried by the kārmana-śarīra during transmigration. Ohira (ib., p. 127f.) argues that in the theory of the process of transmigration it performs the function of "pinpointing more exactly" a precise place for the rebirth of a soul within a cosmographic region, matching the final leśy $\bar{a}$ of its last incarnation before death. However, in time, this "original function" of the term was forgotten and "leśyā as the personality-index of beings came to the fore"

\footnotetext{
102 See the proposed chronology of Tsuchihashi (1983, p. 202).

${ }^{103}$ Schubring (1935, p. 267) suggested that this conception stems from the "popular belief in bright good and dark bad hearts". Mālvaniyā (1971, p. 356) translated leśya as "mental temperament" and characterised it as "nothing but a sort of transformation or modification of matter, which takes place depending on the soul" (ib., p. 353). Building on this, Ohira (1994, p. 129) uses the description "psychical and emotional tinges". Flügel $(2008$, p. 7) suggested comparison with Heidegger's analysis of "mood". Malde (2010, p. 16), who discusses the salient literature, pleads for an "allegorical" understanding of many passages on leśya

104 Mālvaniyāa (1971, p. 353f.). See also Tsuchihashi (1983, p. 195f.).

105 Deleu's formulation could lead to the same conclusion. See also Tsuchihashi (1983, pp. 195-202).

106 See also ViyBh 14.9.123-125 on the difference between the two types of meaning of karma-leśy $\bar{a}$ : "pahlā artha karma ke yogya leśyā tathā dūsrā artha karma kī leśyā kiyā hai".

107 The "concrete particles endowed with a karmic lessā (sarūvim sakamma-lessā poggalā)" (Viy 14.9 [655a], tr. Deleu 1970, p. 212) that are radiating out from a living being in the form of brightness or heat are not the karma-leśya itself:
}

haṃtā goyamā! anagāre bhāviyaṇā appaṇo kammalessam na jānai, na pāsai, tạ̣ puṇa jīvam sarūvim sakammalessam jānai-pāsai" (Viy 4 14.9.123)

According to Abhayadeva's commentary (ViyVr 14.1) to Viy 14.1 (630a), summarised by Deleu (1970, p. 203), kamma-lessā refers to "Karmic lessā', i.e. lessā as a condition (bhāva-leśyā), not material lessā (dravya-leśyā) because the latter is well defined (avasthita)". Mālvaniyā (1971, p. 354) suggested that this distinction is rather late, since it cannot be found in the Pannvanā. See also Ohira (1994, p. 128). The same type of explanation is given by Abhayadeva (ViyVṛ 14.9.136) on teya-lessā in Viy ${ }_{1} 14.9 .5$ (656b) (Deleu 1970, p. 212). Schubring 1935 / 2000 § 99: 199, however, noted that the commentaries are often uncertain and sometimes clearly wrong. 
(ib., p. 129), now expressing "the total content making up an individual personality", that is, the "psychical and emotional tinges" (ib.) of the soul. ${ }^{108}$

The ontological status of the tejo-leśya is disputed in Jaina literature. According to the auto-commentary on $\mathrm{TS}_{1} 2.43$, summarised by Tatia $(1994, \mathrm{p} .57)$, the fiery power is "only an attribute" of the fiery body, produced by the temporary expansion of the space points of this body, and not a secondary body or entirely separate entity which can be emitted (nisrsța) ${ }^{109}$ or hurled intentionally from the body of the ascetic, although this is precisely the impression conveyed by the depiction of Gosāla's attack on Mahāvīra in Viy ${ }_{1}$ 15.C.7 (678a-b) (using the potentially deadly 'hot' form of his teya-lessā only to be repelled by Mahāvīra's 'cool' or protective teya-lessāa). ${ }^{110} \mathrm{Viy}_{1} 7.10 . \mathrm{b}$ (326b) similarly states that a monk who sends out a teyalessā composed of non-sentient (acitta) particles will produce light and heat where the teya-lessā falls down. ${ }^{111}$ Tsuchihashi (1983, p. 200) finds this "remarkable" and suspects that here a sentient being, a man, "manifests himself by virtue of his own inborn leśy $\bar{a}$ " in an inanimate entity.

According to the dominant Jaina interpretations, transformation, translocation and fiery bodies that are temporarily created by ascetics are never entirely separate from the soul, but karmically produced by a process of momentary expansion of the space points or paesas (Sk. pradeśa) ${ }^{112}$ occupied by the soul beyond the limits of the gross physical body. ${ }^{113}$ This process is called samugghāya (Sk. samudghāta), ${ }^{114}$ of which seven forms are distinguished in P 36 . However, in his commentary, the

108 Ohira (1994, p. 127) argued:

The concept of leśya, which expresses a general index of the total content making up an individual personality, was readily available in the then non-Jaina schools. ... It this appears that the Jaina theoreticians seized this current concept, and assigned to it a faculty to determine a being's next birth place. ... This leśy $\bar{a}$ must have been conceived as something material in connection with colour, like shining light tinged with colour.

109 Pk. nisattha.

110 Schubring (1954, p. 258) remarked: “[T]eya-lessā ist streng genommen unzutreffend mit teya gleichbedeutend gebraucht. Da es kein kalt-heisses tejas gibt (schon das kalte ist widersinnig), ist statt sîôsina ... sāôsina zu lesen". He agrees with Abhayadeva's commentary, on which see also Wiley (2000, p. 146).

111 See also Viy 18.10 (757a).

112 On the Jaina theory of the 'space points' or 'units of mass', see $\mathrm{TS}_{1-2} 5.7-5.11,5.14$, and Schubring (1935/2000, § 55ff. $126 \mathrm{ff}$., etc). According to the Jaina theory, material and immaterial objects are constituted temporarily by variable combinations of different elementary substances: the units (pradeśa) of space ( $\bar{a} k \bar{a} s a)$ occupied by particles of matter (pudgala), the medium of motion (dharma), the medium of rest (adharma), and of the soul (the concept of a unit of time or kāla is disputed within the tradition). Inevitably, liberated souls, or siddhas, are also imagined as quasi-material entities, endowed with a set of space-points (jīva-ghana), which are by definition immaterial, defining a particular occupied space (avagāhan $\bar{a}$ ) of a definite size in the realm of the liberated souls, or siddha-loka, which is predicated on the size of the body of the last rebirth. See Uv $169-177$, etc.; and W. Johnson's (1995, pp. 130, 143, 262f., 304) reflections on the putative 'original' concept of the materiality of the soul in early Jainism.

113 Wiley (2000, pp. 142-152) pointed out that "[i]n such an expansion called samudghāta, some of the space-points of the soul (ätma-pradeśa) remain in the principal body while others occupy the secondary body, which goes to another location in the universe while the principal body remains behind. ... leaving no physical residue because the matter forming these bodies is very subtle and they lack the impurities such as blood, bones, and flesh found in the audārika śarīra of humans and animals" (142f.). For the seven forms of samudghāta, see Viy 12.2 (129a) and P 36.

114 From the verb samohanai (S. samava-hana). 
Prajñāpanātịkā (PaṇnṬ), Ācārya Malayagiri, the twelfth century commentator, equated samudghāta with the process of ejection of karmic particles (nirjarā) by means of deliberate premature fruition (udīraña) of karman. While the space points of the temporary bodies retract to the space points of the physical body, the particles of dead karmic matter shed during samudghāta, remain outside the body. ${ }^{115}$ In Viy $_{1}$ 2.2 (129a) and P 36.561b-608a and 590a, amongst the seven types of samudghäta, taijasa-samudghāta, that is, hurling the taijasa-śarira-nāma-karman out of the body, is listed. But it is not included amongst the conscious acts of the soul (prayoga) in P 16, as Mālvaniyā (1971, p. 346) highlighted in contrast to Malayagiri. Hence, according to $\mathrm{P}$, using a taijasa-śarìra as a weapon seems to be ruled out.

Three examples of samudghāta are of interest here: (a) taijasa-samudghāta, (b) vaikriya-samudghāta, (c) āhāraka-samudghāta.

(a) The most significant case, elaborated only in Viy $_{1,2}$ 14.9.1 (655a), are the coloured karmic particles (sakamma-lessa-poggala), which emanante from the advanced Jaina ascetic which are compared and contrasted with the bright rays of the sun or the moon. ${ }^{116}$ In contrast to the im/pure and in/auspicious particles or the rays of the sun, the bright quality of the sakarma-leśya is characterised as a form of matter which "shines forth" and for a while retains its distinct karman-generated qualities even outside the emitting body.

The differences between karma-leśy $\bar{a}$ and tejo-leśya are not entirely clear. Two different reconstructions of the conceptual evolution have been offered by Tsuchihashi and Ohira.

Tsuchihashi (1983, p. 201f.) proposes four developmental stages of the term leśy $\bar{a}$ in the canon, designating: (1) radiance in general, especially of the deified heavenly bodies (leśyā), (2) lustre of an "organic" material substance (tejo-leśy $\bar{a}$ ), (3) coloration of the human body (Ājīvika), (4) colouration of karmic atoms (Jaina) (karma-leśyā). He points to the "remarkable" feature that the tejo-leśy $\bar{a}$ of an animate being penetrates an inanimate entity which is made to shine by "a substance-like lustre", and derives the term teya-lessā in Viy ${ }_{1} 7.10 .2 \mathrm{~b}$ (326b) and Viy $_{1} 15$ and the "later" "strictly jinistic" (ib., pp. 197, 200) term kamma-lessā in Viy $_{1} 14.9 .1$ (655a) with Schubring (1935/2000, § 97, pp. 195, "we have reason to believe that an adjective leśya was changed into a substantive") from the word leśa, particle, which he also interprets as a sanskritised form of Prakrit lesa (Tsuchihashi 1983 , p. 201f.). A. Mette (2010, p. 309) followed this interpretation and added a tentative analysis of the different historical layers of the oldest Jaina text on leśya in $\mathrm{Utt}_{1} 34$.

\footnotetext{
115 According to Mālvaniyā's (1971, p. 420) summary of Malayagiri’s commentary to this text (PannT), "samudghāta is nothing but expulsion (nirjarā) of very many particles of the karmas of one particular type, causing their early rise through the special process of udīrañ $\bar{a}$; this necessarily involves the previous refrainment from the experience of the fruits of the karmas of all other types".

116 Tsuchihashi (1983, p. 199) pointed to M. Hara's argument on the relatedness of the terms tapas, heatenergy, and tejas, glow-energy. Schubring (1954, p. 257) suggested, however, that the word teya does not designate here a "[concrete fire, but a collected, condensed transmitted energy or magical force] konkretes Feuer, sondern eine gesammelte, geballte ausgesendete Energie oder Kraft”. See note 119.
} 
Ohira (1978-1980, 1994, p. 126), by contrast, argues that the concept of karmaleśya stands for the earlier concept bhäva-leśya (antonym: dravya-leśya $)$, or psychic colour, and is itself older than the concept of the "non-sentient" tejo-leśy $\bar{a}$, which, according to her, is conceived as "the capacity of a personality index" of an ascetic. ${ }^{117}$ In contrast to karma-leśy $\bar{a}$, tejo-leśy $\bar{a}$ is conceived as a tangible 'fiery' ray of energy wilfully produced by an ascetic. It is produced by the ${ }^{118}$ fiery body (taijasa-śarîra) ${ }^{119}$ which itself is generated by extensive austerities (tapas). This ray of power can be either hot (usina) or cool (sìya) (Viy ${ }_{3} 15.65=\mathrm{Viy}_{1} 15 . \mathrm{B} .4$ [666a]). Because it is associated with "the miraculous powers of ascetics", Ohira (194, p. 97f.) assumes, it must be later than the theory that "light, darkness and sound are independent entities" rather than "properties of substance". ${ }^{20}$ She, therefore, places the two passages Viy ${ }_{1} 14.9 .1$ (655a) and Viy ${ }_{1}$ 7.10.b (326b) respectively between the first century B.C.E. and the third century C.E. and in the late fourth and the fifth century. ${ }^{121}$

(b-c) External matter can be temporarily used by an ascetic to conjure up illusory objects for instrumental purposes. Magical objects such as this are produced through the momentary attraction (āhāra) and transformation (vikriya) of 'improper' or 'impure' matter from outside of the body. Tejo-leśy ās, by contrast, are produced by the extraction of matter from inside. According to Viy ${ }_{1} 3.4 \mathrm{ff}$. (186a ff.), for creating a magical effect, not a material body or a fiery body but a transformation body (vaikriya-śarīra) has to be produced by a monk or a god. The powers associated with these detached objects seem phantastic and are generally described as

117 On Viy. 14.9: "Leśyā was thus understood in terms of karma-leśyā in the beginning" (Ohira 1994, p. 129). In Viy. 12.5 karma-leśya is immediately opposed to dravya-leśyā, the antonym of bhāva-leśā, which illustrates the substitution of bhāva-leśya by karma-leśya (ib.).

118 In Viy $_{3} 15.76=$ Viy $_{1}$ 15.B.4 (665b), as pointed out by Schubring (1935/2000, § 181, p. 317), the word samkhitta (Sk. sampsipta) describes the compression or accumulation of ascetic energy. See Tsuchihashi (1983, pp. 199-201) on the historical development of the term resulting in the meaning of "leśy $\bar{a}$ as something like cement bringing about "union of a being with (infusing) karmic substance"" (p. 201); a process which can be connected with notions of moral fluids in early Jainism, which Schubring $(1935 / 2000, \S 10,15)$ linked to "primitive sorcery".

119 On the concept of tejas, in textual Jainism, see Schubring (1935/2000, § 181, pp. 316-319), See also YŚ 1.9, and the commentary of Qvarnström. On the development of the term tejas (from the root tij, sharpen) from the Vedas to the Purānas, see Magnone (1993, 2009a, 2009b). For textual Buddhism, see Tambiah (1984, p. 203f.), citing Griswold. On tejas as "raw power" whose "manifold potential is open" in Sinhalese Buddhist sorcery rituals, see Kapferer (1997, p. 261).

${ }^{120}$ Ohira (1994, p. 98) assumes in the context of her discussion of leśya that "talk about the miraculous powers of ascetics" was not part of the older forms of Jainism. However, later in her text, she notes that there is already evidence in the Śvetāmbara scriptures of the existence of two early Jaina treatises on "magical power", the Cāraṇābhāvaṇā and the Paṇhavāyaraṇa (Praśnavyākaraṇa), which are now believed to be extinct; though Acharya (2007) seems to have the discovered a manuscript of the latter. Although Vavahāra 10, the text mentioning the Cāranābhāvan̄ā, is placed in the period between the third and first centuries B.C.E., Ohira (1994, p. 162) only concedes that the topic of magical power "might have arisen in a slightly earlier age, e.g. the fourth canonical stage", that is, in the fourth century C.E. See also Ohira (1994, pp. 56, 65).

121 "XIV.9.533 informs that sakarma-leśya-pudgala discharged from the abodes of the sun and moon gods shine forth. VII.10.307 explains that non-sentient tejo leśyā emitted by an angry ascetic shines and burns where it falls. The former belongs to the earlier stratum of the leśya theory in the third stage. The latter idea became popular when the Jainas began to talk about the miraculous power of ascetics. We place this text in the fifth canonical stage (Ohira 1994, p. 97f.)". 
'miraculous' (camatkārika) or 'magical' (māyika) in Jaina texts. These effects are just a magical illusion, as Schubring (1935/2000 § 181, p. 318) pointed out:

Viy. 154a; 190a in referring to both the monk and the god insists on saying that it means simply an effect on the senses and nothing real whatever.... For performing such an effect material particles not proper to the performer have to be attracted, and only by applying them, bāhirae poggale pariyāittā, he will succeed in producing it (Viy. 189a ff.; 283a, 643a; 705b; Jīv. 374b; Ṭhāṇ. $104 \mathrm{~b}$ ) in which case the texts differentiate such poggala that adhere to the performer from such adhering to the speaker or else to some third place (tattha-gaya, iha-g., annattha-g.).

Though lucid in theory, the dividing line between illusory ('magical') and real effects is often hard to discern in the texts describing the extraordinary abilities of Jaina ascetics. ${ }^{122}$ The vaikriya and taijasa powers can be used to produce both illusory and real objects outside the body and either for selfish and potentially harmful or salvific aims. ${ }^{123}$ Only the power to create and use the equally ephemeral $\bar{a}$ āraka or transformation body is said to be solely beneficial. ${ }^{124}$

\section{Substance and Mode}

The power of body relics cannot be explained in the same way as the power of karma-leśyās or of objects generated by magical tricks. What kind of material substance then constitutes body relics? Everything that exists is constituted by the five eternal substances (davva) known as the "mass of all that is" 125 (atthikāya) (Viy. 2.10). The five substances are: medium of motion (dhamma), medium of rest (adhamma), space (āgāsa), souls (jīva), and matter (poggala). They are all divisable and constituted by elementary units (paesa) which are conceived of as the invisible

122 Glasenapp (1925, p. 404, 1999, p. 446) argued that among the Jainas a dividing line between (Tirthankara) cult and magic is more difficult to draw than elsewhere because they also venerate Hindu gods and goddesses.

123 The intention of the ascetic thus becomes an important factor for distinguishing Jaina ascetics from non-Jaina ascetics or "magicians". In the texts, the overall "religious" orientation is identified as the decisive factor, determining the superior power of Jaina ascetics. Viy 3.6 (191b), for instance, informs us that capable (bhāviya-appa, Sk. bhāvita-ätman) monks can see distant objects via supernatural sight, that is, create a representation of a distant object in their mind; but only the supernatural perception of a righteous (samma-ditthi) monk who is both capable and pure corresponds to reality, not the perception of a non-believing (micchā-ditthi) ascetic, whose powers are weaker due to his fundamental delusion. Similarly, Viy 1 18.10.1 (757a) states that capable monks are able "of moving in the air without support" (Schubring 1935/2000, § 181, p. 318). By contrast, the commentary of TP II.4.1042-1057 describes the capabilities of moving through the air in realistic terms, as based on the support of living beings inhabiting the air ('without harming them').

124 The use of this body is restricted to ascetics of high purity and one particular purpose only:

Unlike other bodies, the conveyance body is very short-lived. When the ascetic has any doubt in his mind about the meaning of a very difficult and obscure issue of the doctrine, he uses the conveyance body, expands his soul into this subtle body, reaches the distant Jina instantly and withdraws to the gross body within an intra-hour (less than forty-eight minutes). The conveyance body is abandoned as soon as the mission is completed (Tatia 1994, p. 60).

125 Schubring $(1935 / 200, \S 57$, p. 126). 
but theoretically quantifiable space points that are occupied by a particular substance. ${ }^{126}$ All substances exist in space and are formless (arūva) and hence invisible, with the exception of matter which has a tangible form (rüva) (Viy. 1.10).

Disputed is in classical Jaina philosophy the question whether time $(k \bar{a} l a)$ can also be categorised as a substance or, if not, what its ontological status could be. ${ }^{127}$ The question boils down to the conundrum whether time, like the other five substances, can be reduced to space (as in conventional linear representations of time) or whether it exists only in form of singular discontinuous moments. ${ }^{128}$ Most Digambara philosophers argue that time is a substance, because it has auxiliary transformative functions. ${ }^{129}$ In their view, the causative function of time alone explains both the continuation of a particular substance over a certain period and its final disappearance. Hence, it should be declared to be a substance $\left(\mathrm{TS}_{1,2} 5.22 \&\right.$ $\left.5.49, \mathrm{SaSi}_{1} 569 \& 357\right)$. Śvetāmbara authors deny this. They argue that because time has no extension in space (like the other formless substances) it cannot be a substance. Time exists only in the form of unconnected moments. A compromise in terms of the two-truth theory is offered by $\mathrm{SaSi}_{1} 569$ which distinguishes between conventional (sequential) time (vyavahära-kāla) and absolute (momentary) (paramartha-kāla) time, as two different perspectives on two principal aspects of time.

Perspectivism is at the heart of classical Jaina ontology. For classical Jaina philosophy, encapsulated in the famous tripadi formula of $\operatorname{TS}_{1(2)} 5.29(5.30),{ }^{130}$ which Ācārya Umāsvāti created to encompass competing eternalist Hindu and temporalist Buddhist ontologies, existence (sat) is constituted by the three causative modes of origination (utpāda), persistence (dhrauvya), and cessation (vyaya). From the perspective of substance (dravya) everything that exists is eternal, i.e., is constituted by imperishable elements, but from the perspective of mode (paryāya) everything that exists is forever changing. A difference of opion concerns the mediating concept of guna which designates the persisting qualities that distinguish different substances or entities. In contrast to the standard Śvetāmbara position, expressed in Utt 28.5 and $\mathrm{TS}_{1} 5.37$, that a substance is constituted by both qualities and modes, the Śvetāmbara Ācārya Siddhasenadivākara (STP 3 III.8ff.) argued that the terms guna and paryāya are synonymous, as did Ācārya Malayagiri. ${ }^{131}$ Ohira (1994, p. 92) pointed to the significance of the concept of guna for the theory of material transformation (parināma) cum motion through processes of atomic

\footnotetext{
126 Ohira (1994, p. 99f.), who accomplished her work under D.D Mālvaniyā, offers a theory of the evolution of the theoretical concept of pradeśa (from vpra-dīs, to manifest), the "cause of perceptibility", starting with the word a-pradeśa, non-indication, non-determination, to indicate the invisible nature of the atom.

127 Pūjyapāda $\left(\mathrm{SaSi}_{1}{ }^{569)}\right.$ and other Digambara commentators on TS 5.22, a verse on the concept of transformation (paranāma), characterize time in terms of the qualities of non-sentience and immateriality.

${ }^{128}$ Cf. Heidegger (1918-1919/1995, p. 307, etc.), for deliberations on similar questions.

${ }^{129}$ Not as a material but as an instrumental cause: nimitta-kārana

130 sad dravyalakșanam |

utpāda-vyaya-dhrauvyayuktam sat I

Existence is the character of a substance.

Origination, cessation and persistence constitute existence. $\left(\mathrm{TS}_{2}\right.$ 5.29-30)

131 See Mālvaniyā (1971, p. 246).
} 
attraction and repulsion, "by the degrees of gunas existing in matter itself", 132 which may be one reason for its incorporation in the classical dravya-guna-paryāya sequence.

\section{Modes of Material Transformation}

The Jaina concept of continuity through change is further theorised under the title of parināma or transformation of substances of entities in P 13, Viy 1 1.1.3 (23a), 1.3.4 (55a), ${ }^{133}$ etc., and $\mathrm{TS}_{1} 5.41$ in particular; both with regard to material atoms (pudgala) and aggregates (skandha) and to living entities. ${ }^{134} \mathrm{Viy}_{3} 14.4 .52$ states that there are two types of transformations: of animate beings (jīva-parināma) ${ }^{135}$ and of inanimate beings (ajīva-parināma). The theory of transformation is both the foundation of classical Jaina karman theory and of the Jaina theory of matter. The locus classicus for the concept of parināma in Jaina philosophy is Viy 8.1. ${ }^{136}$ Ohira (1994, p. 56) places this chapter and all thematically similar texts of the Viy. in the fifth and last canonical stage of her scheme (4th-5th century C.E.), having located the first appearance of the theory of pudgala-parināma in the second or third centuries C.E. (ib., p. 93). All modern commentators agree that the theory of transformation is late-canonical.

Viy $_{1,3}$ 8.1.1 (328a) ${ }^{137}$ distinguishes three types of material particles (poggala) and Viy $_{1,3} 8.1 .2$ (332b) similarly three types of individual entities (davva) ${ }^{138}$ with reference to distinct modes of transformation-natural, karmic and mixed-that produced them ${ }^{139}$ :

\footnotetext{
132 Cf. the Vaiśeșika solution by postulating karman as an independent category of motion. See Ohira (1994, p. 92).

133 "This atthittam atthitte parinamai [= the attribute being existent remains if the entity undergoes

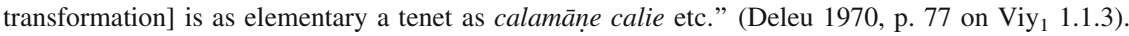

${ }^{134}$ See Ohira (1994, p. 99) on the contrast between Jaina parinamavāada, which emerged in the "third canonical stage" and the Vaiśeșika position that existence becomes non-existence after the desctruction of an entity in Vaiśeșikasūtra 9.2.

The practical implications of the once dominant Jaina perspective that atoms change while being changed are illustrated by Jaina critical analysis of the powers of transformation of gods, for instance in Viy $_{1} 16.5$ (704a-708b).

135 The term jīva is ambiguous. In its embodied form it is seen "as somehow indistinguishable from the body" (Ohira 1994, p. 110).

${ }^{136}$ For the sources on parināma, see Vijayarājendrasūri 1913-1925/1986 V: 595-614, and on prayogamiśra-viśrasā parināma parinatah pudalah pp. 602-610.

137 In identical words: Ṭhāna ${ }_{1}$ 3.3.401.

138 A particular object is also called dravya albeit being a "substance" of "a second order" (Schubring $1935 / 2000, \S 61$, p. 136). On the multiple meanings of the term dravya in Indian philosophy, see Halbfass (1992, p. 89f.).

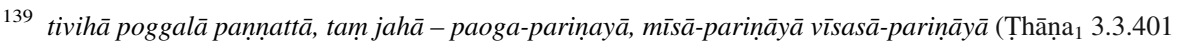
$=\mathrm{Viy}_{3}$ 8.1.1).
} 
1. Transformed by external (karmic) impulse (paoga-parinaya, Sk. prayoga-parinata),

2. Transformed by mixed causes (karmic \& natural) (missa-p., Sk. miśra-p.),

3. Transformed spontaneously (naturally) (vīsasā-p., Sk. visrasā-p.). ${ }^{140}$

The term prayoga-parināma, transformation by external impulse, designates changes that are brought about (consciously or unconsciously) by the action of the embodied soul. According to classical Jaina doctrine, this form of karmic causality produces the five bodies of living beings. ${ }^{141}$ Visrasāa-parināma, spontaneous transformation, designates the processes of natural (svabhāva) transformation of inanimate atoms, such as aggregation, disaggregation, etc., independent of any interference of embodied consciousness. ${ }^{142}$ According to $\mathrm{Viy}_{3}$ 8.1.27, 8.10.467, spontaneous transformation affects the colour, smell, taste, touch and shape of matter. ${ }^{143}$ In $\mathrm{P} 13$ the term parināma refers to natural processes of atomic aggre-

140 I follow the terminology of Schubring (1935/2000, § 60, p. 133-136) and Deleu (1970, pp. 145, 154, 206), who also uses "instrumental and automatic process[es]". Since action (karman) involves conscious and unconscious processes, Lalwani's (1980 III, p. 103) (Viy 6 8.1.1) translation "conscious transformation" is merely a shortcut.

141 Viy $_{5}$ 8.1.50-71 explains how various permutations of karmic activity result in different material transformations. The gross physical body, for instance, is transformed by conscious physical activity (kāya-payoga-parinaya), resulting in bodies of different degrees of purity (Viy $5.1 .55 \mathrm{ff}$.) and power (vīrya-śakti) (Amar Muni, commenting on Viy 5 8.1.71). "This threefold activity [paoga]", of mind, speech and body, though considered to be material, "is considered to be of the soul (ātmavyāpāra) because it does not take place in its absence" (Mālvaniyā 1971, p. 345). Different interpretations of the term prayoga, principally treated in $\mathrm{P} 16$ in the canon and under the title prayoga-karma in the Digambara Șațkhaṇ̣̂āgama (ib.), have influenced the available translations. Paoga-parināma was translated by Amar Muni as "conscious transformation" (Viy 5.1 , p. 468), while Schubring (1935/2000, $\S \S 60,61$, pp. 133, 136) and Deleu (1970, pp. 120, 206, 237), preferred the neutral formulation "'accidental' change" (parināma) caused by an "impulse from without", that is, karman, an "instrumental process" of mind, speech and body (Viy ${ }_{1} 1.3 .3$ [254a]).

Mahāprajña's commentary (ViyBh 8.1.1) to Viy $_{4}$ 8.1.1 (III, p. 6) summarises divergent interpretations of this passage:

Umāsvāti in his Bhagavatīvrtti 8.1 focuses on the three different causes of the bondage of material atoms constituting the structure of the molecules of a physical body: 1. prayoga: effort of the soul (jivvavyāpārena śarīrāditayā parinatāh), 2. miśra: a combination of both, 3. svabhāva: nature.

Siddhasenagaṇin in Tattvārthabhāṣyavṛtti (TBV) 5.17 relates the three types of transformation to the Jaina teaching of the three causes (kārana): 1. material (parināma) ("=upādāna"), 2. final (nirvartaka), 3. instrumental (nimitta); different from the Vaiśesika triad of causes: 1. inherent (samavāya), 2. noninherent (but closely related) (asamavāya), and 3. instrumental (nimitta). Cf. Potter (1997, p. 55-57).

Siddhasena Ganin defines prayoga also as the action of the embodied soul (TBV 5.24: prayogo jivvavyāpāras tena ghațito bandhah prāyogikah).

The Digambara philosopher Akalankka, by contrast, in his Tattvārtharājavārtika (TRV) 5.24, understands it as designating the union (samyoga) of the human body, speech, and mind (prayogah purusakāya-vād-manah samyoga-lakșanah).

142 Dual causality of nature and karman is well established in Digambara literature as well. See $\mathrm{SaSi}_{1}$ 529-531.

143 pamcavihe poggala-parināme pannatte, tam jahā-vanna-parināme, gamdha-

pariṇāme, phāsa-pariṇāme, saṃthāna-pariṇāme \| (Viy $\left.{ }_{3} 8.10 .467\right)$.

Frequent implicit references to the Paṇnavanā $(\mathrm{P})$ I \& XIII are made in the sections on matter in Viy. 8.1 \& 8.10, Viy. 14.4. See Deleu (1970, pp. 145, 206f.). 
gation, disaggregation and movement. ${ }^{144}$ Miśra-parināma, mixed transformation, finally, refers to a combination of karmic and natural processes. ${ }^{145}$

According to $\mathrm{Viy}_{3} 8.1 .40-41$, miśra-parināma produces the five bodies of living beings in a similar way as prayoga-parināma. Since both karmic and mixed causes are involved in the formation of the five bodies of living beings (Pk. käiya) Viy $_{3}$ $8.1 .27,8.1 .40 f$.), the question emerges what exactly the difference between these two forms of transformation is? An indirect answer is given in Viy 3 8.1.43 which states that any particle or aggregate can be transformed karmically, naturally or in both ways combined. Most objects in the world are the product of natural transformation, followed by products of mixed transformation and finally products of karmic transformation $\left(\mathrm{Viy}_{3}\right.$ 8.1.84). If more than one particle or entity is involved, as in processes of aggregation, then the products of three types of transformation

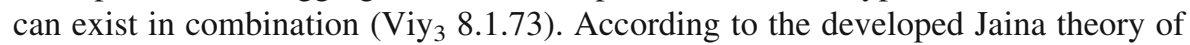
karman, effectively all living entities are constituted through mixed processes of transformation. Glasenapp (1915/1942, p. xix) called attention to the fact that the summary Karmagranthas of the Śvetāmbara Ācārya Devendrasūri give however only an evasive explanation of how natural processes further differentiate the karmic particles which were attracted by the actions of the living being in such an ingenious way that complex organisms emerge:

I am aware of only one passage wherein the author deliberately raises the question concerning the cause. It is contained in $\mathrm{Kg}$. II., 75a; herein the author raises an objection as to how it is possible that the particle of matter seized in a moment by the soul is capable of transforming itself into the number of particles necessary for the formation of the various species of the karman, whereupon he replies that it is performed through the mysterious power of the soul, of which we may not make to ourselves any idea, and through the peculiar quality of the matter itself. It may be observed, he argues, that matter on which no spiritual force is working, is changing into clouds and rainbows; why then could not matter with which a jiv $a$ is in connection be changed into different kinds of karman? All further discussion is cut off by an energetic 'alam vistarena'.

A related question is whether processes of karmic and mixed transformation apply only to matter forming the body of living beings or also to inanimate matter outside the body? This question, which touches at the heart of the conundrum of the status of 'sacred matter' in Jaina philosophy, is not clearly addressed in the Viy. itself, but was taken up by the commentaries. The term miśra-parinata is explained in somewhat greater detail in Viy ${ }_{5}$ 8.1.46-47 and 8.1.72-73, but remains controversial in the commentary literature. ${ }^{146}$ Different opinions are recorded in modern refer-

\footnotetext{
144 See Schubring $(1935 / 2000, \S 60$, p. 133).

145 Schubring $(1935 / 2000, \S 61$, p. 136) comments on this passage: Material masses of this kind [inanimate aggregates], together with their shapes, come into being spontaneously, whereas all accumulations furnishing the souls in the world with bodies and opportunities of activity ... result from impulse, i.e., through the working of the Karman. But as these accumulations have concrete qualities, it follows that they represent a mixture of both cases (Viy. 332a).

146 For the following, see Mahāprajña's summary of the commentaries: Viy ${ }_{4} 8.1 .1$, pp. $5 f$.
} 
ence works. Ratnacandra (1923/1988 IV, p. 179f.) defines mīsa-parinaya poggala as a "molecule which has matured into a mixed state, i.e. has left the soul but has not yet assumed another form". Deleu (1970, p. 145), by contrast, states unambiguously that it is only the "animate world" which results from conscious and mixed transformation. Natural transformation affects only colour, smell, taste, touch and shape. The assessment of the scope of the category of the miśra-parinata pudgala varies even more widely in the classical commentaries. In the older commentaries the paradigmatic examples for products of mixed transformation are material objects outside the body which have been transformed by the activity of living beings who worked on them. In the later commentaries dead bodies or body parts of living beings are cited as examples; that is, either products of mixed transformation within the living organism or products of a two-step sequence of karmic transformation within the body followed by natural transformation outside the living organism. Thus, not only organic-cum-inorganic matter ${ }^{147}$, but also inorganic matter that had once been transformed by the activity of living beings and was then ejected is categorised as a product of mixed processes of transformation.

The Digambara Ācārya Akalan̉ka (8th century) in his Tattvārthavārtika (TV) 5.24 does not accept mixed transformation as an independent category. Instead, he distinguishes two sub-types of karmic transformation (prayoga-parināma): of nonliving entities (ajivva-visaya) (for instance wood covered with shellac) and of mixed living-and-not-living entities (jīvājīva-visaya). ${ }^{148}$ Akalañka further differentiates two types of the latter: karma-bandha and nokarma-bandha, that is, processes of binding particles that form the karmic body (kärmana-śarīra), on the one hand, and processes of binding particles of the gross-, transformation-, transposition- and fiery bodies, on the other hand. The same example of wood covered with shellac for the transformation of non-living matter was selected later by the ca. ninth century Śvetāmbara Ācārya Siddhasenaganin in his Tattvārthasūtrādhigamabhāṣyavrtti (TSB) 5.24. Siddhasenaganin, however, does accept 'mixed-transformation' as a separate category and explains miśra-parinata with reference to the examples of the pillar (stambha) and of the water pot (kumbha) which are both created by a combination of naturally produced clay and form-giving human activity. ${ }^{149}$ Siddhasenaganin and Akalanka both agree that 'mixed-transformation' applies only to objects outside the living body if they are shaped not only by natural processes but additionally by the actions of living beings.

The Mūrtipūjaka Ācārya Abhayadevasūri (11th century.), by contrast, in his Sanskrit commentary Bhagavatīvṛtti (ViyVṛ) 8.1, chose as examples for products of mixed transformation (1) the corpses of human beings, etc., that naturally decompose (mukta-kadevarādi-rūpa), and (2) naturally transformed classes of gross, etc., matter (audārikādi-vargañ-rūpa) that are further transformed by the actions of

\footnotetext{
147 Sikdar (1987, pp. 235-237 and 213).

148 TRV 5.24: sa dvedhā aj̄̄va-viṣayo jīvājōva-viṣayaśceti | tatrā'jīva-viṣayo jatukāṣthāi lakṣaṇah |

149 TBV 5.24: prayoga-visrasābhyām jīva-prayoga-sahacaritācetana-dravya-pariṇati-lakṣanah stambha-kumbhādi-miśrah I
} 
living beings. ${ }^{150}$ The Sthānakavāsī Pravartaka Amar Muni interpreted the text as follows:

Jointly transformed matter - This is of two types - (1) naturally transformed matter without disintegration of the consciously acquired form, such as a corpse. (2) Naturally transformed species of karmic particles, such as those needed to form the gross physical body etc., further transformed consciously, such as the gross physical body of a being (ViyVr, according to Amar Muni, Viy $_{5}$ 8.1, Vol. 2, p. 468; Translation from Hindī by Surendra Bothra).

The two complementary processes envisaged here are, first, the ejection of karmically transformed matter from the soul and the subsequent natural transformation, and, second, the reverse process of attraction of naturally transformed matter and its further karmic transformation by an embodied soul building up its bodies. ${ }^{151}$ In the first case, the transformative actions of living beings are followed by processes of natural transformation. In the second case, processes of natural transformation are followed by actions of living beings.

For Abhayadevasūri it is quite clear that atoms and molecules that form the material body of an acting living being (jiv $a$ ) are also subject to processes of natural transformation. Our question, what exactly the difference is between karmic and mixed transformation is answered by him as follows. The transformation through action (prayoga) also involves processes of natural transformation (visrasā), and in this sense can be considered as a form of mixed transformation. But natural transformation is not essential (vivaksita) in this context. However, in processes of mixed transformation both prayoga and visrasā are essential. The same point was made already by Siddhasenaganin (TBV 5.24), who argued that the question about the way in which the two processes are combined cannot be settled in abstract terms, but only with reference to a particular context. In processes of transformation through action, the innate effort (samavāya-kārana) of the living being alone is sufficient. No external instrumental cause (nimitta-kärana) is necessary. In processes of mixed transformation, an additional external cause is always necessary. Processes of natural transformation, on the other hand, are indifferent (nirapeksa) to both the inherent cause and the instrumental effort of living beings. ${ }^{152}$

\footnotetext{
150 miśraka-parinatāh prayoga-visrasābhyāh parinatāh | prayoga-parināma-matya-janto visrasayā svabhāvāntaram āpāditāh mukta-kadevarāंdi-rūpāh | athav-audārikādi-varganāa-rūpā visrasayā niṣpāditāh santah jūva-prayogen-aikendriyādi-śarīra-prabhrti-parị̄āmam āpāditās te miśra-parinatāh nanu prayoga-parināmo’py evam-vidha eva tatah ka eșām viśeșah? satyaṃ; kinnu prayoga-parinateșu visrasā satyapi na vivakṣitā | (Viy Vṛ 8.1).

151 Cf. Sikdar (1987, p. 327).

152 Siddhasenaganin notes that the process of transformation through inherent causes (samavāya-kārana) can be related to concepts of Vaiśeșika philosophy (ViyBh 8.1.1). See supra for Abhayadeva's reinterpretation of "samavāya-kārana" in the sense of "combined causes" in his TVB.
} 


\section{Dead Bodies and Relics}

Viy. 8.1 does not discuss the ontological status of dead bodies. ${ }^{153}$ Yet, as we have seen, at least one of the significant commentators, Abhayadeva, points to the dead body as a paradigmatic example for an object produced by mixed karmic and natural causes. Following on from this, I would argue that body parts such as relics can similarly be conceptualised from the perspective of classical Jaina philosophy as material objects which were created by mixed karmic and natural causes. The distinction between insentient matter in general and the matter of dead bodies and relics is that the physical structure of the latter is the product not of natural but of mixed causes of transformation. In fact, it could be argued that from the perspective of classical Jaina philosophy, the material qualities of bone relics differ from qualities of inorganic matter outside the body in a similar way as organic chemical compounds were in Europe once believed to differ from inorganic compounds, until experimental counter evidence was furnished by Friedrich Wöhler in $1828 .{ }^{154}$ The relics of Jaina mendicants are special, however, because the material aggregates resulting from ascetic processes of transformation are ideally predicated entirely on wilful instrumental action and hence differ in structure from aggregates that underwent unchecked processes of mixed transformation. Effectively, two types of relics produced by mixed natural and karmic causes are distinguished. ${ }^{155}$ In contrast to the matter of common dead bodies, which is shunned, the relics of Jaina ascetics are considered valuable because material results of exemplary renunciatory action are in part crystallised in the living bodies as well as in the remaining dead matter. ${ }^{156}$ The bodies and body parts of advanced Jaina ascetics, it is believed, are not constituted by ordinary organic compounds, but by extremely refined matter, like the body secretions and other material particles that are ejected from the ascetic body. Jaina mendicants compare the beneficial physical properties of ascetically distilled "auspicious matter" such as body secretions and physical remains with the properties of medical pills. ${ }^{157}$ In contrast to body secretions, the physical qualities of ascetically produced body relics last for some time even after the severance of the gross body from the soul at the point of death.

\footnotetext{
153 It refers however to cases of mixed bodies (missa-sarīra), and of conscious or mixed transformation of gross (etc.)-cum-mixed bodies (orāliya-mīsāa-sarīra-kāya-payoga/mīsā-parinae) (Viy 3 8.1.49) (etc.).

${ }^{154}$ See Sikdar (1987, p. 237f.). In modern science, the notion of 'organic compounds' is still used as a shorthand for certain shared qualities of plant and animal produce, such as the presence of carbon.

155 Cf. the third of Laidlaw's (1995, p. 242f.) three styles of Jaina usage of the body, especially the 'iconic' style: (1) 'Indexical' - 'normal' use of the body for the simultaneous pursuit of renunciatory and worldly ends; (2) 'Dualistic' — attempt to destroy the body in order to liberate the soul; (3) 'Iconic' representation of the perfect body as an expression of inner purity. Laidlaw's categories do not form a logical continuum, and indexical and iconic features are not clearly identified in the text. The dualistic path is not "largely" a Jain lay project (ib., pp. 152, 238).

156 The results of action come to fruition mainly in the process of reincarnation determined by the karmic body.

157 Personal communication of the Terāpanth mendicants Samaṇi Caitanyaprajñā, London 5.9.2008, and Muni Mahendra Kumār, Lādṇụ̄ 22.12.2009. Cf. Friedrich (1943, p. 220) on the medical use of pills made of the bones of Tibetan Lamas.
} 
The fact that the different types of dead matter that are distinguished (or distinguishable) in Jaina philosophy have apparently not (yet) been valorised in this way in official Jaina culture, despite the evident options in Jaina ontology, can only be explained by a historical combination of soteriological and social factors. The question of the historical function of the relics of renowned ascetics in Jaina culture can however not be addressed in this article. ${ }^{158}$ From a strictly karman theoretical perspective, the material products of ascetic labour may be special and even beneficial for the material wellbeing of living creatures, yet, they can in no way affect the soteriological prospects of the devotee which are entirely determined by his or her own renunciatory practice.

\section{The Material Qualities of Bone Relics After Cremation}

The main argument of this article is that, technically, not only dead bodies but also bone relics of venerable saints, though apparently not mentioned in the commentaries to Viy. 8.1 and 18.3.2 ${ }^{159}$, belong to the Jaina category of matter formed by mixed karmic and natural causes. The two main transformative processes involved in the production of bone relics are: (a) attraction of exterior matter and constitution of the body through karmic activity and natural causes, (b) death, dissociation of the soul, and either natural decomposition or cremation of the gross body.

An important question is how cremation affects the quality of the physical remains. From the late Vedic period onwards, the process of decomposition of dead bodies was deliberately accelerated through cremation by the majority of the population in South Asia who could afford it. After the incineration of the corpse and the cooling of the ashes, the remaining more or less preserved charred bones (atthijhäma) were collected and disposed either on the spot or at 'sacred rivers'. These practices continue even today. What kind of material qualities can be attributed to the charred bones and ashes that remain after cremation from a Jaina philosophical perspective? In which way does the deliberate process of incineration, which itself is of mixed karmic and natural causality, transform the physical structure of the body?

Viy $_{1}$ 1.2.2 (213a) tells us that this very question was once put to Mahāvīra by his chief disciple Gautama. Mahāvīra explained that the burning of all physical substances is a process of transformation of matter attracted by fire beings (tea-kāya) with the help of wind-beings (vāu-kayya), both of which are conceived as living creatures in classical Jaina doctrine ( $\mathrm{Viy}_{1} 16.1$ [213a]). In the process of cremation, the dead bodies that originally belonged to mobile beings become the bodies of fire beings:

[Q.] Bhante! To what category of living beings do the bodies of bone, burnt bone, skin, burnt skin, pelt, burnt pelt, horn, burnt horn, hoof, burnt hoof, nail and burnt nail belong?

${ }^{158}$ Cf. Flügel (2010b).

159 A comprehensive review of the Jaina commentary literature is beyond the scope of this study. 
[Ans.] Gautam! Bone, skin, pelt, horn, hoof, nail these are all bodies of mobile beings (trasa jiva). Burnt bone, burnt skin, burnt pelt, burnt horn, burnt hoof, burnt nail are the bodies of mobile beings in terms of their earlier or original state. After that when they are processed with implements and so on up to $[j \bar{a} v a]$ fire and undergo transformation they may be called bodies of firebodied beings ( $\operatorname{Viy}_{5}$ 5.2.15, translated from Hindī by Surendra Botharā, cf. Viy $\left._{8} 5.2 .53\right) .{ }^{160}$

The same answer is given in $\mathrm{Viy}_{5} 5.2 .16$ in reply to the question as to the nature of ashes (chāriya) and other materials fuelling fire, such as cowdung, etc. Similarly, DVS 5.1.7 stresses that a monk should not step on warm ash and other forms of matter recently touched by fire to avoid killing life in the form of fire beings. ${ }^{161}$ Cold ash, by contrast, is considered to be dead ${ }^{162}$, and is commonly used by to prevent bleeding in the ritualised periodic plucking of hair and beard (kesa-loya) that is obligatory for Jaina mendicants. ${ }^{163}$ For Jaina philosophers there was no doubt that the remains left by the cremation fire were aggregates of dead matter; at least for a short period after the flames have died down and before new souls start repopulating the material remains. Within a period of one muhutta, that is, less than forty-eight minutes ${ }^{164}$, it is said, dead matter, such as ash, may be repopulated by living souls. In their process of decomposition, bone relics, too, should be able to function as hosts for reincarnating souls and become one-sensed beings (like fire, even stones can be living entities), though no text known to the present writer seems to have dealt with this question. If this is not the case, then a further explanation of the exceptional status of bone and tooth relics, which decompose only slowly, would have been found. ${ }^{165}$

The reliable production of relics is predicated on the practice of cremation, and the aim to produce relics may have been one of the reasons for the introduction of the practice of cremation for prominent saints at least in the case of Buddhism as

\footnotetext{
160 The Jaina theory of transformation of ever changing modes of eternal atomic particles in the act of incineration differs from those of the Vaiśeșika and Naiyāyika philosophies, as Sikdar (1987, pp. 300309) and Mahāprajña (ViyBh 5.2.51-54) have pointed out. The Vaiśeșika philosophers assume that in the process of baking for instance all individual atoms ( $p \bar{l} l u-p \bar{a} k a)$ are destroyed and recreated in a new form. Naiyāyika thinkers, by contrast, posit that the changes affect the whole body (pițara-pāka). The individual atoms remain the same in the process of baking, but are mixed with fire particles which accounts for the transformed appearance.

${ }^{161}$ For Vedic views on the fire hidden in the ashes, see Krick (1982, p. 122).

162 For Manu 13.97 , etc., "dead ash" has negative connotations, since it implies the extinction of the lifegiving fire. One should not step on it: "A person who wants to live a long life will avoid stepping on hair, ashes, bones, skulls, cotton seeds, and chaff" $\left(\mathrm{Manu}_{1} 4.78\right)$. Hair represents fertility and vitality crossculturally. This is also the case in the Vedas. See Krick (1982, p. 88f.).

${ }^{163}$ Water mixed with cold ash is considered to be dead and therefore acceptable for mendicants because of the chemical reaction, not because ash is associated with fire. Because water is killed by ash (fire), some Jains believe it to be wrong to immerse the bones and ashes that remain after cremation into rivers. ${ }^{164}$ Ratnacandra (1923/1988 IV, p. 193) explains that a muhürta equals two ghadīs or 3,773 breaths.

$165 \mathrm{~K}$. Wiley (personal communication 1.11.2010) remains sceptical: "This would relate to the operation of nirmāna nāma karma in association with jāti nāma karma. In other words, a soul taking birth as an earth-bodied being would form various sorts of bodies, but not one that has the qualities or shape of a 'bone'”. See also Friedrich's (1943, p. 201f.) discussion of the unique physiology of bones.
} 
suggested by the famous account of the funeral of the Buddha in the Mahaparinivvā -nasutta. However, cremation was not always practiced, certainly not amongst the Nigganthas. Canonised scriptures such as the Śvetāmbara Kappasutta and its commentaries and the Digambara Bhagavatī Ārādhanā describe the ways in which corpses of dead ascetics should be discarded in the wilderness and left to the wolves and vultures, which disperse the remaining fragents of bones in all directions. The comparatively slower process of physical decomposition is also described as staged. The matter produced by five-sensed living beings is re-transformed by karmic activity of one-sensed beings and hence loses many of its previous qualities. As a result of this process of transformation, after a while, a different type of dead matter remains.

The power of one-sensed living beings (egimdiya) is, of course, limited and cannot explain the extraordinary energy attributed to relics. ${ }^{166}$ Nevertheless, even in their decomposed or cremated form, as physical matter, certain fragments of the body parts created by the actions of the ascetics retain some of their original material properties and hence are said to have healing qualities, like a pill produced by Ayurvedic medicine or the pharmaceutical industry. ${ }^{167}$

\section{Enduring Power of Body-Parts Outside the Body and Transfer of Power}

Another question is how these properties, if indeed they exist, can be transferred to or appropriated by another living being? No satisfying answer, it seems, can be found in the Jaina texts. Evidently, dissociated karmic particles automatically loose their quality as karmic matter once severed from the embodied soul: "Karmic particles thus purged are mere matter particles (pudgala) devoid of karmic efficacy" (Ohira 1994, p. 196). The question whether karmically transformed matter also immediately loses its powers after being disconnected from the body is disputed within the (Śvetāmbara) Jaina tradition. The concept of the special power of disembodied body parts of ascetics would otherwise play no role. Contrary to this view, it is stated in Viy $_{1} 14.4(638 \mathrm{a}-641 \mathrm{a})=\mathrm{Viy}_{3}$ 14.4.44-53 that because atoms are eternal (sāsaya) only from the point of view of substance but not eternal from the point of view of mode (colour, etc.), they revert back to their original state once a particular transformation (parināma) has been accomplished. Once the atom is reset to its original state a new transformation can start. The same applies to molecules (khamdha), that is, aggregates of material atoms (in this context called paramānu-poggala), which (can) combine to form individual objects (davva). After the completion of a particular transformation they, too, revert back to their original state. The fact that aggregates will, at some stage, decompose into their elements is

\footnotetext{
166 See Wiley (2000, p. 125).

$167 \mathrm{Uv}_{1}$ 159, however, mentions imperfect Jaina monks (samana) who hand out ashes which miraculously cause wellbeing (bhüi-kammiyā). Cf. Strong (2004, pp. 10-12) on the distinction between "bones and beads" prevalent in contemporary Buddhism in South East- and East Asia (but not in the Pāli canon). He argued that these beads could be interpreted as "the result of a process of metamorphosis brought on not only by the fire of cremation but also by the perfections of the saint (in this case the Buddha) whose body they re-present". On the process of transformation of 'bones' into 'beads' brought about by the cremation fire see also Granoff (2008, p. 60).
} 
discussed separately in the texts. ${ }^{168}$ The notion of an original unmodified state of an eternal elementary atom with specific qualities (colour, smell, etc.) is, of course, a theoretical limiting case.

\section{Perception and Reappropriation of Karmically Transformed Particles}

It is an open and from the now dominant doctrinal Jaina point of view undoubtedly heretical question whether disembodied ascetically refined particles (poggala) can be perceived and re-appropriated by another living being. ${ }^{169}$ This interpretation seems however to inform Viy $_{1}$ 18.3.2 (740b) $=$ Viy $_{2}$ II.18.3.8-9, a passage summarised by Deleu (1970, p. 237), which tells us that "when a monk who has cultivated his spiritual faculties dies ... the subtile ultimate particles of his karman (je carima nijjarā-poggalā suhumā) spread over the whole world (savvam logam pi nam ogähittānam cițthanti)" through the process of ejection (samugghāya) of the remaining karmic particles. Human beings who are conscious (sanni) and attentive (uvautta) and Vemāniya ${ }^{170}$ gods that are attentive and fully developed (pajjatta) ${ }^{171}$ "can discern and attract (jānanti pāsanti āhāranti) these particles", but not "imperfect" human beings (chaumattha-manussa). ${ }^{172}$ The second part of this statement specifies that highly developed Jaina mendicants can and apparently wish to "attract" the final highly purified particles ejected by the soul of an advanced dying Jaina monk. By contrast, particles which are attracted by a living being but not bound and immediately ejected (nijjarā-poggala) are said to be without form $(r \bar{u} v a)$ and hence intangible $\left(\mathrm{Viy}_{1} 18.3 .5[743 \mathrm{~b}]\right) .{ }^{173}$

A detailed discussion of the question of the perceptibility of dead karmic particles which are ejected during the process of samugghaya (which not every living and omniscient being undergoes) is offered in $\mathrm{Uv}_{1} 169-180$. Schubring (1935/2000, $\S 89$, p. 184) refers in this context also to $P$ 590a and 496a f. (his manuscript), which considers with regard to an imperfect individual "whether and to what degree the ejecting individual has committed actions to other beings to whom they [the particles] cause an injury". He argued that "[t]he whole conception doubtlessly comes from the impression which pain, anger, curse and blessings cause within the onlooker" (ib., p. 185). ${ }^{174}$

\footnotetext{
${ }^{168}$ See ViyBh 14.4.44-47. Ohira (1994, p. 56) points out that in the summary of the theory in Viy. 14.4 it is stated that when the process of transformation (parināma) of matter from one state to another as such comes to an end, a pudgala or skandha "returns to the state of an atom of one colour, etc." (ib.).

169 As the above cited English translation of Amar Muni's comments on ViyVr, 8.1 suggests.

${ }^{170}$ Like humans, Vemāniya gods are either untruthful and/or heretical or not, as explained in the text.

171 The term pajjatti (Sk. paryāpti) refers to the six powers of the nāma-karman of the embodied soul (âtmā- śakti) to attract and transform different material atoms constituting basic functions of the physical body: āhāra, śarīra, indriya, śvāsocchvāsa, bhāșā, manah. See SAS 8.11 .

172 Deleu (1970, p. 237) refers in this context to P 590b, 596a ff. (Āgamodaya-Samiti Edition) for further details on ejected particles.

${ }^{173}$ Deleu (1970, p. 238) points to Viy 7.10 .1 (323b) in this context, where Mahāvīra explains to Ājīvika heretics that "bad deeds get their karmic retribution ... only in the living incorporated soul, not in matter". Cf. P 590b, 596a ff., Deleu (1970, p. 212), Schubring (1935/2000, § 60, p. 134).

${ }^{174}$ Compare the debate on the concept of vaira in early Jinism (Jainism).
} 
The commentaries show that the question of the quality and fate of ejected karmic particles preoccupied Jain scholastics for centuries. In Viy ${ }_{1,2} 14.9 .2$ (655b) a series of asymmetrical oppositions is used to describe qualities of physical matter from the point of view of their utility for living beings, as being favourable/unfavourable (atta/anatta), pleasant/unpleasant (piya/apiya and maṇuṇa/amaṇuṇna), desirable/undesirable (ittha/anitțha), etc.

Notable is the parallelism to the question of perceptibility of leśya. It is emphasised in $\mathrm{Viy}_{1}$ 14.9.1 (655a) that even an advanced mendicant cannot perceive his own kamma-lessā nor can he perceive his soul other than in its embodied state. Viy 6.9 , by contrast, discusses whether a god with an impure leśya can see the leśya of other gods or goddesses. The answer is no: only a god with a pure leśy $\bar{a}$. In JĀA 103 the same point is echoed with reference to ascetics rather than gods.

The question how subtle lifeless matter can be absorbed and further transformed deserves a separate study. P. Dundas (1998, p. 44) and K. Wiley (2012, p. 185) both pointed to the lack of "any explanation of the karmic processes associated with the powers of healing" in Jaina literature. Wiley (ib.) suspects that "ācāryas were selective regarding the teaching of this material and were hesitant to commit details regarding these powers to writing." Jaina mendicants, however, invariably point to the commentaries on TS 5.20, which describe the positive or negative contribution of matter (pudgala) acting as an instrumental cause (nimitta-kārana) on the body and mind of living beings, if not prevented to do so by the will-power (purușārtha) of the individual concerned.

\section{Final Karman, Final Body}

Interestingly enough, classical Jaina cosmology seems to envisage not only a soteriological path for souls but also a soteriological path for matter from a transformable to a non-transformable pristine existence. We have mentioned already the theory that after a transformation an atom automatically reverts to is original state unless it is transformed again. The conceptual status of the idea of an orginal state of an atom seems to be the functional equivalent of the idea of the pure soul in the realm of matter. But the issue is not entirely clear. In P 10 and Viy ${ }_{1} 8.3 .3$ (365b) the question is treated in terms of the relative location of any object, insentient or sentient, either at the border (carama or carima) of the material world $(\log a)$ to the infinite space of the non-world (aloga) or within (acarama or acarima) the world. A liberated being, or siddha, is an example of such a carama existence of an eternal substance. Abhayadeva's commentary on Viy 1 7.7.3 (311a) describes the omniscient (kevali) as a final body (carima-sarīra). ${ }^{175}$ The context determines the meaning of the word 'final'. Viy 14.4 (638a-641a) ${ }^{176}$ explains that from the point of view of substance (dravya) an elementary material atom (paramānu-poggala) is eternal (acarima), but from the point of view of place (khetta), time (käla), and condition (bhāva) it is not eternal, but either not-final (acarima), that is, in the

\footnotetext{
175 See Deleu (1970, p. 139).

176 Especially Viy $14.4 .3 b$ (640a).
} 
process of being transformed, or final (carima), that is, not ever returning to the form of existence it was part of. ${ }^{177}$

What is final or non-final is relative. According to Abhayadeva, commenting on the general rule exposed in Viy 14.4 (640a), in the special case of a kevalin there are also final atoms which "will never again enter that form of existence after having left it" (Deleu 1970, p. 207). By definition, since at the moment of death, the kevalin leaves samsära as a whole, the eternal physical atoms he leaves behind are final with regard to the modes of time, place and condition, and thus can never be transformed again. At the point of final samugghāya all remaining karmic particles are dissipated throughout the world $\left(V_{1} y_{1}\right.$ 18.3.2 [740b]). The question is whether they are final only for the kevali or for other beings as well. ${ }^{178}$ The texts and commentaries are ambiguous. ${ }^{179}$ Viy $_{1} 14.4$ (640a) and Viy 18.3 .2 (740b) discount the possibility of further transformation only in the case of liberated beings whose karman produced particles cannot be appropriated again and are hence called final or carima sarìra-poggala. ${ }^{180}$

If indeed this feature applies only to the kevalin, then by implication karmically transformed molecules that are ejected or left over by an unliberated soul can be attracted and integrated again by the same soul in another incarnation, and of course by other souls. ${ }^{181}$ This lends indirect support to our hypothesis that Jaina scholasticism, in some passages at least, considers the idea that certain karmically acquired properties can be objectified in disembodied material structures and transmitted and re-appropriated in this form, unless they always revert back to their original form and can only be incorporated in this form. The formulation of the "reset rule" in Viy $_{1} 14.4$ (638a-641a) must have been motivated by questions such as this.

The question, which desirable physical qualities distinguish karmically transformed ejected particles from plain matter and how they can be advantageous to the one who is able to discern and attract such purified matter would require a separate

\footnotetext{
177 Viy $_{1}$ 18.3.3 (740b) distinguishes between the binding of objects (davva) and of the binding of conditions $(b h \bar{a} v a)$. The first occurrs either spontaneous (vissasā-bandha), with or without a beginning, or is brought about by an external impulse (paoga-bandha), resulting in either loosely (sidhila) or tighly (dhaniya) bound karman, The second relates to the binding of primary karman (müla-pagadi) and secondary karman (uttara-pagadi) as the two principal modes (cf. P 5.465b ff.).

178 See supra.

${ }^{179}$ See Schubring (1935/2000, § 89), Deleu (1970, p. 207), referring to Abhayadeva.

180 See Schubring (1935/2000, § 89; 184, n. 1). See also Abhayadeva's comment in ViyVr 14.4.51, summarised by Deleu 1970: 207, that atoms that were ejected (samudghāta) by an omniscient being at the point of death are an exception, since they will never return to their original condition as far as place, time and condition is concerned. They are therefore "final" (carima) in these respects, but not final as far as their substance (dravya) is concerned. See also ViyBh 14.4.51.

${ }^{181} \mathrm{Viy}_{1} 6.104$ [286a] says that only particles that are within range are attracted by embodied souls. In this context, the distinction in Viy ${ }_{1}$ 14.6.1b (644a) between complete- (avii-) and defective material substances $(v \vec{i}$-davva) is also relevant.
} 
study and cannot be answered here. ${ }^{182}$ To this category of ejected particles belongs the so-called final karman (carima kamma) (Viy ${ }_{1} 5.4 .9$ [221b]); mentioned also in $\mathrm{Viy}_{1}$ 18.3.2 (740b) as discussed above. Suffice it to say that the process of intentional selection and attraction of particles refined by others, if indeed it ever played a role in lived religion, cannot be compared with Buddhist style merit transfers, whether conceived in terms of anumodana, empathy, or as a type of exchange where merit functions as a kind of spiritual currency that is transferred by way of offerings to Buddhist monks accompanied by recitations (see Gombrich 1991, pp. 165-181). In the context of Jaina philosophy, the transmission of energy through attraction of particles or continguity is primarily a physical process.

\section{The Excluded Third in Classical Jaina Ontology}

The view that matter itself is the result of karman has been put forward by a variety of philosophical schools in classical India, such as the Buddhist Andhakas (KV 8.9) or the Brāhmanical Advaita Vedāntins, who entirely spiritualised the principle of karman. ${ }^{183}$ A debate, related in Viy 17.101 (323b f.), between Mahāvīra's first disciple Goyama (Gautama) and the householder Kālodāyi (Kālodāyin), who according to Deleu (1970, p. 38) represented a Ājīvika perspective, also concerned the question whether the karmic retribution of bad deeds (pāva-kamma) manifests itself in matter or in the embodied soul. Goyama's answer was that only the soul can generate karmic matter. ${ }^{184}$

Classical Jainism is dualistic, at least on the level of the substances, the elementary building blocks of the universe. Hence, not everything is determined by karman. ${ }^{185}$ This conclusion, reached by the doctrinal debates in the late first millennium C.E., strongly influenced by Vaiśeșika philosophy, is still widely shared in Jaina scholastic circles. The fate of the living entity ${ }^{186}$ is influenced as much by the

\footnotetext{
182 That the karmic particles are very subtle and intangible to the eye (Viy 18.3 .5 [743b]), so that, according to Abhayadeva, only a kevalin, or omniscient being, can discern them, does not affect the basic idea.

${ }^{183}$ See McDermott (1975, p. 429) and Halbfass (1991/1992, p. 327).

184 The remark in Viy ${ }_{1}$ 15.C.8 (680a ff.) that Gosāla asked to be buried (not cremated or simply discharged) is most certainly a polemical pun on his interpretation of karman theory. On Kālodāyi see also Schubring (1935/2000, § 57).

185 This view contrast, for instance, with the stance of the Advaita Vedānta philosophy of Śankara for whom "[t]h whole world ... is itself nothing but a karmic lay" (Halbfass 1991/1992, p. 327). Controversies on karmic determinism are also evident in Buddhist scriptures, such as KV XXI.7 and XVII.1, which records the position of the Andhakas that the results of karman are fixed. See McDermott (1975, p. 431f.).

${ }^{186}$ Cf. Werner's (1996, p. 185) observations on the difference between European and Indic notions of spiritual entities.
} 
given conditions of nature as by its own actions and their consequences. ${ }^{187}$ Even if the parameters of rebirth and death are broadly determined by karman, the precise circumstances are not fixed. ${ }^{188}$ The concept of karma-leśya may have been invented precisely for bridging this gap. Halbfass (1991/1992: 317) in his pioneering article on the subject of competing causalities in Indian philosophy saw Jainism, one of the few Indian traditions contributing to the philosophy of nature, as a "special case" because it "includes even minerals in its horizon of the living". Yet, apart from the fact that on the whole animistic theories are more widespread than naturalistic theories, Jaina philosophy always maintained the independence of the realm of material causality, ${ }^{189}$ cemented by the classical astikaya theory, however much the trend towards the superimposition of "religious and soteriological schemes and perspectives upon biological, zoological, cosmological observations" (ib., p. 320) pulled it away from recognising the existence of inanimate matter for which recognisable empirical examples are hard to find. No doubt, all $5+1$ substances are either sentient or non-sentient, material or non-material. Yet, for all practical purposes the conceptual distinction between inanimate and animate matter is too abstract if not altogether contradictory and the criteria too imprecise to identify tangible objects composed of dead matter. In late canonical texts, the metaphysical distinction between sentient (sacitta) and insentient (acitta) bodies $(k \bar{a} y a)^{190}$ contrasts with a universal animism that is not yet evident in the early Jaina texts, as B. Bhatt (1989, p. 135ff.) has shown. The general attribution of sentience to the material elements of earth, water, fire and wind makes it virtually impossible for mendicants to find a lifeless path or spot, as required by monastic discipline, except by inference based on observed "acts" of "killing", and hence usually only for

187 Glasenapp (1925, p. 404f.). notes (in the Chapter "Magic and Mysticism") that Jaina scholastics, like other Indians, do not see a contradiction between karman and a certain influence of the planets, assuming a deeper inner harmony which can be studied through astrology. An example is the following summary statement by Tatia (1951, p. 220, n. 1):

The doctrine of karman seems to have developed against a number of other doctrines about creation. Some regarded time (kāla) as the determinant factor of creation. Every event occurs in time and hence is determined by time. Others believe in nature (svabhāva) as the determining factor of creation. Things are determined by their own inherent nature. There is nothing, inside or outside, over and above nature, that determines the course of events. This leads to the doctrine of determinism (niyati-vāda). There were others who believed who believed in the fortuitous and accidental nature of the occurrences of events. There were other doctrines as well. (Vide SvUp, I.2. ŚVS, II.52-64). The believers in karman or the unseen potency (adrsta), the after-effect of a good or bad action, regarded these theories as inspired by materialistic tendencies and therefore rejected them as untenable. The Jaina philosophers accord proper place to these doctrines as testified by our experience, while installing karman in the supreme position. Karman is the ultimate determinant of the course of events. Even time, nature and niyati are determined by karman and there is no such thing as fortuitism. These factors, in so far as they are given to experience, are only the expressions of the working of the supreme law of karman. (Cf. STP, II, 53; SVS, II.79-81).

188 Jaini (1979, pp. 115-117) records known problems of Jaina karman theories. For instance that, "[ā]yu [longevity karman] does not precisely determine ... but it establishes a framework or set of limitations within which these can operate (ib., p. 126).

189 In TS 5.23-24 states that interactions between forms of matter cause both changes in natural phenomena, such as clouds, rainbows etc., and the formation and changes of physical bodies as well as their death (TS 5.19-20). Cf. Jaini (1979, pp. 100-102).

${ }^{190}$ See for instance Viy 1 7.7.2 (309b). 
short periods after death. ${ }^{191}$ In practice, conduct is therefore determined by convention, codified by monastic law, not by actual acts of discrimination between sentient and insentient forms of elementary matter. ${ }^{192}$ This particular contradiction has been highlighted by opponents such as the Âjīivikas. ${ }^{193}$ The canonisation of the doctrine of dual karmic and natural causalities in classical Jaina treatises such as the Paṇnavanāa and the later sections of the Viyāhapannatti, which according to S. Ohira (1994, p. 239) "distinguishes the Jaina school from the other philosophical schools", rather presented logical dilemmas functioning as distinctions directri$\operatorname{ces}^{194}$ which generated disagreements and schisms within the tradition and hence were constitutive for Jaina discourse.

In the Jaina tradition, discussions of the relative influence of karmic and natural causality invariably culuminated in the question of the causes of involuntary premature death, ${ }^{195}$ if not explicitly of "sacred matter". In the developed forms of Jaina philosophy these dilemmas were explained away through variants of the twotruth theory. Prior to this sophisticated epistemological solution (or rather: circumvention of the problem), ${ }^{196}$ Jaina philosophers generally posited a third, mixed or neutral structure, mediating between the opposites of the asymmetrical religious code of jīva-ajivva in one way of another. Multiple ambiguities resulted from the interpolation of mediating categories. An example is the double meaning of the fundamental ontological category of jiv $a$, which designates both the "soul" as such and in its embodied, polluted or mixed state as a "living being". 197

Despite concerted attempts to suppress explicit $d v i k r i y \bar{a}$ - and trirāśī-vādas, etc., implicitly "the excluded third" lived on in Jaina ontology. It was merely delegated

\footnotetext{
191 Bruhn (2007, p. 51) stressed that for practical ethics therefore almost only visible living beings are relevant.

192 For similar distinctions between "'Living', natural soil and of soil that is 'dead' ... because it has been worked by digging [etc.]" in Buddhist souces, see Schmithausen (1991, p. 50). The view of universal animism is absent in the oldest surving text (Āyāra I), as Bhatt 1989: 135ff. pointed out (Schmithausen 1991, p. 3, n. 19). On the problem of elementary or small living beings (and its "solution" through the kașāya theory), see also Bruhn (2007, pp. 15f., 19, 24-26 ff., 51ff., 60).

193 "When a monk who has cultivated his spiritual faculties ... walks in the prescribed way ... and a chicken ... or a young quail ... or an antlike insect ... is trodden down ..., he has committed an action in agreement with his religious duties ( [754a], cf. Viy 17.7 .1 [309b]). On the problem of elementary beings and its "solution" through the kașāya theory, see also Bruhn (2007, p. 15f.).

194 See Luhmann (1987) and Flügel (1995-1996, p. 164f.).

195 According to the Buddhist KV VII.7-8 and XVII.2, the Rājagirikas and Siddhatthikas of the Andhaka School held that an arhat cannot have an untimely death (and hence be liberated) before all accumulated karman has come to fruition. For the Theravādins, by contrast, "old age and death ... are partly due to the physical order" and not "properly ... kamma-vipäka". The commentator (KVU VII.8) tries to solve the dilemma by distinguishing clearly between physical and mental results (kamma-vipāka) of action (kamma) (McDermott 1975, p. 426, cf. p. 432).

196 Albert (1968/1991, p. 126).

197 "The early Jainas ... maintained that a jīva is somewhat indistinguishable from its body, but no further thought was given to the nature of jiva" (Ohira 1994, p. 113).
} 
to a secondary ontological level, ${ }^{198}$ and interpreted as the product of the interaction of the two fundamental ontological substances. The question how jīva and ajīva, spirit and matter, can interact in the first place has never been convincingly answered by Jaina philosophy, as Jaini (1979, p. 114) pointed out. K. Bruhn (2007, p. 52) remarked that the notion of a "mixed" (miśra) state is (also) frequently found in later Jaina dogmatics. ${ }^{199}$ The conception of mixed transformation put forward in Viy. 8.1, for instance, shares certain similarities with the terāsiya heresy of Rohagutta who posited the existence of a third principle, nojīva, mediating between life and non-life. However, it is characterised as a "combination" of two sequentially distinct processes, not as an independent third type of process. "Mixed" is here a descriptive and not an ontological category. In his Nanditịkā, the thirteenth century Ācārya Malayagiri details different aspects of the trirāśs theory of the "Ājīvikas", including its application to the theory of standpoints (naya), that is, the postulate that an entity may be "of the nature of substance, of mode, or of both". 200 Without considering the question of the dates of the texts, Basham (1954, p. 275) suspected that the Ājīivikas (like the "Trairāśika Jainas") "seem to have accepted the basic principle of Jaina epistemology, without going to the over-refined extreme of saptabhangi".

Arguably, the most significant "included third" category in classical Jaina ontology is the concept of pradeśa, an elementary individual space unit that mirrors the material atom and the individual soul. It is imagined to be a two-dimensional insentient and non-material square shaped template, which together with other such units forms quantifiable grids that can be occupied by atoms or by entities (dravya) formed by aggregates of material and/or spiritual substances (dravya). ${ }^{201}$

According to classical Jaina doctrine, even the liberated souls possess an individual "body" shaped by the differential numbers of space units they occupy. ${ }^{202}$ At the end of Viyāhapannatti (Bhagavaī) 8.10 (423b), Gauyamā (Gautamā) asks Mahāvīra the question whether a living being $(j \bar{\imath} v a)$ is the possessor of matter

\footnotetext{
198 The principle of the excluded third is also "violated" by the fourth of the sapta-bhangis of Jaina logic. However, the strategy of hierarchisation secured the non-violation of the law of noncontradiction for each level or perspective. A paraconsistent form of logic as proposed by Priest and Routley (1989, p. 17) is not implied. See Flügel (2010a, p. 168).

199 In his commentary on Viy. 8.1, Mahāprajña (ViyBh 8.1) pointed to the distinction between living (sacitta), non-living (acitta) and mixed (miśra) objects in BKB 2693-2697 to distinguish six causes for quarrel:
}

saccitte accitte, mīsa vaogaya parihāra desakahā

sammamnāuttamte, ahigaranamo samuppajje || BKB 2693|

The commentary gives as an example for each of the three: a disciple, his equipment (clothes, begging bowl), and a disciple with his equipment. The commentary explains that the equipment of a monk, though lifeless itself, should never be given away (to laity in particular) because they can become objects for quarrel.

200 NSBh in Weber (1888 II.1, p. 685, n. 4), translated by Basham (1951, p. 274).

201 Technically, it belongs to the substance space. Cf. footnote 17.

202 On the quasi-material concept of the soul in canonical Jainism (can it be conceived otherwise), see Jaini (1979, p. 113f.). ("Just how a nonmaterial thing can in any way interact with a material one is not well clarified. ... Jainas themselves are in fact not absolutely rigid in maintaining the immateriality of the soul") and Johnson (1995, pp. 128f., 262, 304). 
(poggalī) or itself matter (poggala). The answer is that it is both. Finally, Gauyamā asks the same question concerning the status of the liberated soul (siddha): ${ }^{203}$

Question: Bhante! Are the perfected beings pudgali or pudgala?

Answer: Not pudgali but pudgala.

Question: Bhante! Why do you say so ...?

Answer: Gautama! Relative to another living being, a perfected being is a pudgala. Hence so (Translated by Lalwani 1980, p. 298).

Schubring (1935/2000, § 59, p. 132), Deleu (1970, p. 158) and Ohira (1994, p. 113) explained that here two meanings of the word pudgala come into play: "matter" and "individual" entity (material or immaterial). ${ }^{204}$ With regard to the siddha, the word is used "in the sense of an individual soul which is a well known Buddhist term". ${ }^{205}$

Ohira (1994, p. 99) suggested that the Jaina concept of the pradeśa must have been proposed as a solution of the theoretical problem how different substances "can interpenetrate in the minutest space". In her view, without the concept of pradeśa "the doctrine of astikāyas could not have been formulated" (ib., p. 106f.). The pradeśa theory in turn led to the differentiation of "the standpoint of ksetra or space from the standpoint of dravya or substance" (ib., p. 100) and to the elevation of $\bar{a} k \bar{a} s a$ to an independent substance, as in other systems (ib., p. 106f.). "Heretics" questioned the astikāya theory (ib., p. 103f.). ${ }^{206}$ But it is precisely this theory which must have contributed to the subsequent avoidance of a karman reductionism in the manner of the Andhakas and the Advaitins and hence to subsequent discussions of problems of multiple causalities in the Jaina tradition, echoing similar debates in Brāhmaṇical and Buddhist circles at the time, analysed by Halbfass (1991/1992).

The most influential and essentially unsurpassed solution of the problem of multiple causalities in Jaina philosophy was formulated by Ācārya Siddhasenadivākara, the famous Jaina logician who lived in the fifth and sixth century C.E. He was claimed by both Digambaras and Śvetāmbaras as one of theirs, but linked to

\footnotetext{
203 siddhe nam bhamte ! kim poggalī? poggale? goyamā! no poggalī, poggale $\|502\|$

se kenatthenam bhamte! evam vuccai -siddhe no poggalī, poggale?

goyamā ! jìvam paducca | se tenațhenam goyamā ! evam vuccai - siddhe no poggali, poggale $\| \mathbf{5 0 3 \|}$ ( $\mathrm{Viy}_{3} 8.10 .502 \mathrm{f}$.).
}

204 On this passage see Schubring $(1935 / 2000$, § 67, p. 147) (poggali = bearer of senses), and Deleu (1970, p. 158) ("The soul (jīva) is poggalī scil. Possesses atoms of matter, namely in the senses, as well as poggala, i.e. individual. This is also true for every being in the samsāra, but not for the Siddha who is only poggala"). See also Schubring (1935/2000, § 59, p. 132) ("poggala, the word for atom, is applied in its basic meaning as a 'concrete body' in Viy. 176a, whereas in 240a it means the part of an individual"), and Deleu (1970, p. 116) ("atom", "object").

205 Sikdar (1964, p. 561) notes that “"Lp]oggala' sometimes stands as synonym for soul”; as in Viy ${ }_{1}$ 20.2.2 (775b) $=$ Viy $_{3} 20.2 .17$, where poggala is listed as one of twenty synonyms (including $\bar{a} y \bar{a}$ ) for the word jiv $v a$, but "in the sense of body" according to Deleu (1970, p. 253). On the Buddhist Puggalavādins conception of personal entity (puggala), see also KV I.1.198 and McDermott (1975, p. 424f.).

206 See Ohira 1994: 104f. on the Kālodāyī episodes in Viy. 7.10, 13.4, 18.7. 
the Yāpanīya tradition by Upadhye (1974/1983, p. 200) because of his "differences with the known doctrines of the Digambaras and Śvetāmbaras". In his Prakrit Sammmatitarkaprakaraṇa (STP) III.53, Siddhasenadivākara distinguished five theories of causation (kāraṇa) in Indian philosophy: time (kāla), nature (sahāva), destiny (niya $)$, (unknown) actions of the past (puvva-kaya), and human effort (purisa). ${ }^{207} \mathrm{He}$ argued that individually, taken in isolation (egamta), they are all one-sided and hence false, but if considered together (samāsa), from a perspective of synthesis, they are all true. ${ }^{208}$ According to this interpretation, not the content of a proposition, but the orienting point of view is decisive for its relative "truth-value". This is one of the first explicit versions of the philosophy of anekanta-vāda, or nonone-sidedness, which is nowadays seen as a trademark of Jaina philosophy. According to Siddhasenadivākara (STP III.46-49), ${ }^{209}$ there are as many heresies (para-samaya) as there are standpoints (naya), because all one-sided standpoints necessarily emphasise contradiction (pari-virodhana). The Jaina perspective, by contrast, emphasises synthesis (samanvaya). By transcending differences and disputes based on one-sided perspectives through its concept of anekānta-vāda Jainism (jina-vacana) encompasses all heresies:

207 These are well-known and mostly pre- or non-Jaina theories, starting with ŚvUp 1.1.2, have been formally incorporated in Jaina philosophy in form of the so-called "363 account". See Schrader (1902, pp. 2-4, 17-57), Barua (1921/1970, p. 198), Folkert (1993, p. 233f., 274f., 327-329) (Translation of Haribhadra's Nandīvrtti).

208 kālo sahāva niyā̃ puvvakayam purisa kāraṇegaṃtā ।

micchattam te cevā (va) samāsao homti sammattam \| 53\|

$\left(\mathrm{STP}_{3}\right.$ III.53)

In his commentary, Abhayadeva gave the following Sanskrit gloss:

kāla-svabhāva-niyati-pūrvakrta-puruṣakāraṇarūpā ekāntāh sarve 'pi ekakā

mithyātvam ta eva samuditāh parasparā'jahaddhattayah samyaktva-rūpatām. pratipadyante iti tātparyārthah I (TBV III.53)

Following the Sanskrit commentary, the Gujarātī editors and commentators Sañghavī and Dośī 1932/ 1952: 171 inserted the word "adṛsta" after "pūrvak.ta" in their Gujarātī translation of Abhayadevasūr's Sanskrit rendition and give the following equivalent terms for the five causes in their Gujarātī commentary: kāla, svabhāva, nivrtti, karma, purușa. A. S. Gopani 1939/2000: 127 offered the following English rendition of the gāthä:

Kāla (Time), Svabhāva (Nature), Niyati (Destiny), Pūrvakrta Adrsțta (Unknown actions of the past) and Purusāartha (effort) - all these five taken singly are false because they touch only one point. They all are true if they are made use of with reference to each other $\left(\mathrm{STP}_{3}\right)$

The role of personal effort (purușärtha) is decisive from the Jaina point of view. See footnote 41 . Sanghavī's and Dośî̀'s 1929: 710, n. 5 note to their edition of the original text with the commentary TBV III.53 point to several other texts that address the problem of different causalities, not all of them Jaina texts, amongst them Haribhadra's eighth century Śāstravārtāsamuccaya (ŚVS) II.164-174 = II.52-62, II.191-193 = II.79-81 and earlier verses.

209 Interpreted by Abhayadevasūri and further by Sañghvī and Doŝî (1939/2000, pp. 121-124). 
[Let there be] prosperity to Jina's words that are made of an amassment of false views, that are conducive to immortality, that are venerable, and lead to the salvific happiness (STP III.69, ${ }^{210}$ Translated by Balcerowicz 2003, p. 42). ${ }^{211}$

Elaborating on this perspective, the previously mentioned Śvetāmbara Ācārya Abhayadevasūri in his twelfth century commentary Tattvabodhavidhāyinī (TBV) pp. 710-717 established "his own Kāraṇa-Samavāya-Vāda". ${ }^{212}$ The terms samavāya, "combination", and samavāya-buddhi, "understanding of combination", are used by Abhayadevasūri (TBV 1 , pp. 106-110, 156f., 700-4) in their literal sense, not in the technical Vaiśeșika sense of "inseparable concomitance", "inherent-" or "material cause", or "inherent relationship" between substance and quality or whole and part, ${ }^{213}$ to which they obviously allude. Sanghavī and Doś1 (1932/1952, p. 312 , n. $1 / / 1939 / 2000$, p. 126 , n. 1) use the synonym samanvaya, "synthesis", ${ }^{214}$ and refer in a footnote $\left(\mathrm{TBV}_{1}\right.$, p. 710, n. 5) to the Sanskrit Śvetāśvatara Upanișad v. 2, a late text of the Yajurveda tradition ${ }^{215}$ addressing the question of the cause of Brahma (brahma-kāraṇa), ${ }^{216}$ as the likely model for Siddhasenadivākara's Prakrit verse ( $g \bar{a} t h \bar{a})$. Here, the term samyoga, "junction, union" (MW 1181) is used in a thematically similar context; ${ }^{217}$ but rather than "actions of the past" (pūrva-kṛta-kāraṇa) listed by Siddhasenadivākara, "chance" (yadrcchā), is given prominence amongst the causal factors: ${ }^{218}$

Should we regard it [the cause of Brahman] as time, as inherent nature, as necessity, as chance, as the elements, as the source of birth, or as the Person?

210 baddạ̣ micchā-damsaṇa-samūha-maiyassa amayasārassa |
jiṇa-vayaṇassa bhagavao saṃvigga-suhāhi-gammassa ||STP III.69||

An alternative rendition into English is offered by A.S. Gopani in $\mathrm{STP}_{3}$, p. 136:

Be good to Jainism which is the repository of all heresies and which is the nectar or nectars and which is easily understood by those desirous of liberation.

211 Mahāprajña (ViyBh 8.1.1) concludes his own overview of the theoretical debate with the summary statement that the two doctrines of karmic causality (purușārtha-vāda) and natural causality (svabhāva$v \bar{a} d a)$ are not opposites in Jaina philosophy but integrated through the standpoint of non-one-sidedness (anekānta-vāda). This doctrine, one may add, was not yet explicitly formulated in the Prakrit canon, but only in the philosophical treatises of the medieval period.

212 These are the words of the translators and commentators Sanghavī and Dośi (1932/1952, p. 171 // 1939/2000, p. 127). Cf. the Vaiśeșika concept of samavāya-kāraṇa, inherent cause, as one of the sāmagrī, or totality of causal conditions (Potter 1977/2004, pp. 54f., 60).

213 See Monier-Williams (1899/1986, p. 1157f.), Oberhammer, et al. (2006, pp. 227-229).

214 From the root sam-anv- $\sqrt{ } i$, "to go together after, follow, MW.; to infer or ensue as a consequence": "regular succession or order, connected sequence or consequence, conjunction, mutual or immediate connection" (Monier-Williams 1899/1986, p. 1155). In contrast to samavāya, samanvaya implies the concept of an ordered sequence; which tallies well with the Jaina doctrine of standpoints.

215 “composed probably in the last few centuries BCE" (Olivelle 1996/2008, p. xxxvii).

216 kālah svabhāvo niyatir yadrcchā, bhūtāni yonih puruṣa iti cintyam |

samyoga eșām na tv ātmabhāvāt ātmā py anīsah sukha-duhkhahetoh \|

$\left(S_{\mathrm{vUp}}\right.$ 1.2)

217 The term also appears in STP III.60! (TBV 1 III.60, p. 727). On the technical term samyoga, "connection", as an attribute of an object which serves as an argument in a syllogism in the Vaiśeșikasūtras, see Oberhammer, et al. (2006, p. 202f.).

218 The position of the jaicchāvāis is mentioned in the Namdī. 
Or is it a combination of these? But that can't be, because there is the self (ätman). Even the self is not in control, because it is itself subject to pleasure and pain (ŚvUp 2 1.2, Translated by Olivelle 1996/2008, p. 253). ${ }^{219}$

\section{Concluding Observations: The Ascetic Body and its Remains}

The idea of the transmission of ascetically acquired energy from one individual to another is well established in all Indic religious traditions. ${ }^{220}$ Most Jains feel invigorated when they touch the feet of their gurus while receiving their blessings. The same applies to their physical remains. The question how this transfer of energy works is rarely posed both in the Jain tradition and in the academic literature. The belief in the regenerative powers of relatively durable body parts of animals and humans especially bones is attested across cultures. It is evidently particularly significant in hunting societies (Friedrich 1943: 201f. 216f.) but also in the cattle breading vedic and other societies (Oldenberg 1894/1917: 385f.). In one way or another the manipulation and interpretation of these material objects has therefore played a pivotal role in human history albeit in different degrees. P. Granoff (2008: 60) pointed out that not only in Buddhist contexts but already in the Atharvaveda 4.10.7 "the bones of certain dead individuals had unusual properties and could naturally transform themselves into something else". The idea that bones and other body parts of extraordinary human and divine beings who died a special death either through sacrifice or self-mortification "transform themselves" into other objects of considerable purity and power that appear worthy of veneration (ib. p. 61, 66), for instance pearls, precious metal, conch shells, etc., is also evident in a wide variety of Hindu narrative texts which seem intent on testifying "the continued presence of the god" in his relics (ib. p. 69). The underlying conception seems to be that not human remains as such, which are considered impure, are powerful and hence worthy or worship, but secondary objects that were created by these remains themselves in unexplained ways. Hence there would be two types of relics, in the Buddhist distinction between "dirty" charred bones (asthi) and "jewel-like" relics (dhätu or śarīrāni) remaining after cremation.

Jaina literature generally does not distinguish between two types of relics and speaks generally only about asthis in the few texts which deal with relic worship. ${ }^{221}$ This article has shown that the Jaina theory of transformation offers also conceptual tools for understanding the distinct power of the bodies and body parts of extraordinary ascetics compared to those of ordinary human beings or of divine beings who according to Jaina metaphysics do not possess gross physical bodies.

\footnotetext{
${ }^{219}$ I am grateful to P. S. Jaini, who was the first to point me to this passage.

${ }^{220}$ One textual example for this method of transmission of power from a Hindu context will suffice: "the person who touches his limbs with the garland that was taken off by Kṛnna is free from all disease and all sin" (Haribhaktivilāsa 219 cited by Granoff 2008: 69).

221 The word sakahā "thigh" (thigh bone) used for the mythical relics of the Jinas (there are no relics of the Jinas and hence no corresponding relic cult only a relic cult of subsequent monks and nuns) is worth while investigating further from a comparative perspective. Cf. Friedrich (1943).
} 
Explanations offered by Jaina mendicants for the transmission and absorption of such powers vary between the indistinct allusion to the miraculous "powers of belief",222 and claims of "physical transformations" being effected through contact "between pudgalas". ${ }^{223}$ For the majority of Jainas, the theology of sacred matter is however not an issue of great concern, despite the fact that the fetishism of sacred objects plays a role in Jaina religious life as well, albeit merely a subordinate one. The prime aim of ascetic practice, they maintain, is the purification of the soul, not the empowerment of the body; an aim which is explicitly associated with Hindu asceticism rather than with Jainism. ${ }^{224}$ It is conceded, however, that the acquisition of superhuman mental and physical power is an inevitable side-effect of the practice of asceticism. The use of these powers needs to be renounced. ${ }^{225}$

222 The Digambara munis Amodhakīrti and Amarakīrti after going through most of the options of interpretation including the niksepa of dravyamargala finally invoked interpretations why relics of ascetics have no effect on the living: because (1) "it is nowhere written", (2) the "bones of monks and householders are the same", (3) the "relics of monks are only touched not eaten (unlike pills)", (4) "there may or may not be a relic under a nisidhi", (5) "the body can be looked at from two perspectives like a steel vessel containing ghee which can with equal right be labelled 'steel vessel' or 'ghee vessel'" (personal communication Mumbaî 1.1.2012).

223 While not touching on the question of relics and reiterating the standard academic narrative of the suspected presence of metaphysical entities in sacred objects J. Laidlaw (1995: 271) argued that the body of the Jaina ascetic is perceived as an icon of perfection in a similar way as Jina statues in the templeand equally worthy of worship:

Reverence for Jain renouncers thus uses the same modes as worship of Jina idols: similar gestures and texts the same emphasis on visual interaction the same concern with bodily contact. Like the Jina idol the renouncer then is a presence though attenuated and partial of the perfect soul. But if idols and renouncers are both in their ways icons of the living Jina the relations between these two icons are curiously complex (ib.).

224 A classical early Hindu text on the acquisition of superhuman power through ascetic restraint is Patañjali's Yogasūtra (YS):

tato'ṇimādiprādurbhāvahkayasampattaddharmānabhighātaśca \|46\| rūpa-lāvanya-bala-vajrasaṃhananatvāni kāyasampat \|47||

Thereform spring up (three perfections i.e.) minute etc. excellence of the body and nondestruction of the merits of it (46).

The excellence of the body consists of colour loveless strength and adamantine density (YS

3.46f. rendered into English by J. R. Ballantyne and GovindSastry Deva).

On the influence of the YS and of Śaivism and Tantrism on Hemacandra'sYogaśāstra (YŚ) see Qvarnström 2003: 7 n. 4; 97 n. 2. See also White (1996) and Jacobsen (2012)

225 This sentiment seems to be particularly strong in the orthodox Sthānakavāsī traditions. Considering the question addressed in this article Ācārya Śubhacandra of the Jaymalgacch for instance categorically stated: "Meditation affects only the soul not the body. The body is not purifiedby meditation only by medicine"; "There is no end to the desires of the body and there are no specific physical powers produced by religious practice"; "The only power that is relevant is the strength of the self or atam-bal" (personal communication Jodhpur 2.1.2010). A lay-women assisting Sādhvī Candrakamitā of the Jñāngacch asserted: "Jainism is not Yoga!" The sādhvi agreed and while agreeing that outside matter such as food can be helpful on a material level added that Jaina practice is not oriented toward the body but primarily aims at strengthening the soul to create àtma-śakti, power of the self (personal communication Jodhpur 3.1.2010 ). 


\section{References}

\section{Primary Sources}

ĀvB Visesāvassayabhāsa (Viśeșāvaśyakabhāṣya) by Jinabhadra. 6th-7th century. Ed. Dalsukh Mālvaṇiyā: Jinabhadragaṇi-

Kṣamāśramaṇaviracitam Viśeșāvaśyakabhāṣyaṃ Svopajñavṛttisahitam.

Amadāvād: Lālbhāī Dalpatbhāī Bhāratīya Saṃskṛti Vidyāmandir, 1966/1993.

ĀvC Āvassayacunni (Āvaśyakacūrni) by Jinadāsa Gani Mahattara. 7th century. In: Śrīmadāvaśyakasūtram. 2 Vols. Prakāśikā: Rsabhadeva Keśarīmal. Ratlām: Rsabhadeva Keśarīmala Samsthā, 1928-1929.

$\bar{A} v N_{1}$ Āvassayanijjutti (Āvaśyakaniryukti) by Bhadrabāhu. In: ŚrīmadĀcāryavarya-Bhadrabāhu-Tata-Niryuktiyutam Pūrvadhar-Ācārya-VihitaBhāsya-Bhūsitam Śrīmad-Bhavaviraha-Haribhadrasūri-Sūtrita-VrttyAlañkrtam Śīmad-Āvaśyakasūtram (Prathamo \& Pūrva Vibhāgah). Prakāśakah Javherī Cunīlāla Pannālāla-Datta-Kiñcid-Adhikārgha-DravyaSāhāyena Sāha-Veṇīcanda-Sūracanda Asyaikạ̣ Kāryavāhakaḥ.Idaṃ Pustakaṃ Mumbayyāṃ Nirṇayasāgaramudraṇāspade Kolabhāṭavīthyāṃ 23 Tame Gṛhe Rāmacandra Yesū Śẹ̣agedvārā Mudrayitvā Prakāśitam, 1916 (Āgamodayasamitisiddhāntasamgrahe Añkạ̣ 1).

$\overline{\mathrm{A}} \mathrm{NN}_{2}$ Āvassayanijjutti (Āvaśyakaniryukti) by Bhadrabāhu. Ed. Saman̄ī Kusumaprajñā (Sampādikā): Āvaśyaka Niryukti. Khạ̣̣a 1. Lādnūm: Jaina Viśva Bhāratī Samsthāna, 2001.

ĀvND Āvaśyakka Niryukti Dīpikā by Mānikyaśekhara. 15th century.

ĀvS Āvassayasutta (Āvaśyakasūtra). In: Dasaveyāliyasuttaṃ, Uttarajjhayan̄āiṃ, Āvassayasuttaṃ. Ed. Muni Punyavijaya \& Amṛtalāl Mohanlāl Bhojak (Sampādakau) 331-358. Jaina-Āgama-Granthamālā Granthāṅka 15. Bambaī: Mahāvīra Jaina Vidyālaya, 1977.

$\overline{\mathrm{A}} v \mathrm{~V}$ Āvaśyakavrtti by Haribhadra. In $\overline{\mathrm{A}} \mathrm{NN}_{1}$.

BKB Bṛhatkalpabhāṣya. By Sañghadāsa. In: BKS.

BKS Bṛhatkalpasūtram. With Niryukti of Bhadrabāhu, Bhāsya of Sañghadāsa, Tikā of Malayagiri Completed by Kṣemakīrti. Ed. Muni Caturvijaya \& Muni Punyavijaya. Bhāvnagar: Ātmā̄nand Jain Sabhā, 1933-1938/2002 (Ātmānanda-Jaina-Grantharatnamālā-Ratnam 82).

DVS Dasaveyāliya (Daśavaikālika Sūtra) by Ārya Sayyaṃbhava. In: The Dasaveyāliya Sutta. Ed. Ernst Leumann. And Translated, with Introduction and Notes, by Walther Schubring. Ahmedabad: The Managers of the Sheth Anandji Kalianji, 1932 (Reprinted: Kleine Schriften. Hg. Klaus Bruhn, 109-248. Wiesbaden: Franz Steiner, 1977).

$\mathrm{KG}_{1} \quad$ Karmagrantha. Devendrasūriviracita-svopajña-tikāyukta. Vol. I-II. Bhāvnagar: Jaina-dharma-prasāraka-sabhā, VS 1966-1968 [1910-1912].

$\mathrm{KG}_{2}$ Śrīmad Devendrasūri Viracita Karmavipāka Nāmaka Karmagrantha. Mūla, Gāthārtha, Viśeșārtha, Vivecana evaṃ Ṭippaṇa tathā Pariśișta Yukta. In: Jaina Karmaśāstra kā Sarvānga Vivecana. Vyākhyākara: Marudhar Kesarī Pravartaka Muni Śrī Miśrīmal. Dvitīya Āvṛtti. JodhpurByāvar: Marudharakesarī Sāhitya Prakāśan Samiti, 1974/1980.

$\mathrm{KV}_{1}$ Kathāvatthu. Ed. Arnold C. Taylor. Vol. I. London: Pali Text Society, 1894.

$\mathrm{KV}_{2}$ Points of Controversy, or, Subjects of Discourse. Being a Translation of the Kathā-vatthu from the Abhidhamma-pitaka by Shwe Zan Aung and Caroline Augusta Foley Rhys Davids. London: Pali Text Society, 1915.

KVA The Debates Commentary (Kathāvatthuppakarañā-Ațhakathā). Translated into English by Bimala Churn Law. London: Pali Text Society, 1940.

LTS Amrtacandrasūrikrtah Laghutattvasphota. Edited and Translated by Padmanabh S. Jaini. L.D. Series 62. Ahmedabad: L. D. Institute, 1978.

$\mathrm{NS}_{1} \quad$ Namdisuttam \& Aṇuogaddārāim . Sampādakāh: Muni Punyavijaya, Paṇdit Dalsukh Mālvaniyā \& Pandit Amrtalāl Mohanalāl Bhojak, 1-55. JainaĀgama-Granthamālā Granthānika 1. Bambaī: Mahāvīra Jaina Vidyālaya, 1968.

$\mathrm{NS}_{2} \quad$ Namị̄ (Nandīsūtra). In: Navasuttānini. Ditīya Saṃskaraṇa. Vācanā 
Pramukha: Ācārya Tulsī. Sampādaka: Ācārya Mahāprajña, 245-288.

Lādnūm: Jaina Viśva Bhāratī, 1985/2000.

$\mathrm{NS}_{3} \quad$ Naṃdī (Nandīsūtra). Sampādit/Vivecit. Vācanā Pramukha: Gaṇadhipati

Tulsī. Sampādaka: Ācārya Mahāprajña. Lāẹnūṃ: Jain Viśva Bhāratī

Saṃsthāna, 1997.

$\mathrm{NS}_{4} \quad$ Sacitra Śrī Nandīsūtra. Hindī-Angrezī Bhāsānuvāda Sahita. Pradhāna

Sampādaka: Upapravartaka Amar Muni. Sampādaka: Śrīcand Surānā

"Saras". Dillī: Padma Prakāśana, 1998.

NSBh Nandīsūtrabhāsya [Ṭ̄īkē] by Ācārya Malayagiri. In: Weber 1888 II.1: 672-691.

$\mathrm{P}_{1} \quad$ Pannavanāa (Prajñāpanāsūtra) by Ārya Śyāma. In: Pannavanāsuttam.

Jaina-Āgama-Series No. 9, Part 1-2. Ed. Muni Punyavijaya,

Dalsukh Mālvaniyāa, Amritlāl Mohanlāl Bhojak. Bombay: Mahāvīra

Jaina Vidyālaya, 1969, 1971.

$\mathrm{P}_{2} \quad$ Pannnavaṇā (Prajñāpanāsūtra) by Ārya Śyāma. In: Uvañgasuttāni 2.

Vācanā Pramukha: Ācārya Tulsī. Sampādaka: Yuvācārya Mahāprajña, 1-356. Lāụnūṃ: Jaina Viśva Bhāratī, 2002.

Panhā ${ }_{1}$ Panhāvāgaranāiẹ̀ (Praśnavyākaranānisūtra). In: Angasuttāni 3. Vācanā

Pramukha: Ācārya Tulsī. Sampādaka: Yuvācārya Mahāprajña, 635-713.

Dvitīya Saṃskaraṇa. Lāẹnūm: Jaina Viśva Bhāratī Samsthāna, 1974/1992.

Panhā $_{2}$ Panhā̄vāgaranāim (Praśnavyākaranānisūtra). In: Sacitra

Praśnavyākarana Sūtra. Mūla Pātha: Hindī-Aringrezī Bhāvānuvāda,

Vivecana tathā Rañgīna Citroṃ Sahita. Prathama Sampādaka: Pravartaka

Amar Muni. Saha-Sampādaka: Varuṇ Muni "Amar Śișya” \& Sanjay

Surānā. Añgrezī Anuvāda: Rājkumār Jain. Dillī: Padma Prakāśana, 2008.

PS Pravacanasāroddhāra by Nemicandra (11th century). 110 Dvāroṃ kā Mūla, Gāthārtha evaṃ Āgamajña Śrī Siddhasenasūri Racit Tattvavikāśinī Tị̂ā

kā Hindī Vivecana. Anuvādikā: Sādhvī Hemaprabhā. Sampādaka:

Mahopādhyāya Vinaysāgar. Jaypur: Prākrt Bhāratī Akādamī, 1999.

$\mathrm{SaSi}_{1} \quad$ Sarvārthasiddhi. Śrīmad Ācārya Pūjyapāda Viracit. Śrīmad Ācārya

Grddhapiccha Pranīta Tattvārthasūtravrtti Sahita. Sampādana-Anuvāda:

Siddhāntācārya Phūlcand Śāstrī. Twelfth Edition. Naī Dillī: Bharatīya Jñānpịth, 2003.

$\mathrm{SaSi}_{2}$ Sarvārthasiddhi by Pūjyapāda. In: S.A. Jain 1960/1992.

$\mathrm{SaSi}_{3}$ Sarvārthasiddhi by Pūjyapāda. In: TS.

SS Achärya Kundakunda's Samayasāra. Edited and Translated by A. Chakravarti. Third Edition. New Delhi: Bharatiya Jnanpith, 1950/1989.

$\mathrm{STP}_{1}$ Sammatitarkaprakaranam. Ācārya-Śrī-Siddhasena-Divākara-Pran̄ìntạ. Abhayadevasūri-nirmitayā Tattva-bodha-vidhāyinyā Vyākhyayā Vibhūṣitam. I-II. Pāthāntara-Tippanyādibhih Pariṣkrtya Samśodhitam: Sukhlāl Sanghvī \& Becardās Dośî. Amadāvād: Gujarāt Vidyāpīth, Gujarāta-purā-tattva-mandira-granthāvalī, Samvvat 1980-1985 [1924-1929] (Reprint: Amadāvād: Āśāpūraṇ Pārśvanāth Jain Jñānabhaṇdār, 2011).

$\mathrm{STP}_{2}$ Sanmati Prakaraṇa. Ācārya Siddhasena Divākara Praṇît. Prastāvanā ane Vivecana sāthe Anuvādaka: Sukhlāl Sañghvī \& Becardās Dośí. Amadāvād: Gujarāt Vidyāpịthh, Puñjābhāī Jain Granthamālā 6, 1932/1952.

$\mathrm{STP}_{3}$ Siddhasena Divākara's Sanmati Tarka. With a Critical Introduction and an Original Commentary by Pandita Sukhlalji Sanghavi and Pandita Bechardasji Doshi. Translated from Gujarati: A.B. Athavle (Introduction) \& A. S. Gopani (Text \& Commentary). Amadāvād: Gujarāt Vidyāpīth, 1939 (Cited after the Reprint: Ahmedabad: L.D. Institute, Sukhlalji Series 5, 2000).

$\mathrm{STP}_{4}$ Saṃmatitarkaprakaranam. Siddhadenadivākarasūri Viracita. Tarkapañcānana-vādimukhya-Abhayadevasūri Viracitā Tattvabodhavidhāyiñ̄ Vrttti. Ācārya Jayasundarasūri Kṛta Hindī Vivecana. Kalikunḍa Tīrtha, Gholkā: Divyadarśana Ṭasț, Vikram Samvat 2066 (2010).

ŚVS Ācārya Haribhadrasūri's Śāstravārtāsamuccaya. With Hindi Translation, Notes and Introduction. Translated by K.K. Dixit. Second Edition. Ahmedabad: L.D. Institute, L.D. Series 128 (22), 1969/2002.

ŚvUp ${ }_{1}$ Śvetāśvatara Upanișad. TITUS. On the Basis of the Edition by Thomas Oberlies. "Die Śvetāśvatara Upanișad. Einleitung, Edition und 
Übersetzung.” Wiener Zeitschrift für die Kunde Südasiens 32 (1988) 35-62, 39 (1995) 61-102, 40 (1996) 123-160, 42 (1998) 77-138.

http://titus.uni-frankfurt.de/texte/etcs/ind/aind/ved/yvs/upanisad/svetup/svetu.htm and http://fiindolo.sub.uni-goettingen.de/gretil/1_sanskr/1_veda/4_upa/svetu_pu.htm

ŚvUp $p_{2}$ Śvetāśsvatara Upanișad. In: Upanișads. A New Translation by Patrick Olivelle, 252-265. Oxford: Oxford University Press, 1996.

Sūy Sūyagada (Sūtrakrtāingasūtra). In: Jaina Sūtras II. Translated by Hermann Jacobi. Sacred Books of the East Vol. 45. Ed. Max Müller, 233-435. Oxford: Clarendon Press, 1895.

$\mathrm{TBV}_{1}$ Tattvabodhavidhāyin̄̄ by Abhayadevasūri. In: $\mathrm{STP}_{1}$

$\mathrm{TBV}_{2}$ Tattvabodhavidhāyin̄̄ by Abhayadevasūri. In: $\mathrm{STP}_{4}$

Ṭhāna ${ }_{1}$ Thāna (Sthānāngasūtra). Mūla-Pātha, Samskṛta Chāyā, Hindī Anuvāda tathā Ṭippaṇa. Vācanā Pramukha: Ācārya Tulsī. Sampādaka Vivecaka: Muni Nathmal. Lāḍnūim: Jaina Viśva Bhāratī, 1976.

Ṭhāṇa 2 Sacitra Śrī Sthānāinga Sūtra. Mūla-Pāṭha, Hindī-Añgrezī Anuvāda, Vivecana tathā Ranigina Citroṃ Sahita. Pradhāna Sampādaka: Pravartaka Amar Muni. Saha-Sampādaka: Tarụ Muni \& Śrīcand Surānā 'Saras'. Añgrezī Anuvādaka: Surendra Botharā. Dillī: Padma Prakāśana, 2004.

TJV Tattvajñānavikāśinī by Siddhasenasūri (1185 C.E.). In: PS.

$\mathrm{TP}_{1}$ Tiloyapaṇnattī by Ācārya Yativṛṣabha. 5th-7th century. Khaṇụa I-III. Purovāk: Pannālāla Jaina. Anuvādikā: Āryikā Viśuddhamati. Tṛtīya

Saṃskaraṇa. Deharā-Tijārā: Candraprabha Digambara Jaina Atiśaya Kșetra, 1984/1997.

$\mathrm{TP}_{2}$ Tiloyapaṇnattī by Ācārya Yatiṿșabha. 5th-7th century Translated by Laxmi Chandra Jain. With the Collaboration of Prabha Jain. In: The Exact Sciences in the Karma Antiquity. Volume 1. Mathematical Sciences of the Tiloyapannattī (Information of the Three Universes). Jabalpur: Brāhmī Sundarī Prasthāśram Samiti, 2003.

TRV Tattvārtharājavārtika by Akalañka. In: ViyBh.

$\mathrm{TS}_{1}$ Tattvārthasūtra by Umāsvāti. In: That Which is. Tattvārthasūtra of Umāsvāti / Umāsvāmī with the Combined Commentaries of Umāsvāti/ Umāsvāmī, Pūjyapāda and Siddhasenagaṇi, Translated with an Introduction by Nathmal Tatia. San Francisco: Harper Collins, 1994.

$\mathrm{TS}_{2} \quad$ Tattvārthasūtra by Umāsvāmī. In: $\mathrm{SaSi}_{12}$

TSB Tattvārthasūtrādhigamabhāṣyavrtti by Siddhasenagaṇin (c. 9th century).

TŚPC $_{1}$ Triṣaș̣iśalākāpuruṣacaritramahākāvyam. Kalikālasarvajña Hemacandrācāryaviracitạ̣. 1 Parvāṇ̄̄, Sampādaka: Muni Caraṇavijaya. 2-3-4 Parvāṇ̄̄, Sampādaka: Muni Punyavijaya. 5-6-7 Parvāṇī \& 8-9 Parvāṇi, Sampādakaụ Ramaṇīkavijaya Gaṇi \& Vijayaśīlacandrasūri. Ahmadābād: Kalikālasarvajña Śrī Hemacandrācārya Navama Janmaśatābdī Smṛti Śikṣāṇa Saṃskāranidhi, 1990, 2001, 2006.

$\mathrm{TŚ}_{2} \mathrm{C}_{2}$ Triṣaștiśalākāpuruṣacaritramahākāvyam. Śr̄̄mad Hemacandrasūriśvaraviracitạ̣. Daśam Parva. Samśodhaka-Sampādaka: Subodhacandra Nānālāla Śāh. Mumbāi: Śrīmatī Gañgābhāī Jain Ceritabal Trast, 1977.

$\mathrm{TŚ}^{\mathrm{P} C} \mathrm{C}_{3}$ Trișaștiśalākāpuruṣacaritra by Hemacandra. Translated by Helen M. Johnson as The Lives of Sixty-three Illustrious Persons (6 Vols.). Baroda: Oriental Institute, 1931-1962.

TV Tattvārthavārtika by Akalañka (8th century). 2 Vols. Hindīsārasahitam. Sampādana-Anuvāda: Mahendrakumār Jain. Caṭhā Saṃskaraṇa. Mūrtidevī Jaina Granthamālā, Saṃskṛt Granthāṃkara 20. Naȳ̄ Dillī: Bhāratīya Jñānapīṭha, 2001.

Utt $_{1} \quad$ Uttarajjhayaṇa (Uttarādhyayanasūtra). In: Jaina Sūtras II. Translated by Hermann Jacobi. Sacred Books of the East Vol. 45. Ed. Max Müller, 1-232. Oxford: Clarendon Press, 1895.

Utt $_{2}$ Uttarajjhayaṇāni (Mūlapātha, Saṃkșipta Chāyā, Hindī Anuvāda, Tulanātmaka Ṭippaṇa). Vācanā-Pramukha: Ācārya Tulsī. Sampādaka \& Vivecaka: Ācārya Mahāprajña. Tṛtīya Saṃskarạn. Lāḍnūṃ: Jaina Viśva Bhāratī, 1967/2000.

UttN Uttarajjhāyananijjjutti. In: Bollée, W. B. (1995). The Nijjuttis on the Seniors of the Śvetâmbara Siddhânta. Āyāranga, Dasaveyāliya, Uttarajjhāyā and Sūyagaḍa. Text and Selective Glossary (pp. 75-117). Beiträge zur Südasienforschung Südasien-Institut Heidelberg 169. Stuttgart: Franz Steiner Verlag.

$\mathrm{Uv}_{1}$ Ovāiyam (Aupapātikasūtra). In: Uvạ̣gasuttāṇi. 4.1. Vācanā Pramukha: 
Gaṇādhipati Tulsī. Sampādaka: Ācārya Mahāprajña, 1-77. Lāḍnūṃ: Jaina Viśva Bhāratī, 2002.

$\mathrm{Uv}_{2} \quad$ Uvavāiya (Aupapātikasūtra). In: Sacitra Aupapātika Sūtra (Caturdaśa Pūrvadhara Sthavira Praṇīta Prathama Upāniga). Mūla-Pāṭha, HindīAñgrezī Anuvāda, Vivecana Tathā Rañgīna Citroṃ Sahita. Prathama Sampādaka: Uttara Bhāratīya Pravartaka Bhạ̣dārī Padmacadra Suśișya Upapravartaka Amar Muni. Saha-Sampādaka: Śrīcand Surānā 'Saras'. Añgrezī Anuvādaka: Surendra Botharā. Dillī: Padma Prakāśana, 2003.

ViĀvB Visesāvassayabhāsa (Viśeșāvaśyakabhāsya) by Jinabhadra. 6th-7th century. Ed. Dalsukh Mālvaniyā: Śn̄-Jinabhadragaṇi-

Kṣamāśramaṇa-Viracitạ̣ Viśeșāvaśyakabhāṣyam Svopajñavṛttisahitam. Amadāvād: Lālbhāī Dalpatbhāī Bhāratīya Sṃskṛti Vidyāmandir, 1966/1993.

Viy $_{1}$ Viyāhapannatti (Bhagavā̄). The Fifth Anga of the Jaina Canon. Introduction, Critical Analysis, Commentary \& Indexes by Jozef Deleu. Brugge: Rijksuniversiteit de Gent, 1970.

$\mathrm{Viy}_{2}$ Viyāhapaṇnattisuttaṃ. Bhāga 1-2. Sampādaka: Becardās Jīvarāj Dośi. Sahāyaka: Amrtalāl Mohanlāl Bhojak. Jaina-Āgama-

Granthamālā 4, 1-2. Bambaī: Śrī Mahāvīra Jaina Vidyālaya, 1978.

$\mathrm{Viy}_{3}$ Bhagavā̄. Viāhapaṇnattī. In: Añgasuttāṇi 2. Vācanā Pramukha: Ācārya Tuls̄i. Sampādaka: Yuvācārya Mahāprajña. Lāẹnūṃ: Jaina Viśva Bhāratī Samsthāna, 1992.

$\mathrm{Viy}_{4}$ Bhagavaī. Viāhapaṇnattī. Khạ̣ḍa 1-4 (Śataka 1-16). Mūla-Pāṭha, Saṃskṛta Chāyā, Hindī Anuvāda, Bhāṣya Tathā Abhayadevasūri-Kṛta Vṛtti Evaṃ Pariśiș̣ta-Śabdānukrama Ādi Sahit. Vācanā-Pramukha: Ācārya Tulsī. Saṃpādaka/Bhāṣyakāra: Ācārya Mahāprajña. Lāụnūṃ: Jaina Viśva Bhāratīi, 1994, 2000, 2005, 2007.

Viy $_{5}$ Sacitra Bhagavat̄̇ Sūtra (Vyākhyāprajñapti). Mūla-Pātha, HindīAñgrezī Bhāvānuvāda, Vivecana Tathā Citroṃ Sahita. Prathama Sampādaka: Uttara Bhāratīya Pravartaka Amar Muni. Saha-Sampādaka: Śrīcand Surānā 'Saras'. Khaṇụa 1-2 (Śataka 1-8). Angrezī Anuvādaka: Surendra Botharā. Dillī: Padma Prakāśana, 2005-2006.

Viy $_{6}$ Sudharma Svāmō’s Bhagavatī-Sūtra. Śataka 1-11. See Lalwani 1973-1985.

$\mathrm{V}_{7}$ Śrī Bhagavatīsūtram. Tṛtīyom Bhāgaḥ. Jainācārya-JainadharmadivākaraPūjyaśrī-Ghāsīlālajī-Mahārāja Viracitaya Prameyacandrikākhyayā Yyākhyayā Samalan̉kṛtam Hindīgurjarabhāṣā'nuvadasahitam. Niyojakaḥ: Saṃskṛta-Prākṛtajña-Jaināgamaniṣnāta-Priyavyākhyāni-Paṇ̦itamuni-Kanhaiyālālajī-Mahārājah. Prakāśaka: Rāmajībhāī Velajībhāī Vīrīn̄ī \& Kaḍavibāì Vīrān̄ī Ṭast Pradatta-Dravyasāhāyyena Akhil Bhāratāya Śvetāmbara Sthānakavāsī Jainaśāstroddhārasamitipramukhah Śreșṭ̂̄-ŚrīSāntilāla-Mañgaladāsabhāī-Mahodaya. Rājkot: Akhil Bhāratīya Śvetāmbara Sthānakavāsī Jainaśāstroddhārasamiti, 1963.

Viy. $_{8}$ Bhagavaī Viāhapaṇnattī. Prakrit Text in Roman Script, English

Translation of the Text and Ācārya Mahāprajña's Bhāṣya. Vols. 1-4: Śataka

I-II, Vol. 2: Śataka III-VII. Synod Chief (Vācanā Pramukha): Gaṇādhipati

Tulsī. Editor \& Annotator (Bhāṣyakāra): Ācārya Mahāprajña. English

Translator \& Editor: Muni Mahendra Kumār. Ladnun: Jain Vishva Bharati, 2005, 2009.

ViyBh Bhagavaī Viāhapaṇnattī Bhāsya by Ācārya Mahāprajña. In: Viy 4

ViyVṛ Bhagavatīvrtti (Śataka 1-16) by Abhayadevasūri (Pātạn 1072). In Viy

YŚ The Yogaśāstra of Hemacandra. A Twelfth Century Handbook on Śvetāmbara Jainism. Translated with an introduction by O. Qvarnström. Cambridge, Massachusetts: Harvard Oriental Series Vol. 612002.

YS Yoga-Sūtras of Patañjali. With Bhojavṛtti called Rājamārtaṇa (In English translation of J. R. Ballantyne ind Satry Deva). Edited with introduction by A. C. Shastri. Delhi: Parimal Publications 1990.

\section{Secondary Sources}

Acharya, D. (2007). The original Panhhavāyarana/Praśnavyākarana discovered. International Journal of Jaina Studies (Online), 3(6), 1-10. http://www.soas.ac.uk/research/publications/journals/ijjs/file40439.pdf 
Albert, H. (1968/1991). Traktat über kritische Vernunft. Fünfte erweiterte und verbesserte Auflage. Tübingen: J. C. B. Mohr (Paul Siebeck). (English translation Treatise on critical reason, M. V. Rorty, Ed., 1985, Princeton: Princeton University Press.)

Balbir, N. (1990a). Anadhyāya as a Jaina Topic. Wiener Zeitschrift für die Kunde Südasiens und Archiv für indische Philosophie, 34, 49-77.

Balbir, N. (1990b). Scènes d'alchimie dans la littérature jaina. Journal of the European Ayurvedic Society, 1, 149-164.

Balbir, N. (1992). La fascination jaina pour d'alchimie. Journal of the European Ayurvedic Society, 2 , $134-150$.

Balbir, N. (1993). Āvaśyaka-Studien. Introduction Générale et Traductions. Alt- und Neuindische Studien 45, 1. Stuttgart: Franz Steiner Verlag.

Balcerowicz, P. (2003). Some remarks on the Naya method. In P. Balcerowicz (Ed.), Essays in Jaina philosophy and religion (pp. 37-70). Delhi: Motilal Banarsidas.

Basham, A. L. (1951). History and doctrine of the Äjīvikas. London: Luzac.

Bhatt, B. (1983). Stratification in Śatakas 1-20 of the Viyāhapannatti. Indologica Taurinensia, 11, 109-118.

Bhatt, B. (1989). The concept of the self. In Self and consciousness. Indian interpretation (pp. 132-172). Rome: Centre for Indian and Interreligious Studies.

Bollée, W. B. (1999). Adda or the oldest extant dispute between Jains and Heretics (Sūyagaḍa 2, 6) Part Two. Journal of Indian Philosophy, 27, 411-437.

Bollée, W. B. (2006). Adda or the oldest extant dispute between Jains and Heretics (Sūyagada 2, 6) Part One. In P. Flügel (Ed.), Studies in Jaina history and culture: Doctrines and dialogues (pp. 3-32). London: Routledge.

Bourdieu, P. (1980). Le sens pratique. Paris: Éditions de Minuit (Translated from The logic of practice, by R. Nice, Ed., 1980, Cambridge: Polity Press.)

Bronkhorst, J. (2000). Karma and teleology: A problem and its solutions in Indian Philosophy. Studica Philologica Buddhica Monograph Series XV. Tokyo: The International Institute for Buddhist Studies.

Bronkhorst, J. (2003). Jainism's first heretic and the origin of Anekânta-vāda. In O. Qvarnström (Ed.), Jainism and early Buddhism. Essays in honor of Padmanabh S. Jaini (pp. 95-112). Fremont: Asian Humanities Press.

Brown, R. L. (1998). Expected miracles: The unsurprisingly miraculous nature of Buddhist images and relics. In R. H. Davis (Ed.), Images, miracles, and authority in Asian religious traditions. (pp. 2335). Boulder: Westview.

Bruhn, K. (2007). Die Ahimsā in der Ethik des Jaina-Autors Amrtacandra. Berliner Indologische Studien, $18,1-78$.

Chakravarti, A. (1950/1989). Introduction. In A. Chakravarti (Ed., Trans.), Achārya Kundakunda's Samayasāra (3rd ed., pp. 1-100). New Delhi: Bharatiya Jnanpith.

Cort J. E. (1991). Two Ideals of the Śvetāmbar Mūrtipūjak Jain Layman. Journal of Indian Philosophy 19 (1991) 391-420.

Cort, J. E. (2003). Doing for others: Merit transfer and Karma mobility in Jainism. In O. Qvarnström (Ed.), Jainism and early Buddhism. Essays in honor of Padmanabh S. Jaini (pp. 129-150). Fremont: Asian Humanities Press.

Daniel, E. V. (1987). Fluid signs: Being a person the Tamil way (First Paperback Printing). Berkeley: University of California Press.

Deleu, J. (1970). Viyāhapannatti (Bhagavaī). The fifth Anga of the Jaina Canon. Introduction, critical analysis, commentary \& indexes. Brugge: Rijksuniversiteit de Gent.

Deleu, J. (1987-1988). A further inquiry into the nucleus of the Viyāhapannatti. Indologica Taurinensia, 14, 168-179.

Douglas, M. (1966/1970). Purity and danger: An analysis of concepts of pollution and taboo. Harmondsworth: Penguin.

Dumont, L. (1966/1980). Homo Hierarchicus: The caste system and its implications (Complete revised English edition). Chicago: The University of Chicago Press.

Dundas, P. (1998). Becoming Gautama: Mantra and History in Śvetāmbara Jainism. In J. E. Cort (Ed.), Open boundaries: Jain communities and culture in Indian History (pp. 31-52). Albany: SUNY.

Dundas, P. (2006). The later fortunes of Jamāli. In P. Flügel (Ed.), Studies in Jaina history and culture: Disputes and dialogues (pp. 33-60). London: Routledge.

Flügel, P. (2008). Prologue. Gommațasāra (Jīva-Kānda). The summary of the revelation (bio-section). Mathematical sciences in the Karma antiquity (Vol. 1, pp. 1-15). (L. C. Jain with the collaboration of 
P. Jain). Jabalpur: Gulab Rani Karma Science Museum \& Shri Brahmi Sundari Prasthashram. https:// eprints.soas.ac.uk/7437/.

Flügel, P. (2010a). Power and insight in Jaina discourse. In P. Balcerowicz (Ed.), Logic and belief in Indian philosophy (pp. 85-217). Warsaw: Oriental Institute (Warsaw Indological studies, Vol. 3)/ Delhi: Motilal Banarsidas (Complete revised version: http://eprints.soas.ac.uk/8209/).

Flügel, P. (2010b). The Jaina cult of relic stūpas. Numen, 57, 3-4 (Special issue on Relic Worship, Ed. K. Trainor), 389-504.

Flügel, P. (Forthcoming a). Concepts of power in the Jaina tradition. In F. Sin, N. Balbir, \& P. Flügel (Eds.), Kyoto papers in Jaina studies. Papers of the Jaina Panel at the 14th World Sanskrit Conference in Kyoto 2009. Kyoto: Society for Jaina Studies.

Flügel, P. (Forthcoming b). Reflections of the origins of the Jaina doctrine of Karman. In P. Flügel \& O. Qvarnström (Eds.), Jaina Scriptures and Philosophy.

Folkert, K. W. (1993). Scripture and community: Collected essays on the Jains. (J. E. Cort Ed.), Atlanta: Scholars Press.

Frauwallner, E. (1953/1997). History of Indian Philosophy. Vol. I-II. (Translated from the original German by V. M. Bedekar). Delhi: Motilal Banarsidas.

Friedrich, A. (1943). Knochen und Skelett in der Vorstellungswelt Nordasiens. Wiener Beiträge zur Kulturgeschichte und Linguistik 5, 189-247.

Glasenapp, H. v. (1915). Die Lehre vom Karma in der Philosophie der Jainas. Leipzig: Otto Harrassowitz.

Glasenapp, H. v. (1925). Der Jainismus: Eine indische Erlösungsreligion. Berlin: Alf Häger Verlag.

Glasenapp, H. v. (1942). The doctrine of Karman in Jain philosophy. (Translated from the original German by B. Gifford and revised by the author. H. r. Kapadia Ed.) Bombay: Bai Vijibai Jivanlal Panalal Charity Fund.

Glasenapp, H. v. (1999). Jainism: An Indian religion of salvation (S. B. Shroti, Trans.). Delhi: Motilal Banarsidas.

Gonda, J. (1956). Ancient Indian Kingship from the religious point of view. Numen, 3(1), 36-71.

Granoff, P. (1998). Divine delicacies: Monks, images, and miracles in the contest between Jainism and Buddhism. In R. H. Davis (Ed.), Images, miracles, and authority in Asian religious traditions (pp. 55-95). Boulder: Westview Press.

Granoff, P. (2008). Relics, rubies and ritual: Some comments on the distinctiveness of the Buddhist relic cult. Rivista Degli Studi Orientali 81(1-4), 59-72.

Halbfass, W. (1991/1992). Competing causalities: Karma, Vedic rituals, and the natural world. In Tradition and reflection: Explorations in Indian thought (pp. 291-245). Delhi: Sri Satguru Publications.

Halbfass, W. (1992). On being and what there is: Classical Vaiśeșika and the history of Indian Ontology. Albany: State University of New York Press.

Heidegger, M. (1995). Phänomenologie des religiösen Lebens. Gesamtausgabe Band 60. Frankfurt am Main: Vittorio Klostermann. (English translation The phenomenology of religious life, by M. Fritsch \& J. A. Gosetti-Ferencei, Ed., 2004, Bloomington: Indiana University Press.)

Hoernle, A. F. R. (1908). Ājīvikas. Encyclopaedia of Religion and Ethics, 1, 259-268.

Jacobi, H. (1895). Introduction. In M. Müller (Ed.), Jaina Sūtras II. Sacred books of the east (Vol. 45, pp. i-xlii). Oxford: Oxford University Press.

Jacobi, H. (1906). Eine Jaina Dogmatik. Umāsvāti’s Tattvārthādhigama Sūtra. Übersetzt und erläutert. Zeitschrift der Deutschen Morgenländischen Gesellschaft, 60, 287-325, 512-551.

Jacobsen, K. A. (Ed.) (2012). Yoga powers: Extraordinary Capacities attained through meditation and concentration. Leiden: Brill.

Jain, J. C. (1947). Life in ancient India as depicted in the Jain Canons. Bombay: New Book Company. Jain, S. A. (1960/1992). Reality. English translation of Srimat Pujyapadacharya's Sarvarthasiddhi by S.A. Jain. Madras: Jwalamalini Trust.

Jain, P. S. (1999). Jain Literature and Philosophy: A Critical Approach. Varanasi: Pārśvanātha Vidyāpītha.

Jaini, P. S. (1978/2000). Amrtacandra Sūri's exposition on reality (Abridged version of the Introduction to Amṛtacandra Sūri's Laghutattvasphoța). In Collected papers on Jaina studies (pp. 39-82). Delhi: Motilal Banarsidas.

Jaini, P. S. (1979). The Jaina path of purification. Berkeley: University of California Press.

Jaini, P. S. (1985). The pure and the auspicious in the Jaina tradition. In J. B. Carman \& F. A. Marglin (Eds.), Purity and auspiciousness in Indian Society (pp. 84-93). Leiden: E. J. Brill.

Jaini, P. S. (2007). A note on micchāditthi in Mahāvamsa 25.110. The Journal of the Pali Text Society, 29, $153-168$ 
Jhaveri, I. H. (1990). The Sā̇nkhyā-Yoga and the Jain Theories of Parināma. Ahmedabad: Gujarat University.

Johnson, H. M. (1931-1962). See TŚPC.

Johnson, W. J. (1995). Harmless souls. Karmic bondage and religious change in Early Jainism with special reference to Umāsvāti and Kundakunda. Delhi: Motilal Banarsidas.

Kapferer, B. (1997). The feast of the sorcerer: Practices of consciousness and power. Chicago: Chigaco University Press.

Krick, H. (1982). Das Ritual der Feuergründung (Agnyādheya). Herausgegeben von Gerhard Oberhammer. Veröffentlichungen der Kommission für Sprachen und Kulturen Südasiens 16. Wien: Verlag der Österreichischen Akademie der Wissenschaften.

Laidlaw, J. (1995). Riches and renunciation: Religion, economy, and society among the Jains. Oxford: Clarendon Press.

Lalwani, K. C. (1973-1985). Sudharma Svāmi’s Bhagavatī Sūtra, Vols. I-IV [Śataka 1-12]. Prakrit Text with English Translation and notes based on the commentary of Abhayadeva Sūri. Calcutta: Jain Bhawan.

Laughlin, J. C. (2003). Ārādhakamūrti/Adhișthāyakamūrti-Popular piety, politics, and the Medieval Jain Temple Portrait. Bern: Peter Lang.

Leumann, E. (1833/1966). Das Aupapātika-Sūtra, erstes Upānga der Jaina. I. Theil. Einleitung, Text und Glossar. Abhandlungen für die Kunde des Morgenlandes VIII, 2. Hrsg. von der Deutschen Morgenländischen Gesellschaft. Nachdruck. Nedeln (Lichtenstein).

Leumann, E. (1885a). Beziehungen der Jaina-Literatur zu anderen Literaturkreisen Indiens. Actes du Sixième Congrès International des Orientalistes, Tenu en 1883 à Leide (pp. 469-564). Troisième Partie, Section 2: Aryenne. Leide: E.J. Brill.

Leumann, E. (1885b). Die alten Berichte von den Schismen der Jaina. Indische Studien, 17, 91-135.

Leumann, E. (1934). Übersicht über die Āvaśyaka Literatur. Aus dem Nachlass herausgegeben von Walther Schubring. Alt- und Neuindische Studien 4. Hamburg: De Gruyter (English translation An Outline of the Āvaśyaka Literature by G. Baumann, Introductory Essay by N. Balbir. Ahmedabad: L.D. Institute, 2010).

Luhmann, N. (1962). Funktion und Kausalität. Kölner Zeitschrift für Soziologie und Sozialpsychologie, 14, 617-644. (Reprinted from: Soziologische Aufklärung 1, pp. 12-38. Opladen: Westdeutscher Verlag, 1970.)

Luhmann, N. (1987). Distinctions directrices. Über Codierung von Semantiken. Soziologische Aufklärung 4: Beiträge zur funktionalen Differenzierung der Gesellschaft. Opladen: Westdeutscher Verlag. 1987, pp. 13-31 (English in: Theories of distinction: Redescribing the descriptions of modernity. Edited with an Introduction by W. Rasch. Translations by J. O'Neil, E. Schreiber, K. Behnke, \& W. Whobrey, 2002, Stanford: Stanford University Press).

Magnone, P. (1993). The Development of 'Tejas' from the Vedas to the Purānas. Wiener Zeitschrift für die Kunde Südasiens 36 (Suppl.), 137-147.

Magnone, P. (2009a). Patterns of Tejas (and Kșamā) in the Epics. In R. Goldman \& M. Tokunaga (Eds.), Epic Undertakings, Papers of the 12th World Sanskrit Conference. Vol. 2 (pp. 283-307). Delhi: Motilal Banarsidas.

Magnone, P. (2009b). Tejas (and Śakti) Mythologemes in the Purānas. In P. Koskikallio (Ed.), Parallels and Comparisons. Proceedings of the Fourth Dubrovnik International Conference on the Sanskrit Epics and Purānas. September 2005, Zagreb (pp. 235-256). Zagreb: Croatian Academy of Sciences and Arts.

Mahāprajña, Ā. See ViyBh.

Malde, S. (2010). The concept of Leśyā in Jaina Literature. M.A. dissertation, SOAS, London.

Mālvaṇiyā, D. D. (1971). Introduction. In M. Punyavijaya, D. Mālvaṇiyā, \& A. M. Bhojak (Eds.), Paṇnavañāsuttam. Jaina-Āgama-Series No. 9, Part 2 (pp. 201-487). Bombay: Mahāvīra Jaina Vidyālaya.

McDermott, J. P. (1975). The Kathāvatthu Kamma Debates. Journal of the American Oriental Society, 95(3), 424-433.

McDermott, J. P. (1976). Is there group Karma in Theravāda Buddhism? Numen, 23, 67-79.

Mehta, M. L., \& Chandra, K. R. (1970-1972). Prakrit Proper Names (Vols. I-II). Ahmedabad: L.D. Institute.

Mette, A. (2010). Erlösungslehre der Jains: Legenden, Parabeln, Erzählungen. Berlin: Verlag der Weltreligionen im Insel Verlag.

Monier-Williams, M. (1899/1986). A Sanskrit-English dictionary. Etymologically and Philologically Arranged. With Special Reference to Cognate Indo-European Languages. New Edition, greatly 
enlarged and improved with the collaboration of E. Leumann \& C. Cappeller and other scholars. (Reprint, New Delhi: Marwah Publications.)

Norman, K. R. (1991/1993). Observations on the dates of the Jina and the Buddha. In Collected papers (Vol. IV, pp. 185-201). Oxford: Pali Text Society.

Oberhammer, G., Prets, E., \& Prandstetter, J. (1991, 1996, 2006). Terminologie der frühen philosophischen Scholastik in Indien. Band 1-3. Wien: Verlag der Österreichischen Akademie der Wissenschaften.

Oberlies, T. (2006). Vom 'Stoff’ der Körper der Götter. Wiener Zeitschrift für die Kunde Südasiens 50, $177-197$.

Ohira, S. (1978-1980). 978-1980). Evolution of the Jaina theory of Leśyā. Jain Journal, 13-14, 119-126.

Ohira, S. (1994). A study of the Bhagavatīsūtra: A chronological analysis. Ahmedabad: Prakrit Text Society.

Oldenberg H. (1894/1917). Die Religion des Veda. Zweite Auflage. Stuttgart lin: J. G.Cottaische Buchhandlung Nachfolge (The religion of the Veda. Translated by S. B. Shrotri: Delhi: Motilal Banarsidas 1988).

Olivelle, P. (1996/2008). Introduction. Upaniṣads. A new translation by P. Olivelle, pp. i-lx. Oxford: Oxford University Press.

Parry, J. P. (1982). Sacrificial death and the necrophagous ascetic. In M. Bloch \& J. Parry (Eds.), Death and the regeneration of life (pp. 74-110). Cambridge: Cambridge University Press.

Potter, K. H. (1964). The naturalistic principle of Karma. Philosophy East and West, 14, 39-50.

Potter, K. H. (2001). How many Karma theories are there? Journal of Indian Philosophy, 29, 231-239.

Priest, G., \& Routley, R. (1989). First historical introduction: A preliminary history of paraconsistent and dialethic approaches. In G. Priest, R. Routley, \& J. Norman (Eds.), Paraconsistent logic: Essays on the inconsistent (pp. 3-75). München: Philosophia Verlag.

Punyavijaya, M., Mālvaniyā, D., \& Bhojak, A. M. (1968). Introduction. In NS 1 Part I, 1-127.

Qvarnström, O. (2003). See: YŚ (Introduction and footnotes).

Ratnacandra, M. (comp.). (1923/1988). An illustrated Ardha Magadhi dictionary. With Sanskrit, Gujarati, Hindi and English Equivalents, References to the texts and copious quotations (Vols. I-V). Delhi: Motilal Banarsidas.

Sañghavī, S., \& Dośí, B. (1932/1952). Prastāvan. In STP 2 , 1-192.

Sanghavī, S., \& Dośī, B. (1939/2000). Introduction. In $\mathrm{STP}_{3}, 1-162$.

Schmithausen, L. (1991). The problem of the sentience of plants in earliest Buddhism. Studia Philologica Buddhica Monograph Series VI. Tokyo: The International Institute for Buddhist Studies.

Schrader, F. O. (1902). Über den Stand der indischen Philosophie zur Zeit Mahāvīras und Buddhas. Leipzig: Harrassowitz.

Schubring, W. (1935). Eine alte Aufgabe der Jaina-Forschung. Forschungen und Fortschritte, 11, 20-21, 266-268 (Reprint: Kleine Schriften. Hg. K. Bruhn, 1977, pp. 311-313, Wiesbaden: Franz Steiner Verlag).

Schubring, W. (1954). Review: A. L. Basham, history and doctrines of the Ājīvikas. Zeitschrift der Deutschen Morgenländischen Gesellschaft, 104, 256-263 (Reprint: Kleine Schriften. Hg. Klaus Bruhn, 1977, pp. 468-475. Wiesbaden: Franz Steiner Verlag).

Schubring, W. (1957). Kundakunda echt und unecht. Zeitschrift der Deutschen Morgenländischen Gesellschaft, 107, 537-574.

Schubring, W. (2004). Worte Mahāvīras: Kritische Übersetzungen aus dem Kanon der Jaina. Göttingen, 1926 (Mahāvīra's Words. Translated from the German with much Added Material by W. Bollée \& J. Soni. Ahmedabad: L. D. Institute.

Sețh, H. T. (1928/1986). Pāia-Sadda-Mahaṇnavo. Dillī: Motīlāl Banārsīdās.

Sikdar, J. C. (1964). Studies in the Bhagawatīsūtra. Vaishali: Research Institute of Prakrit, Jainology \& Ahimsa.

Sikdar, J. C. (1980). Jaina Alchemy. Indian Journal of History of Science, 15(1), 6-17.

Strong, J. S. (2004). The relics of the Buddha. Princeton: Princeton University Press.

Tambiah, S. J. (1976/1977). World conqueror and world renouncer: A study of Buddhism and polity in Thailand against a historical background. Cambridge: Cambridge University Press.

Tambiah, S. J. (1984). The Buddhist Saints of the forest and the Cult of Amulets. Cambridge: Cambridge University Press.

Tatia, N. (1951). Studies in Jaina Philosophy. Varanasi: Jain Cultural Research Society.

Tsuchihashi, K. (1983). On the literal meaning of Leśya. Indologica Taurinensia, 11, 195-202.

Tulsī, Ā. (Vācanā Pramukha), \& Mahāprajña, Ā., (Pradhāna Sampādaka). (1996). Śrī Bhikṣu Āgama Viṣaya Kośa 1. (Pañc Āgamom - Āvaśyaka, Daśavaikālika, Uttarādhyayana, Nandī aur Anuyo- 
gadvāra tathā unke Vyākhyā-Granthom ke Ādhār par). Nirdeśana: Muni Dulaharāja \& Satya Rañjan Banarjī. Saṃgrahạ̣a/Anuvādana/Sampādana: Sādhvī Vimalaprajñā \& Sādhvī Siddhaprajñā. Lādnūm: Jain Viśva Bhāratī.

Tulsī, 育. (Vācanā Pramukha), \& Mahāprajña, Ā., (Pradhāna Sampādaka). (2005). Śrī Bhikșu Āgama Viṣaya Kośa 2. (Pañc Āgama- Ācāracūlā, Niśītha, Daśā, Kalpa aur Vyavahāra tathā inke VyākhyāGranthom ke Ādhār par). Nirdeśana: 'Āgam Manīṣ̂̀ Muni Dulaharāja. Saṃgrahana / Anuvādana / Sampādana: Sādhvī Vimalaprajñā \& Sādhvī Siddhaprajñā. Lạ̣̄nūṃ: Jain Viśva Bhāratī.

Tulsī, Ā. (Synod Chief), \& Mahāprajña, Ā., (Lexicographer) (2009). Jaina Pāribhāșika śabdakośa: Dictionary of Technical Terms of Jainism. Edited by Sādhvī Viśrutvibhā. Translated from the Original Hindi by Muni Mahendra Kumār. Ladnun: Jain Vishva Bharati va Bharati University.

Upadhye, A. N. (1935). Introduction. Śr̄ Kundakundācārya's Pravacanasāra (Pavayanasāra). A procanonical text of the Jainas. (Second revised edition, i-cxxvi). Bombay: Sheth Manilal Revashankar Jhaveri (Rāyacandra-Jaina-Śāstra-Mālā 9, 1930).

Upadhye, A. N. (1936). Jainism and Karma Doctrine. The Jaina Antiquary, 2(1), 1-28.

Upadhye, A. N. (1974). More light on the Yāpanīya Sanigha. Annals of the Bhandarkar Oriental Research Institute, 55, 1-4, 9-22. (Reprint from: Upadhye: Papers, 1983, pp. 192-201, Mysore: University of Mysore.)

Vijayarājendrasūri, Muni (comp.). (1913-1925/1986). Abhidhānarājendra Koṣa. Dvitīya Saṃskaraṇa (7 Vols.). Ahmadābād: Abhidhāna Rājendra Koṣa Prakāśana Saṃsthā.

Weber, A. (1865-1866). Über ein Fragment der Bhagavatī. Ein Beitrag zur Kenntnis der heiligen Sprache und Literatur der Jaina. Aus den Abhandlungen der Preussischen Akademie der Wissenschaften zu Berlin. Erster Theil \& Zweiter Theil. Berlin: Königliche Akademie der Wissenschaften, 1866-1867.

Werner, K. (1988). Indian concepts of human personality in relation to the doctrine of the soul. Journal of the Royal Asiatic Society, 1, 73-97.

Werner, K. (1996). Indian conceptions of human personality. Asian Philosophy, 6(2), 93-107.

White, D. (1996). The alchemical body: Siddha traditions in Medieval India. Chicago: University of Chicago Press.

Wiley, K. L. (2000a). Aghātiyā Karmas: Agents of embodiment in Jainism. Doctoral Dissertation, Berkeley, University of California.

Wiley, K. L. (2000b). Colors of the soul: By-products of activity or passions? Philosophy East and West, $50(3), 348-366$.

Wiley, K. L. (2012). Supernatural powers and their attainment in Jainism. In K. A. Jacobsen (Ed.), Yoga powers: Extraordinary capacities attained through meditation and concentration (pp. 145-94). Leiden: Brill.

Williams, R. H. B. (1963/1983). Jaina Yoga. A survey of the Medieval Śrāvakācāras. London: Oxford University Press. 